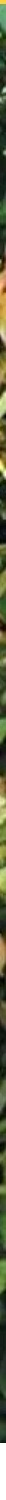

\title{
Lessons for REDD+ from measures to control illegal logging in Indonesia
}

Cecilia Luttrell

Krystof Obidzinski

Maria Brockhaus

Efrian Muharrom

Elena Petkova

Andrew Wardell

James Halperin

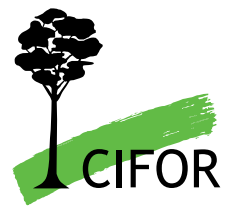



Working Paper 74

\title{
Lessons for REDD+ from measures to control illegal logging in Indonesia
}

\author{
Cecilia Luttrell \\ Krystof Obidzinski \\ Maria Brockhaus \\ Efrian Muharrom \\ Elena Petkova \\ Andrew Wardell \\ James Halperin
}


Working Paper 74

(C) 2011 United Nations Office on Drugs and Crime and Center for International Forestry Research All rights reserved

Luttrell, C., Obidzinski, K., Brockhaus, M., Muharrom, E., Petkova, E., Wardell, A. and Halperin, J. 2011 Lessons for REDD+ from measures to control illegal logging in Indonesia. United Nations Office on Drugs and Crime and Center for International Forestry Research, Jakarta and Bogor, Indonesia

Cover photo $\odot$ UNODC Indonesia

\author{
CIFOR \\ Jl. CIFOR, Situ Gede \\ Bogor Barat 16115 \\ Indonesia \\ $\mathrm{T}+62$ (251) 8622-622 \\ $\mathrm{F}+62$ (251) 8622-100 \\ E cifor@cgiar.org
}

www.cifor.cgiar.org

Any views expressed in this publication are those of the authors. They do not necessarily represent the views of CIFOR, the United Nations Office on Drugs and Crime, the authors' institutions or the financial sponsors of this publication. 


\title{
Table of contents
}

\author{
Abbreviations and glossary
}

Acknowledgements

1 Background 1

2 The illegal logging context $\quad 3$

2.1 The drivers of illegal logging 4

2.2 Overview of policies and measures to tackle illegal logging 6

2.3 Government regulations and moratoria $\quad 8$

2.4 Plantation development to bridge the supply-demand gap 9

2.5 Certification 11

2.6 FLEGT and the VPA 12

3 The REDD+ context in relation to illegal logging $\quad 14$

3.1 Specific REDD+ policies, measures and initiatives 17

4 MRV for domestic legitimacy and international credibility $\quad 21$

4.1 Clarifying the institutional framework: Data challenges 22

4.2 The ' $V$ ' in MRV 28

4.3 Ensuring access to information $\quad 34$

4.4 Matching MRV system design to available capacity 36

4.5 Avoiding unintended impacts 39

5 Multi-stakeholder process and ownership $\quad 41$

5.1 Addressing sovereignty concerns $\quad 41$

5.2 Pitching incentives at the right level: Incentivising local government 42

5.3 Getting buy-in from the private sector 44

5.4 The design and role of consultation processes 46

6 Addressing underlying governance issues

6.1 The missing role of government: A necessary part of independence?

6.2 Tackling drivers head-on or side-stepping reform? 53

7 Cross-cutting issues for FLEGT and REDD+ in tackling illegal logging in Indonesia 56

7.1 Broad governance challenges 56

$\begin{array}{lll}7.2 & \text { Law enforcement } & 57\end{array}$

7.3 Challenges in monitoring, reporting and verification 58

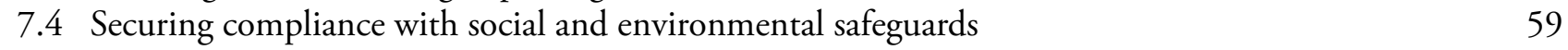

7.5 Access to information $\quad 59$

$\begin{array}{ll}7.6 & \text { Institutional reforms and capacity } \\ 7.7 & \text { Engendering ownership }\end{array}$

$\begin{array}{lll}7.7 & \text { Engendering ownership } & 61\end{array}$

8 Key lessons learned $\quad 63$

$\begin{array}{ll}\text { References } & 65\end{array}$

$\begin{array}{ll}\text { Annex. Consultation meeting participants } & 77\end{array}$ 


\section{List of tables, figures and boxes}

\section{Tables}

1. Estimates of illegal logging in Indonesia from 5 supply-demand analyses 3

2. Illegal logging cases in Indonesian courts, 2005-2009 7

3. Timber plantation establishment in Indonesia, 2000-2008 11

\section{Figures}

1. REDD+ dynamics in Indonesia 18

2. Institutional set-up of Indonesia's TLAS, or SVLK (from GoI and EU 2011c) 30

\section{Boxes}

1. Estimates of Indonesian state revenue losses due to illegal logging 4

2. Details of the SVLK 13

3. The Letter of Intent between Indonesia and Norway 20

4. Principles listed in the REDD+ Strategy 21

5. Contested data: Illegal logging estimates 23

6. Data needed for MRV of carbon emissions for REDD+ 24

7. Recent data collation initiatives 26

8. Credibility problems with previous timber control and verification systems in Indonesia 30

9. Forms of independent monitoring for legality verification under the VPA 32

10. The complaint system for the SVLK 33

11. Examples of transparency in the SVLK

12. Barriers to getting convictions in high-level illegal logging cases: An example 38

13. Complementarities and contrasts between international and national MRV needs 39

14. Use of multi stakeholder processes in the development of legality standards 46

15. Agreed principles for the VPA $\quad 48$ 


\section{Abbreviations and glossary}

\begin{tabular}{|c|c|}
\hline AMDAL & Analisis mengenai Dampak Lingkungan (Environmental Impact Assessment) \\
\hline APL & Area penggunaan lain (other land use) \\
\hline Bakosurtanal & $\begin{array}{l}\text { Badan Koordinasi Survei dan Pemetaan Nasional (National Coordinating Agency for Survey } \\
\text { and Mapping) }\end{array}$ \\
\hline Baplan & Badan Planologi (Ministry of Forestry Planning Agency) \\
\hline Bappenas & Badan Perencanaan Pembangunan Nasional (National Development Planning Agency) \\
\hline $\mathrm{BIG}$ & Badan Informasi Geospasial (formerly Bakosurtanal; Geospatial Information Agency) \\
\hline BPK & Badan Pemeriksa Keuangan (Supreme Audit Board) \\
\hline BPS & Badan Pusat Statistik (Central Statistics Agency) \\
\hline BRIK & Badan Revitalisasi Industri Kehutanan (Timber Industry Revitalization Body) \\
\hline BUK & Bina Usaha Kehutanan (Forestry Business Unit) \\
\hline $\mathrm{CAB}$ & Conformity Assessment Body \\
\hline CAR & Corrective Action Request \\
\hline CCBA & Climate, Community and Biodiversity Alliance \\
\hline CDM & Clean Development Mechanism \\
\hline CIFOR & Center for International Forestry Research \\
\hline $\mathrm{CO}_{2}$ & Carbon dioxide \\
\hline $\mathrm{CoC}$ & Chain of custody \\
\hline $\mathrm{COP}$ & Conference of the Parties to the UNFCCC \\
\hline CSF & Civil Society Forum for Climate Justice \\
\hline $\mathrm{CSO}$ & Civil society organisation \\
\hline CSR & Corporate social responsibility \\
\hline DA & Demonstration activity \\
\hline DNPI & Dewan Nasional Perubahan Iklim (National Climate Change Council) \\
\hline DR & Dana Reboisasi (Reforestation Fund) \\
\hline $\mathrm{EC}$ & European Commission \\
\hline EIA & Environmental Impact Assessment \\
\hline ERC & Ecosystem Restoration Certificate \\
\hline $\mathrm{EU}$ & European Union \\
\hline $\mathrm{FAO}$ & Food and Agriculture Organization of the United Nations \\
\hline FCPF & Forest Carbon Partnership Facility (World Bank) \\
\hline FIP & Forest Investment Program \\
\hline FLEGT & Forest Law Enforcement, Governance and Trade \\
\hline FMU & Forest management unit \\
\hline FOMAS & Forest Resource Management System \\
\hline FORDA & Forest Research and Development Agency (Ministry of Forestry) \\
\hline FPIC & Free and prior informed consent \\
\hline
\end{tabular}


FRIS

FSC

FWI

GDP

GFTN

GHG

GIS

GoI

$\mathrm{HPH}$

$\mathrm{HPHH}$

HPK

HTI

HTR

IFCA

IMF

INCAS

IPHHK

IPK

IPKMA

ITTO

IUPHHK

IUPJL

JIC

JKPP

JPIK

KAN

KPK

LAPAN

LEI

LoI

LPI

LULUCF

MFP

$\mathrm{MoE}$

$\mathrm{MoF}$

Monev

$\mathrm{MoU}$

MRV

MSP

NAMA

NGO
Forest Resource Information System

Forest Stewardship Council

Forest Watch Indonesia

Gross domestic product

Global Forest Trade Network

Greenhouse gas

Geographic Information System

Government of Indonesia

Hak Pengusahaan Hutan (forest concession right)

Hak Pemungutan Hasil Hutan (forest harvest rights)

Hutan Produksi Konversi (conversion production forest)

Hutan Tanaman Industri (industrial timber plantation)

Hutan Tanaman Rakyat (community plantation forest)

Indonesia Forest Climate Alliance

International Monetary Fund

Indonesia National Carbon Accounting System

Industri Primer Hasil Hutan Kayu (wood-processing industries)

Ijin Pemanfaatan Kayu (permit for conversion of forest to other uses)

Ijin Pemanfaatan Kayu Masyarakat Adat (provincial community-logging licences)

International Tropical Timber Organization

Izin Usaha Pemanfaatan Hasil Hutan Kayu (Logging Concession Permit)

Izin Usaha Pemanfaatan Jasa Lingkungan (Environmental Services Use Permit)

Joint Implementation Committee

Jaringan Kerja Pemetaan Partisipatif (Participatory Mapping Network)

Jaringan Pemantau Independen Kehutanan (Independent Forest Monitoring Network)

Komisi Akreditasi Nasional (National Accreditation Committee)

Komisi Pemberantasan Korupsi (Corruption Eradication Commission)

Lembaga Penerbangan dan Antariksa Nasional (National Space Agency)

Lembaga Ekolabel Indonesia (Indonesian Eco-labeling Institute)

Letter of Intent (Indonesia-Norway)

Lembaga Penilai Independen (Independent Assessment Body)

land use, land use change and forestry

Multi-stakeholder Forestry Programme

Ministry of Environment (Indonesian Government)

Ministry of Forestry (Indonesian Government)

Monitoring and evaluation

Memorandum of Understanding

Monitoring, reporting and verification

Multi-stakeholder process

Nationally Appropriate Mitigation Actions

Nongovernmental organisation 
OHL

Operasi Hutan Lestari (Sustainable Forest Operation)

Permenhut Peraturan Menteri Kehutanan (Ministry of Forestry Regulation)

PHPL

Pengelolaan Hutan Produksi Lestari (Sustainable Production Forest Management)

PSDH

Provisi Sumber Daya Hutan (Volume-Based Tax on Timber Harvesting)

PUHH

Ministry of Forestry's Timber Administration System

REDD+

Reducing emissions from deforestation and forest degradation

REL

Reference emissions level

RKTN

National-Level Forestry Plan 2011-2030 (Indonesia)

RPJMN

National Medium-Term Development Plan (Indonesia)

RPJPN

National Long-Term Development Plan 2005-2025

R-PP

Readiness Preparation Proposal

RTRWP

Rencana Tata Ruang Wilayah Provinsi (Provincial Spatial Planning Process)

SBSTA

Subsidiary Body for Scientific and Technological Advice

SFM

SVLK

TLAS

Sustainable Forest Management

TNC

Sistem Verifikasi Legalitas Kayu (Timber Legality Verification System)

TPTI

UKP4

UN

Timber Legality Assurance System

The Nature Conservancy

Tebang Pilih Tanam Indonesia (Selective Logging and Planting System of Indonesia)

Unit Kerja Presiden bidang Pengawasan dan Pengendalian Pembangunan (President's Work Unit for Development Monitoring and Control)

UNDP

United Nations

UNEP

United Nations Development Programme

UNFCCC

United Nations Environment Programme

UNODC

United Nations Framework Convention on Climate Change

UN-REDD

VCS

VCU

United Nations Office on Drugs and Crime

United Nations Collaborative Programme on Reducing Emissions from Deforestation and Forest Degradation in Developing Countries

VPA

Walhi

Voluntary Carbon Standard

Voluntary Carbon Unit

Voluntary Partnership Agreement

WGCC

Indonesian Forum for Environment

Working Group on Climate Change 


\section{Acknowledgements}

The authors are indebted to a number of people who provided input and assistance for the working paper. We thank all the participants (see Annex) who attended the consultation meeting held 17 May 2011, as well as Ajit Joy, Andy Roby, Mardi Minang and Faith Doherty, who met with us and provided information, comments and valuable material. Alison Hoare, David Brown and Jade Saunders also provided discussion and material. We are also grateful to Anna Sinaga, Ahmad Dermawan and Bart van Assen for their input. We thank Imogen Badgery-Parker for her thorough editing of the final draft, and Gideon Suharyanto and his publishing team for typesetting and final preparation of the text. We are also grateful to two anonymous reviewers.

This working paper was prepared for the Indonesia office of the United Nations Office on Drugs and Crime. CIFOR would like to thank the Royal Norwegian Embassy in Jakarta for their financial support for this report. 


\section{Background}

\section{What lessons for the ongoing design of REDD+ mechanisms, processes and institutions in Indonesia can be learnt from experience with measures to combat illegal logging in Indonesia?}

Indonesia has committed to reducing its emissions from land use, land use change and forestry (LULUCF) by $26 \%$ by 2020 (GoI 2010). One way the country plans to meet this target is by reducing its emissions from deforestation and forest degradation through the REDD+ mechanism. By implementing REDD+, Indonesia will become eligible to receive financial payments based on forest carbon credits. A substantial amount of Indonesia's carbon emissions are caused by deforestation and forest degradation from land conversion activities, forest fires and illegal logging, with the latter having significant impacts as a driver of deforestation. Therefore, initiatives to curb illegal logging will have to form a central part of any emission reduction strategy. REDD+ has the potential to help reduce illegal logging activities by creating financial incentives to encourage compliance with the law, changes in behaviour and wider governance reforms.

Since 2001, several initiatives in Indonesia have attempted to address the problem of illegal logging. These include international initiatives such as the Forest Law Enforcement, Governance and Trade (FLEGT) process; bilateral agreements between Indonesia and major importers of timber; and market instruments such as timber certification. National initiatives include joint security sweeps (Operasi Hutan Lestari or OHL, sustainable forest operation) to combat illegal logging, anti-money laundering approaches to tackle illegal finance in the sector and the expansion of timber plantations to increase the supply of timber.

This working paper explores ways in which the ongoing design of REDD+ mechanisms and institutions can benefit from these experiences. The authors obtained their data through literature reviews, press/media reviews and selected stakeholder interviews.
This working paper focuses primarily on the FLEGT-VPA (Voluntary Partnership Agreement), and the associated SVLK (Sistem Verifikasi Legalitas Kayu, or timber legality verification standards), as a trade-related measure, and on enforcement measures such as the OHL. In doing so, it explores some of the key differences and similarities between FLEGT and REDD+. FLEGT aims to ensure that timber is produced in accordance with the laws of a country, using access to the international market as an incentive. REDD+ aims to create performancebased monetary incentives to halt deforestation and forest degradation. Obtaining REDD+ finance will require attention to aspects such as credibility, traceability and social and governance safeguards as well as independent verification. The SVLK has had to develop mechanisms to address all these aspects. Therefore, its lessons are likely to be relevant to REDD+ and there may be opportunities for synergies between the systems and the ways in which they have dealt with these concerns. The REDD+ and FLEGT processes are both nationally designed mechanisms that require implementation at the local level. This raises the question of how these processes can design incentive structures given the ongoing decentralisation reforms in Indonesia in order to ensure subnational ownership. Lessons from the OHLs are also useful in examining this issue.

Lessons from illegal logging measures can be divided into process lessons and outcome lessons. Process lessons examine how the mechanism was designed and implemented. Outcome lessons consider the impact that such measures have, or can have, in tackling deforestation, forest degradation and the underlying governance causes. In terms of process, several pertinent aspects of the design of the SVLK mirror the concerns raised in current discussions on the design of REDD+ institutions and systems. The SVLK was initially developed in a context where the existing forest control system was perceived as lacking the independence and transparency needed for international credibility. Much of the design has focused on ways to address these deficits. In terms of outcomes, it is too early to make firm conclusions 
about the impact of the existing processes. For example, bilateral arrangements between Indonesia and timber-purchasing countries helped to raise awareness about problems with the illegal logging trade in consumer countries and provided significant resources for capacity building in Indonesia.

However, it is not clear to what extent they actually helped reduce the illegal timber trade. For this reason, much of the emphasis in this paper is on process. However, we do explore some issues in terms of their potential ability to tackle governance aspects and conclude with a discussion of the degree to which we can expect the measures to be able to resolve more deep-seated governance issues.

The working paper is structured as follows. Section 2 discusses the Indonesian context of illegal logging and various measures taken over the years to control it (including FLEGT). Section 3 introduces the REDD+ context and explains its relationship with efforts to combat illegal logging; current REDD+ policies and initiatives in Indonesia are presented in detail in Section 3.1. Section 4 discusses monitoring, reporting and verification (MRV) systems focusing on concerns of institutional design issues such as the need for clear standards, independent verification, transparency and the inclusion of safeguards. Section 5 focuses on process issues, including how to ensure ownership and multi-stakeholder engagement in the process. Section 6 explores the degree to which these processes can address fundamental underlying governance issues. Section 7 distils the main crosscutting issues for tackling illegal logging and the implementation of REDD+ in Indonesia, and the working paper ends with a summary of the key messages and recommendations. 


\section{The illegal logging context}

Despite some evidence that it might be declining, illegal logging remains a major driver of deforestation and forest degradation in Indonesia. Illegal logging covers a range of activities and occurs at several stages along the supply chain.

Illegal logging is one of the major drivers of deforestation in Indonesia (Schloenhardt 2008); it also contributes greatly to forest degradation. Although illegal logging emerged as a threat to Indonesia's forests in the late 1990s, national forestry statistics suggest it had been occurring since at least the mid-1980s (World Bank 2006). 'Illegal logging' refers to a range of activities at many stages along the supply chain:

- Illegal felling of timber in both production and conservation forest zones. For example, in production forest areas, logging companies often extract timber illegally by felling trees outside their allocated blocks, by harvesting timber in volumes that exceed their authorised amounts (WWF/World Bank Alliance 2005) or by taking out more undersized and oversized trees than permitted.
- Cutting of protected tree species or extraction of trees from a protected area.

- Illegal excision of land from the forest estate for mining or oil palm plantations.

- Lack of due process in obtaining or allocating licences.

- Non-payment or underpayment of taxes.

- Illegal processing and illegal export by using forged documents to transport the timber (see UNODC 2010).

- Fraudulent declarations to customs of the amount or the dimensions of timber products being exported.

EIA/Telapak (2002: 2) estimate that in 2001, 73\% of logging in Indonesia was illegal. A more recent estimate suggests that $76 \%$ of the annual timber production comes from illegal sources (Stark and Cheung 2006: 31, 39). These figures cannot be verified, but there appears to be consensus amongst most sources that illegal logging accounts for more than $40 \%$ of Indonesia's total wood supply, with many reports suggesting that the volume of illegal

Table 1. Estimates of illegal logging in Indonesia from 5 supply-demand analyses

\begin{tabular}{|c|c|c|c|c|c|}
\hline Issues & $\begin{array}{l}\text { Scotland et al. } \\
1999\end{array}$ & $\begin{array}{l}\text { Brown et al. } \\
2005\end{array}$ & $\begin{array}{l}\text { Manurung et al. } \\
2007\end{array}$ & Tacconi 2007 & $\begin{array}{l}\text { Human Rights } \\
\text { Watch } 2009\end{array}$ \\
\hline Timeframe & 1997-1998 & $2006-2025$ & 1980-2005 & 2000,2003 & 2003-2006 \\
\hline Data sources & $\begin{array}{l}\mathrm{MoF}^{\mathrm{a}}, \mathrm{APKI}^{\mathrm{b}}, \mathrm{BPS}^{\mathrm{c}} \text {, } \\
\text { own estimates }\end{array}$ & $\begin{array}{l}\text { MoF, own } \\
\text { estimates }\end{array}$ & $\mathrm{FAO}^{\mathrm{d}}, \mathrm{MoF}, \mathrm{APKI}$ & $\begin{array}{l}\text { FAO, MoF, own } \\
\text { estimates }\end{array}$ & MoF, ITTOe \\
\hline Domestic markets & Yes & Yes & Yes & Yes & Yes \\
\hline Foreign markets & Yes & No & No & Yes & No \\
\hline $\begin{array}{l}\text { Extent of supply-demand } \\
\text { gap as a proxy for illegal } \\
\text { logging (million } \mathrm{m}^{3} \text { per year } \\
\text { for the timeframe studied*) }\end{array}$ & $41.2-56.6$ & $25-30$ & $4.0-42.2$ & $19.1-24.0$ & 20.045 .0 \\
\hline \multicolumn{6}{|l|}{ a Ministry of Forestry } \\
\hline \multicolumn{6}{|c|}{ b Asosiasi Pulp dan Kertas Indonesia (Indonesian Pulp and Paper Association) } \\
\hline \multicolumn{6}{|c|}{ c Badan Pusat Statistik (Central Statistics Agency) } \\
\hline \multicolumn{6}{|c|}{ d Food and Agriculture Organization of the UN } \\
\hline \multicolumn{6}{|c|}{ e International Tropical Timber Organization } \\
\hline * Note: None of these figures cap & ures small-s & & & & \\
\hline
\end{tabular}


logging exceeds legal production. As a review of various estimates shows (Table 1), estimates of the volume of illegal logging range from 4 million to 56.6 million $\mathrm{m}^{3}$ per year.

Some recent analyses suggest that there has been a clear decline in illegal logging in Indonesia since 2003, due to greater international scrutiny, improved forest law enforcement and growing market demand for legal timber products (Lawson and MacFaul $\left.2010^{1}\right)$. However, the extent of this decline is not clear, even though log smuggling to China is said to have fallen by $92 \%$ since 2004 (Lawson and MacFaul 2010). It is important to keep in mind that statistics do not capture the whole supply-demand gap. Existing supply-demand assessments in Indonesia are based on official statistics that register large and medium-sized wood-based industries and do not account for small-scale operations and informal trade. Therefore, considerable uncertainty is involved in estimating the scale of illegal logging.

In terms of a monetary valuation of illegal logging, estimates range from US\$600 million to US\$8.7 billion per year (Box 1). It is interesting to compare these figures with official figures on legal production. In 2007, the total official value of the output generated by forest industries was Rp 27.2 trillion (about US $\$ 3$ billion) or $1.4 \%$ of Indonesia’s gross domestic product (GDP) (MoF 2009). The forestry sector also contributes to export earnings: the timber and pulp and paper sectors generated US\$7.5 billion in 2007 , or $8 \%$ of all export earnings excluding oil and gas (Bank of Indonesia 2010). However, the forestry sector's relative contribution to GDP and export earnings has been declining, although it remains significant in absolute terms. Indonesia's reliance on the export of natural resources continues to underpin the economy (Gellert 2010). This has led to highly uneven benefits and significant loss of control and livelihood opportunities for people living in and around forested land, as well as conversion of forestland to other uses. However, as the relative importance of the forestry sector declines, so too does the level of illegal logging. Nevertheless, some areas, such as the 'new frontier' of Papua, offer great

1 There has been some discussion and critique of the results and methods of this report. See, for example, http://www.wri. org/stories/2011/01/year-illegal-logging-look-back.

\section{Box 1. Estimates of Indonesian state revenue losses due to illegal logging}

Human Rights Watch (2009) estimates that the Indonesian government lost US\$2 billion in 2006 due to illegal logging, corruption and mismanagement. This amount included forest taxes and royalties not collected on illegally harvested timber; shortfalls due to unacknowledged subsidies to the forestry industry (including basing taxes on artificially low market prices and exchange rates); and losses from tax evasion by exporters practising 'transfer pricing'. The figure does not include losses from smuggling, from evasion of other taxes such as income tax or from taxes that were assessed on legal wood but never actually collected. Further, the calculation of losses from illegal logging by the Ministry of Forestry does not include a significant portion of the country's sawmill industry, as mills with processing capacities of less than $6000 \mathrm{~m}^{3}$ per year are not required to report their wood consumption to the ministry. Mills with smaller capacity are thought to be oriented towards local consumption.

Others estimate that illegal logging in Indonesia causes between US\$600 million and US\$3 billion in financial losses to the Indonesian government each year (Seneca Creek 2004: 73-74). The US Department of Agriculture Foreign Agricultural Service (2004) reports that the total loss annually is US\$5.7 billion, including ' $\$ 4.08$ billion from the price of logs and $\$ 1.63$ billion losses from unpaid taxes and fees'. Indonesian government estimates from 2002 (reported in Brack et al. 2002) put the cost at US\$3 billion/year. However, as Seneca Creek (2004: 73) points out, none of the estimates is based on hard data or is detailed enough to associate volumes or percentages with specific types of illegal practices.

potential for illegal extraction of timber, and policies encouraging rapid investment in plantations provide new opportunities for established interest groups to continue business-as-usual illegal logging practices.

\subsection{The drivers of illegal logging}

The gap between supply and demand is one of the most significant structural causes of illegal logging. The supply-demand gap has 3 main causes: smallscale trade and subsistence; demand by woodprocessing industries for the domestic market; and demand by international markets. 
The gap between the high demand for forest products and the limited available supply is considered to be the main structural cause of illegal logging in Indonesia (Barr 2001, Brown et al. 2005). This supply and demand gap has 3 main dimensions: (1) small-scale trade and subsistence; (2) demand by wood-processing industries for the domestic market; and (3) demand by international markets. Although it is possible to estimate the scale of illegal logging associated with industry and international market demand, illicit practices associated with local subsistence and small-scale domestic trade remain completely outside national statistics. The high and rising - demand coincides with diminishing supplies of timber from natural forest and the lagging development of timber plantations.

The origins of much illegal logging associated with industrial production can be traced back to the uncontrolled expansion of timber-processing industries (especially plywood mills) in the 1980s and the subsidised promotion of pulp and paper mills in the 1990s. This policy shift led to an expansion of the wood-processing capacity and succeeded in making Indonesia a leading producer and exporter of tropical plywood. However, it was not accompanied by measures that would have ensured legal and sustainable supplies of raw timber (Barr 2001). As mills began to multiply, their growth outpaced the available supply from logging concessions (HPH; Hak Pengusahaan Hutan), and the Ministry of Forestry (MoF) never managed to control the widening gap. The timber supply problem worsened in the mid-1990s with the expansion of the pulp and paper industry, as none of the mills possessed productive timber plantations. In the mid-1980s, the MoF had introduced the industrial timber plantation programme (HTI; Hutan Tanaman Industri) with the aim of ensuring a sustainable future source of timber for wood-processing industries. However, the implementation of this programme lagged from the start and did not make significant progress until the late 1990s (Barr 2001, Barr et al. 2010).

Huge demand on regional and global markets also fuels illicit practices. For example, European traders are increasingly outsourcing to Asia as a way of cutting costs (UNODC 2010: 162). The outsourcing makes the supply chain more complex, with illegally sourced timber changing hands more often. According to a 2008 assessment, as much as $40 \%$ of the wood-based products imported into the EU from Southeast Asia were illegal, with Indonesia as the primary source. Indonesian timber is often trans-shipped from China and falsely said to come from Malaysia (WWF 2005, 2008, Obidzinski $e t$ al. 2006a, 2006b). Other transit routes are via the Philippines, Papua New Guinea, Singapore and Malaysia (UNODC 2010: 165).

Illegal logging also occurs in the form of extracting wood for domestic consumption (Klassen 2010). During periods of high economic growth, demand for (notably) construction timber is high; the timber is often supplied through informal networks involving tens of thousands of rural producers. Given Indonesia's large population and associated local demand for timber, there are thousands of small-scale timber operations. Klassen (2010) estimates that up to 10 million $\mathrm{m}^{3}$ of timber is illegally extracted in Indonesia for domestic consumption. There are also indications that the domestic construction industry is a significant market.

Although sectors such as furniture making are labour intensive and provide incomes for many people (Purnomo et al. 2009), forestry policymakers have traditionally focused on larger-scale industry (such as the plywood and pulp and paper sectors), which are export oriented. Several factors encourage the bias towards export-oriented industries and facilitate national policies to continue to allow forest clearance in order to generate the necessary timber supplies. These factors include the perceived strategic importance of pulp and paper within the forestry sector, the government's desire to reinstate Indonesia as the world's leading tropical timber producer, vested interests in maintaining business as usual and the awareness that the production capacity of existing timber plantations falls far short of the volumes of timber needed (Obidzinski and Chaudhury 2009).

This attitude was reflected in the process of drafting the Presidential Instruction to facilitate the implementation of a logging moratorium (as part of the Letter of Intent (LoI) between Indonesia and Norway on REDD+; see Box 3). Stakeholders involved in drafting the moratorium held differing opinions on the scope of the logging moratorium and whether it should be limited to primary forest and 
peatland areas or expanded to cover secondary forest; whether or not it should cover the whole country; and whether it should apply to mining in forests as well as logging. The MoF pushed for the instrument not to cover secondary forests; the Presidential Instruction to implement the moratorium, No. 10/2011 (issued in May 2011), applies to peatland and primary forest only.

\subsection{Overview of policies and measures to tackle illegal logging}

Several policy measures and incentives have been introduced over the years to curb illegal logging and trade. These range from market-based initiatives to regulatory/enforcement measures, including measures that involve both market and enforcement mechanisms such as FLEGT-VPA.

During the past decade, the government of Indonesia has taken a number of direct measures to curb illegal logging. These measures include intensifying forest law enforcement operations, signing Memoranda of Understanding (MoUs) with key timber-importing countries, listing illegal logging as a predicate crime under anti-money laundering legislation, seeking to boost forest certification and engaging in the FLEGT process leading towards a VPA with the EU (Tacconi et al. 2004, Setiono and Hussein 2005, Jurgens 2006). Although some progress appears to have been made, the extent of recent declines in illegal logging is uncertain because estimates and statistical sources vary widely. At the same time, other policies that have indirectly encouraged illegal logging practices, such as tax breaks for timber removed from conversion areas and new wood-processing capacity, have continued (see, for example, Brown 1999).

The first FLEG meeting focusing specifically on illegal logging was held in Bali in 2001. The main objective of the FLEG initiative, supported by FAO and the World Bank, was to raise awareness amongst government decision-makers of the extent, nature and implications of forest crimes, including illegal logging. It began by informing national-level decision-makers in major timber-producing countries about the dangers of illegal logging, with subsequent regional processes established for Africa, Europe and Latin America, as well as Asia. Follow-up FLEG processes in Jakarta in 2003 resulted in concerted efforts to improve the effectiveness of conventional law enforcement.

The intensification of law enforcement ran parallel to the revision of certain decentralisation regulations in the forestry sector in place since 1999 that had been identified as providing opportunities for illegal or opportunistic behaviour. Thus, regulations allowing districts and provinces to issue small-scale logging permits were repealed. In addition, the log export ban, which had been in place from 1985 to 1997 , was reintroduced in 2001 (FWI 2003).

Significant intensification of measures to combat illegal logging has been observable since 2005 . Several factors contribute to this. Increasing public scrutiny, pressure by international NGOs on Indonesian markets abroad and the growing spectre of trade difficulties due to calls for certification and legality audits - especially in the EU - gradually built up and could no longer be ignored. Indonesia was increasingly being criticised for forest destruction linked to illegal logging (see, for example, FWI and GFW 2002) and prominent campaigns included ground-level monitoring by the NGO alliance EIA/ Telapak and efforts to pressure European buyers by Friends of the Earth and Greenpeace (through reports such as 'Partners in Crime'; Greenpeace 2005). Indonesia developed a reputation as a highrisk country for sourcing forest products. ${ }^{2}$ These campaigns prompted buyers to improve their sourcing processes, and some of Indonesia's main European buyers including the UK reformed their public procurement policies (Brown et al. 2008: 175). The following sections summarise the policies and measures for tackling illegal logging that have been introduced during the past decade.

\subsubsection{Bilateral agreements}

The FLEGT process was followed by bilateral agreements between Indonesia and major timberimporting countries to more closely monitor timber traffic between the origin and destination points in order to root out illegal practices. Beginning in 2002, Indonesia signed a series of MoUs with key timber-importing countries to coordinate the movement of timber and improve the exchange of

2 More recent reports suggest that these concerns are still being voiced (see, for example, Human Rights Watch 2009). 
information on timber shipments. For example, an $\mathrm{MoU}$ with the UK on measures to tackle illegal logging pioneered work to formulate a standard for legal compliance. Equivalent MoUs were developed with other consumer countries, including the USA, along with policy work facilitated by the World Bank on '10 steps' for the effective prevention, detection and suppression of illegal logging. Collaboration agreements to limit illegal trade of timber were also signed with Malaysia, China and Japan (Tacconi et al. 2004, Jurgens 2006). These initiatives came largely as a result of reports by TRAFFIC and the International Tropical Timber Organization (ITTO) of large discrepancies between the volumes of timber dispatched from Indonesia and the volumes reported upon arrival at their destinations, especially China, the EU and the USA (CINTRAFOR 2002).

These MoUs helped to expose the problem of the illegal timber trade between Indonesia and major timber-importing countries and created an arena for cooperation and capacity building in Indonesia. However, the extent to which they actually helped reduce the illegal timber trade is unclear. Many of these MoUs only existed on paper and none of them progressed to the point of setting up concrete monitoring systems (Jurgens 2006).

\subsubsection{Law enforcement measures}

Attention to law enforcement has increased dramatically since 2005. Arguably, the tipping point in the illegal logging debate occurred following the release of a report in that year by EIA/Telapak, an NGO alliance, exposing massive timber-smuggling operations from Papua Province to China (EIA/ Telapak 2005). In the aftermath of this report, Indonesia's President issued a Presidential Decree (Presidential Instruction No. 4/2005) mandating coordinated law enforcement sweeps (between the $\mathrm{MoF}$ and the police) across Indonesia. The OHLs (Operasi Hutan Lestari; sustainable forest operations) were annual enforcement operations targeting illegal logging in the main timber-producing regions (Detik News 2005). The draft illegal logging law (which is still before Parliament) that resulted from the 2005 Presidential Decree may provide a stronger legal foundation for Indonesia's efforts to curb illegal logging. One point of contention with this law, however, is the degree to which it transfers authority to the police away from the MoF.

Other law enforcement measures include the increased use of the court system. During the past 5 years, it appears that the number of illegal logging cases has declined and the ratio of convictions has increased (Table 2); importantly, these include some high-profile cases, mostly in the context of corruption. Whilst this trend represents an encouraging development, doubts persist as whether it reflects genuine improvement in law enforcement, or simply whether fewer cases are being brought to court. Jakarta-based think-tank Greenomics has criticised these figures because they refer only to the recorded illegal logging cases (Antara 2010). Greenomics claims that many illegal logging cases never make it to official registers as they are settled 'amicably'. More recently, in April 2010, President Susilo Bambang Yudhoyono, apparently frustrated

Table 2. Illegal logging cases in Indonesian courts, 2005-2009

\begin{tabular}{lccccccc}
\hline Year & Number of cases & \multicolumn{5}{c}{ Progression of cases through the judicial system } \\
\cline { 3 - 7 } & & $\begin{array}{l}\text { Preliminary } \\
\text { investigation }\end{array}$ & Full investigation & SP3 $^{\text {a }}$ & P21 $^{\text {b }}$ & Trial & Convictions \\
\cline { 3 - 8 } & 720 & 15 & 705 & 25 & 438 & 281 & 245 \\
2005 & 1714 & 142 & 1572 & 18 & 699 & 389 & 304 \\
2007 & 478 & 114 & 364 & 2 & 249 & 198 & 152 \\
2008 & 177 & 44 & 133 & 1 & 82 & 40 & 31 \\
2009 & 107 & 27 & 80 & 1 & 41 & 26 & 13 \\
\hline
\end{tabular}

a Warrant to stop the investigation

b Investigation completed

Source: Ministry of Forestry (2009) 
by the lack of progress in prosecuting illegal logging cases through the courts, ordered his government's task force on eradication of the judicial mafia to investigate.

The combination of these efforts indicates a high level of political commitment. Nevertheless, these measures, as we discuss later in the working paper, have some limitations. For example, although the OHL resulted in reduced smuggling in major timber hubs, some observers claim the joint enforcement sweeps were of limited success because timber and equipment seizures rarely, if ever, led to the recovery of state financial losses: 'Some ascribe OHL as an approach to political pressure to deliver prosecutions, as opposed to any serious interest in tackling the root causes of illegal logging' (Wells et al. 2007). The success of OHL operations to a significant degree depended on close cooperation of 18 government agencies, as stipulated in the Presidential Decree of 2005 aimed at tackling illegal logging. However, entrenched vested interests and protection of sectoral turf prevented this cooperation from being effective.

\subsubsection{Anti-money laundering legislation and anti-corruption initiatives}

The introduction of the 2003 anti-money laundering law (revised in 2010), under which illegal logging was made a predicate crime, was another significant step because it brought illegal logging under the purview of the banking sector and anti-corruption authorities. Other relevant initiatives include the role of anti-corruption agencies (Hartoyo 2011, Santoso et al. 2011), Customer Due Diligence and Enhanced Due Diligence by banks and fiscal policy reforms. ${ }^{3}$ These initiatives represent a new approach to combating illegal logging by following the money rather than the logs. As many perpetrators and financiers of illegal logging cannot be directly linked to timber extraction activities on the ground, it was hoped that this legislation would make it easier to catch the 'masterminds' behind illegal logging, who remained largely untouchable within the scope of conventional law enforcement, which tends to net the 'smaller fish'.

In relation to this, the KPK (Komisi Pemberantasan Korupsi; Corruption Eradication Commission) has

3 See Dermawan et al. (2011) for a more detailed discussion on anti-money laundering laws and related initiatives. started to recover financial losses incurred by the state (Jasin 2010). One breakthrough case is that of Marthias, who was charged with corruption in the forestry sector. He was sentenced to 18 months' imprisonment and had to return Rp 346 billion (US\$35.4 million) to the state. ${ }^{4} \mathrm{~A}$ parallel case was that of Suwarna Abdul Fatah, former governor of East Kalimantan Province, who was charged with receiving bribes from Marthias and was sentenced to 4 years in prison. ${ }^{5}$

However, realising the full potential of anti-money laundering legislation to combat illegal logging has proven difficult and the tools remain underused. Few prosecutions have been made under the legislation, mainly because of the complexities of defining and monitoring suspicious financial transactions and linking them to illegal logging offences. Other factors are the secrecy of banking operations, the reluctance of the police to use the new legislation, the limited capacity of law enforcement agencies and law courts and the lack of cooperation amongst law enforcement agencies.

\subsection{Government regulations and moratoria ${ }^{6}$}

Indonesian governments have introduced several regulations designed to control illegal logging, such as moratoria on logging, log export bans and sanctions for companies that exceed their authorised harvesting limits. A national log export ban was reintroduced in 2001 (FWI 2003) following a previous log ban that had been in place between 1985 and 1997, which aimed to addressing public criticism of unsustainable logging and develop a domestic plywood industry (Gellert 2003). In 2007, the province of Aceh introduced a ban on logging and forest conversion designed to safeguard the unique ecosystem of Leuser National Park, to position itself in anticipation of carbon funds and to prevent a repeat of the flooding associated with the 2004 tsunami (Jakarta Post 2007). A logging ban is often seen as a radical, lastditch effort to limit the damage from logging in

\footnotetext{
4 Court decision No. 21/PID.B/TPK/2006/PN.JKT.PST on Marthias.

5 Court decision No. 380.K/Pid. Sus/2007 on Suwarna.

6 CIFOR is currently compiling additional information on earlier efforts to use moratoria in Indonesia.
} 
conditions where nothing short of a blanket ban is expected to produce results.

There has been no comprehensive analysis examining the effectiveness of this moratorium for preserving forest cover. However, anecdotal reports indicate the moratorium has been only partly effective. Illegal logging continues to be a problem (Jakarta Post 2009) and processing industries continue to use illegal timber. Attempts to develop roads, oil palm estates and industrial timber plantations at the expense of the forest are continuing (Analisa 2011). Wibowo (2011) suggests that the impacts of moratoria are unproven; indeed, his research in Kerinci Sebelat, Sumatra, suggests that population pressure, demand for agricultural land, failure to safeguard protected areas and the dynamics of agricultural prices can undermine logging bans. A further risk of a national logging moratorium is that the forestry sector may 'slide' further into illegality in order to fill the supply-demand gap (MacDicken 2010).

The objective of the log export moratorium introduced in Papua in 2009 differed from the Aceh policy, but the outcomes have been similarly limited (Jakarta Post 2008). The export ban in Papua stipulated that all logs were to be processed locally in order to limit extraction, encourage development of local industries and contribute value-added to the provincial economy. In addition, the conversion of forest was to be radically curtailed - all in anticipation of REDD+ projects and carbon funds (Butler 2008). As in Aceh, the ban has only partly achieved its objectives. The level of timber extraction did fall, as more than half of the logging concessions were inactive for other reasons such as administrative and financial problems or social conflict with local communities, or because companies acquire some concessions for speculation only. However, it is not clear why the ban failed to achieve its objectives. Reports indicate continued smuggling of logs or roughly sawn timber out of Papua (EIA/Telapak 2010). Often logs sourced in Papua Province are passed off as logs from West Papua Province, where shipping of unprocessed timber to other parts of the country is still legal. The Papuan government has had some success with limiting the extent of the forest that can be legally converted to plantations. However, large-scale plantation and agro-food projects (e.g. the Merauke Integrated Food and Energy Estate (MIFEE) for good crops and palm oil) continue to be developed.

In 2004, the MoF issued a letter of instruction to impose a national-level moratorium on natural forest conversion by pulp and paper companies by 2009 in order to force them to develop industrial timber plantations (MoF 2004). However, the order was swiftly revoked and the moratorium postponed until 2014 (Down to Earth 2009a). In May 2011, a 2-year moratorium under the Norwegian LoI was announced, requiring that both legal and illegal logging activities in designated areas in Indonesia be stopped. However, as discussed above, the experience with previous moratoria is not encouraging. A review by Maryudi in Cashore et al. (2010: 474) suggests that government regulations such as moratoria have had limited effectiveness because of their 'underdeveloped and even counter-productive regulatory frameworks', lack of enforcement and 'corruption and collusion among forestry officials and within other state agencies'.

\subsection{Plantation development to bridge the supply-demand gap}

The measures outlined above do not necessarily directly address the crucial issue of closing the supply-demand gap in the wood-processing sector. In this respect, the accelerated development of timber plantations to produce sufficient supplies of timber has become the government's strategy of choice. Less attention is being paid to industrial restructuring and reducing excess capacity in the processing industry. The government assumes that industrial capacity is being reduced through closures of ply mills as they go out of business. However, an analysis of wood consumption shows that consumption still exceeds the legally available supply (Human Rights Watch 2009).

Indonesia has a long history of timber plantation development for industrial purposes and for rehabilitation of degraded land. Large-scale timber plantation development began in the mid-1980s in recognition of expanding industrial demand for wood fibre and limited supply of timber from natural forests (Guizol and Aruan 2004). During the following 2 decades, Indonesia embarked 
on extensive timber plantation development programmes dominated by large-scale plantations (Hutan Tanaman Industri, HTI).

In 2006, the MoF announced plans to accelerate the development of timber plantations as part of its long-term strategic plan for 2006-2025 (MoF 2006). Under this new policy, the government would establish 9 million ha of new timber plantations by 2016 (Sinar Harapan 2006, AgroIndonesia 2007a). Of this total, approximately 5.4 million ha was to be smallholder community ventures called HTR (Hutan Tanaman Rakyat, community plantation forest). The remaining 3.6 million ha was earmarked for development as HTI (AgroIndonesia 2007b, 2007c, Sugiharto 2007a, 2007b, 2007c).

The main component of this new policy, HTR, was originally planned for 102 districts in 8 provinces in Kalimantan and Sumatra (MoF 2007a), but it was soon thereafter extended to all of Indonesia (Sugiharto 2007d, 2007e). For the initial phase from 2007 to 2010 , the Indonesian government planned to allocate up to 1.4 million ha of land annually to approximately 90000 families throughout the country. The policy proposed to have 5.4 million ha of land allocated by 2010, and 1.97 million ha planted. It was expected that, once productive, these new plantations could produce enough raw materials not only to bridge the current supply-demand gap but also to spur growth in the timber industry (Kompas 2006).

However, nearly 4 years after implementation, the ministry has approved only a few HTR applications. Communities are objecting to the design of HTR projects because of limited tenure incentives, difficult application processes and complicated procedures to secure funding (Obidzinski and Dermawan 2010). Perhaps the greatest weakness of the HTR programme is the limited economic appeal $^{7}$ of growing trees for household incomes in Indonesia. Overall, fast-growing timber is far less profitable than other crops such as oil palm or rubber. As a result, the HTR programme has so far met with lack-lustre responses from provinces,

7 Notable examples to the contrary do exist. For example, research by CIFOR in smallholder teak plantations in Java has shown that the sector can provide up to $27 \%$ of household incomes (Irawati et al. 2009). districts and communities and is unlikely to perform better unless operationalisation of HTR licences is made easier, tenure incentives are introduced and intercropping with other cash crops is allowed. The main problem with the current timber plantation policy is that perverse incentives exist to acquire forestland for logging, whilst the safeguards to ensure appropriate implementation and sustainability of planting are weak.

Despite the lack of success with HTR plantations, the MoF claims to have made major progress with large-scale industrial timber plantations (Table 3). According to official statistics, by 2008 the cumulative area of timber plantations had reached 4.3 million ha, producing 22.3 million $\mathrm{m}^{3}$ of timber (MoF 2009, Verchot et al. 2010). However, the accuracy and veracity of these data have been questioned, especially the sudden increase in HTI timber production in 2007 and 2008. Some observers of Indonesia's timber plantation sector state that the number of plantation estates actually producing timber may be less than half of the officially quoted figures (Sugiharto 2007f). World Bank analysts in Jakarta are even more skeptical and suggest the area of productive HTI plantations may be no more than one-third of the officially quoted numbers (World Bank 2006:77).

Illegal logging measures such as strengthening enforcement and trade-related measures such as FLEGT-VPA will not necessarily directly address the crucial issue of closing the supply-demand gap in the wood-processing sector. REDD+ has the potential to reverse this trend by providing meaningful financial incentives to plant trees on degraded, non-forested land to produce timber. REDD+ could involve activities such as the intensification of plantation production methods or provision of incentives for the development of plantations outside high carbon-stock forests on degraded lands. REDD + could also facilitate restoration of carbon stocks in degraded forest areas through restoration concessions (IUHPPK-RE). In theory, REDD+ projects featuring timber plantations on degraded land could improve the returns, providing an incentive for legally compliant plantation operations and reducing the pressure on natural forests. However, practical experience from former and ongoing plantation 
Table 3. Timber plantation establishment in Indonesia, 2000-2008

\begin{tabular}{cccc}
\hline & $\begin{array}{c}\text { Log supply from } \\
\text { timber plantations }\left(\mathbf{m}^{3}\right)\end{array}$ & $\begin{array}{c}\text { Timber plantation } \\
\text { development }(\text { ha) }\end{array}$ & $\begin{array}{c}\text { Cumulative area } \\
(\text { ha) }\end{array}$ \\
\hline 2000 & 3783604 & 82317 & 2500583 \\
2001 & 5567282 & 67472 & 2568055 \\
2002 & 4242532 & 118508 & 2686563 \\
2003 & 5325772 & 124691 & 2811254 \\
2004 & 7329028 & 131914 & 2943168 \\
2005 & 12818199 & 163125 & 3106293 \\
2006 & 11451249 & 231954 & 3338247 \\
2007 & 20614209 & 334839 & 3673085 \\
2008 & 22321885 & 291984 & 3965069 \\
\hline
\end{tabular}

Source: Ministry of Forestry (various years)

initiatives in Indonesia is not positive. The poor outcome of the HTR programme is a case in point.

If the development of timber plantations is to become a REDD+ activity, many issues concerning the use of degraded land for plantation development remain to be addressed. First, there is a need to clarify the definitions, criteria and indicators associated with degraded land in Indonesia. Second, the poor quality of data on the location of degraded land contributes to uncertainty about its characteristics and availability, with consequent disputes over its use. The complexity of managing degraded lands that are already occupied by hundreds of thousands of spontaneous settlers increases the inherent risks and costs of trying to resolve multiple claims to the same land, on top of the of the complexity of the task of resettling these people. Third, the economic rationale for using degraded land for plantations must be made clear and convincing (Elson 2011). For example, with non-degraded lands, there are advantages in offsetting early investment costs and maintaining cash flows by harvesting any standing timber before converting the land to other uses. Furthermore, the extent to which the requirement for larger inputs due to poor soil condition will increase the costs of plantation development on degraded lands is not clear. Fourth, there is a need for specific information about the level of technical inputs (fertiliser, energy, other chemical compounds) that will not contravene carbon additionality. Fifth, many degraded land areas are inhabited or under some form of agro-management; this raises questions about how plantations can be developed in such areas in a socially and economically appropriate manner.

\subsection{Certification}

During the past decade, NGO campaigns in and about Indonesia have had an important role in creating the momentum that led to a push for certification and a range of private sector trade initiatives with their own standards for verification of legal origin and legal compliance (Brown et al. 2008: 176). This push coincided with rising demand for certified and legally verified timber to be traded from Indonesia to EU countries, the USA and Australia. The certification drive was spearheaded by international NGOs such as WWF, which introduced a step-wise approach for certifying Indonesian timber producers under its Global Forest Trade Network (GFTN).

WWF and other organisations seeking to prepare logging companies for certification, such as Tropical Forest Trust (TFT) and Tropical Forest Foundation (TFF), all use the Forest Stewardship Council (FSC) certification standard, which is the most broadly accepted timber sustainability standard in major timber markets (Jurgens 2006). However, progress with certification in Indonesia has been slow.

To date, FSC has certified 1.1 million ha of natural forest managed by 8 concessionaires in Indonesia. Only 4 of these concessions are in $\mathrm{HPH}$; the other 4 are community-managed teak plantations, including 
about 704000 ha of timber plantations and 25000 ha of community forest (see www.lei.or.id). The majority of the operators certified are wood processing factories in Java, many of them furniture makers. Although this comprises a sizeable area, these numbers, which are the result of several years' work, constitute only a small fraction of the overall forest production estate in Indonesia. There are indications that more logging concessions are on the verge of entering the FSC certification process. If so, this would signal progress toward much awaited forest certification in Indonesia.

At the same time, 156 timber processors have received FSC chain of custody $(\mathrm{CoC})$ certificates (http://info.fsc.org/). Although this may seem a significant achievement, the number of certified concessionaires has remained unchanged during the past few years and most $\mathrm{CoC}$ certificates have been granted to small-scale timber-processing operators, mainly in Java.

As progress with certification in Indonesia continued to be slow and FSC was the leading accepted standard for the sustainability and legality of timber traded internationally, some people at the $\mathrm{MoF}$ and within the Indonesian forestry NGO community began to see FSC as a barrier to progress. In response to this sentiment, the Indonesian Ecolabeling Institute (Lembaga Ekolabel Indonesia; LEI) was formed with the intention that it would eventually develop its own standard, which would be compatible with FSC and acceptable internationally. LEI and FSC have had a rocky relationship and present a mixed record. LEI initially collaborated with FSC, seeking to certify Indonesian timber producers using the FSC standard. Eventually, it developed its own standard but, given the perception that some principles had been diluted and the resulting incompatibility with FSC, the collaboration broke down. In June 2010, LEI and FSC decided to work together again, agreeing to an 18-month $\mathrm{MoU}$ during which time both organisations would explore ways to overcome differences and find synergies (FSC 2010).

\subsection{FLEGT and the VPA}

The most recent development in the fight against illegal logging in Indonesia is the signing in May
2011 of the bilateral VPA (Voluntary Partnership Agreement) between the EU and Indonesia, designed to ensure the legality of timber traded from Indonesia to European markets. The VPAs are the culmination of the FLEGT Action Plan, which was initiated by the EC in 2003 in response to the illegal logging crisis in tropical forested countries. The FLEGT Action Plan recognises the fact that the EU is one of the largest consumers of timber in the world, and that a significant portion of this timber (especially tropical timber) comes from supplier countries with serious illegality and other governance problems (EC 2003). FLEGT was intended to provide capacitybuilding support to timber-exporting countries to address the illegality problems, offer incentives for trade in legal timber through public procurement policies and ensure that European investments in timber trade take steps to exclude illegally logged timber.

Indonesia elected to develop a VPA in 2007. However, the process stalled, particularly over the formulation of the legality standard and the requirement that it be modified to include $\mathrm{CoC}$ monitoring and independent verification. Eventually, it was agreed that the VPA with Indonesia would license timber under a national timber legality assurance system known as the SVLK (Sistem Verifikasi Legalitas Kayu). The SVLK is an integrated system that can track the movement of timber from the forest to mills and then to domestic and international markets, and involves independent auditing by ISO-accredited auditors against a legality standard (see Box 2). EU customs authorities would be responsible for preventing any unlicensed Indonesian products from entering the EU. Indonesian timber exported to the EU under VPA licensing schemes will be considered to have met the requirements of the new EU Timber Regulation, thus offering Indonesian timber preferential access to the EU market. Although VPA is an exclusive agreement between Indonesia and the EU, the advantage of signing a VPA for Indonesia is that the underlying timber legality verification system (SVLK) also meets the legality verification requirement for timber exports to the USA and other major markets. If Indonesia had chosen not to sign a VPA, exports to the EU could well have been restricted when the EU Timber Regulation comes into force in 2013. 


\section{Box 2. Details of the SVLK}

The SVLK regulations include:

- P.38/Menhut-II/2009 on Standards and Guidelines on Assessment of Performance of Sustainable Production Forest Management and Verification of Timber Legality for Licence Holders or in Private Forests, which lays out the institutional mechanisms for the SVLK and explains how the SVLK creates an internationally acceptable chain of custody

- P.06/VI.Set/2009 on Standards and General Guidelines for the SVLK

- P.02/VI-BPPHH/2010 on Technical Guidelines for Auditing Processes (including Complaint Procedures) for the SVLK

The SVLK comprises (Gol and EU 2011c):

- legality standards setting out which laws must be met, along with criteria and indicators for testing compliance with these laws;

- control of the supply chain with requirements for systems to trace wood products through the production chain from harvesting to the point of export;

- verification procedures and requirements for verification of both compliance with the legality definition and control of the supply chain;

- a licensing scheme for issuing FLEGT licences; and

- independent monitoring, comprehensive assessment and periodic auditing to increase credibility by ensuring that all requirements of the legality assurance scheme are being implemented as prescribed.

It also lays out the complaints procedure, which gives civil society the right to contest the findings of the certifying body and potentially suspend a company's timber exports.

In addition to or parallel with the VPA, many major consumer markets have passed, or are developing, additional policies or regulations aimed at excluding illegally harvested timber. The EU Timber Regulation ${ }^{8}$ adopted on 20 October 2010 and the United States' 2010 amendment to the 2008 Lacey Act prohibit the import and sale of illegally harvested timber in their countries, which together make up $50 \%$ of Indonesia's export market. The EU Timber Regulation is a market-based mechanism that requires that timber importers ensure their timber is legal when it first enters the EU market. The total average annual value of timber and paper exports from Indonesia to the EU is US $\$ 1.2$ billion, or around $15 \%$ of Indonesia's timber exports (GoI

8 The EU Timber Regulation, which will become operational in March 2013, prohibits the sale of illegally harvested timber and products manufactured from such timber. It also obliges traders that first supply timber or timber products in the EU to exercise 'due diligence' to minimise the risk of selling illegal timber (GoI and EU 2011a). Importers will therefore be accountable for the goods that they import into the EU. This legislation aims to reduce the undercutting the prices of bona fide traders by those supplying cheaper but illegally harvested timber (GoI and EU 2011a). and EU 2011a: 1). Japan's Green Purchasing Law requires that its government agencies buy legal timber products, and Australia has released draft legislation, the Illegal Logging Prohibition Bill 2011, which, if passed, will prohibit the import of regulated timber products that contain a portion of illegally logged timber. Several other countries are developing similar policies (GoI and EU 2011a).

The following sections examine key design issues that are of relevance to REDD+ in Indonesia and draw on experience from illegal logging measures to discuss what lessons can be learnt. We structure the discussion around (1) institutional design concerns for the key issue of MRV; (2) lessons related to process, in order to facilitate ownership and multistakeholder buy-in of the process; and (3) the degree to which these processes can be expected to address more fundamental governance issues. 


\section{The REDD+ context in relation to illegal logging}

The effectiveness of REDD+ will depend on each country's ability to curb or significantly reduce illegal logging activities. Most REDD+ activities - particularly those that involve addressing illegal activities - will require a wider governance approach.

The concept of reducing emissions from deforestation and forest degradation (REDD) originated from the submission of countries in the Coalition for Rainforest Nations (CRN), led by Papua New Guinea and Costa Rica, at the United Nations Framework Convention on Climate Change Conference of the Parties 11 (UNFCCC COP 11) in Montreal in 2005. The submission gained momentum at COP 13 in Bali, Indonesia, in 2007 and was formalised in 'The Bali Action Plan'. The action plan summarised REDD+ as:

Policy approaches and positive incentives on issues relating to reducing emissions from deforestation and forest degradation in developing countries; and the role of conservation, sustainable management of forests and enhancement of forest carbon stocks in developing countries. (UNFCCC 2007: 3)

The main idea of the scheme was to compensate developing countries for their efforts in avoiding deforestation and degradation. Further agreement on a performance-based REDD+ mechanism was reached at COP 15 (Copenhagen 2009) and COP 16 (Cancún 2010), but the modalities, regulations and implementation procedures are not yet clear. In the meantime, additional multilateral and bilateral initiatives on REDD+ have gained greater momentum. REDD+ is a key element in the government of Indonesia's national- and international-level commitments to address the challenges of climate change. In October 2009, President Susilo Bambang Yudhoyono announced a target of $26 \%$ emission reductions by 2020 , thus demonstrating the country's commitment to preserve its forests. By implementing REDD+, Indonesia will become eligible to receive financial payments based on carbon credits. The country is presently at the forefront of forest-rich tropical countries in preparing for the implementation of REDD+.

Estimates of the degree to which different sectors contribute to Indonesia's carbon emissions vary. A study in 2007 (PEACE et al. 2007) suggested that land use change contributes about $85 \%$ (2 $563000 \mathrm{Gg} \mathrm{CO}_{2}$ per year) of Indonesia's total annual emissions, and a study from 2008 (World Bank 2008) suggested that the mean annual $\mathrm{CO}_{2}$ emissions from land use change and forestry reached $2398000 \mathrm{Gg} \mathrm{CO}_{2}$, with $53 \%$ coming from peat fire, $20 \%$ from peat drainage, $22 \%$ from deforestation and $5 \%$ from oil palm and timber plantation establishment (MoE 2010a). By contrast, the Second National Commission (MoE 2010a) estimated that only $51 \%$ of Indonesia's annual emissions come from deforestation and land use change, whereas the Dewan Nasional Perubahan Iklim (National Climate Change Council) (DNPI 2009) stated in a press conference fact sheet that $85 \%$ of Indonesian emissions in 2005 came from agriculture, land use and land use change within the country's forest and peatland areas $\left(2.1 \mathrm{Gt} \mathrm{CO}_{2} \mathrm{e}\right)$, with $41 \%$ of its current emissions coming from peatland and $37 \%$ from forest. These figures were projected to grow by $1.9 \%$ each year, to reach $2.5 \mathrm{Gt} \mathrm{CO}_{2} \mathrm{e}$ in 2010 and $3.3 \mathrm{Gt} \mathrm{CO}_{2} \mathrm{e}$ in 2030 (DNPI 2009).

There are significant pressures on Indonesia's land use, notably land cover changes associated with the timber industry, palm oil and pulp and paper industries and large-scale biofuel plantations. However, the effectiveness of REDD+ will also depend on the country's ability to curb or significantly reduce illegal logging activities and their associated impacts on deforestation and degradation and to provide incentives for law enforcement (Angelsen 2009). Illegal logging is an important cause of deforestation and degradation, and therefore measures to address illegal logging will be of relevance for REDD+. There are a number of specific areas of complementarities; for example, sustainable forestry management (SFM) is a priority for REDD+ that can be supported by combating illegal logging. Land use 
and zoning rules and their enforcement, although not integral to either scheme, are critical for both.

One key area of overlap is governance. Governance is at the heart both of establishing a credible legal and sustainable timber industry and of developing an operational REDD+ mechanism. The success of both depends on the success of efforts to establish respect for the law; therefore, both have to address the issues of poor governance that underpin illegal logging and trade (Proforest 2011). There is, for example, a concern that without attention to governance impacts, disbursement of REDD+ finance will be risky, delayed or difficult. Ultimately, both REDD+ and trade-related mechanisms such as FLEGT-VPA rely on credibility and confidence in the market; governance is an important element in strengthening this credibility.

A clear objective of FLEGT is credibility building. It is claimed (see, for example, Saunders et al. 2008) that when illegal logging is a driver of deforestation and degradation, a combination of legality assurance and licensing systems with due diligence requirements can help to decrease the benefits of involvement in illegal logging, and thus enhance investor confidence in REDD+. However, the relationship is not always straightforward. One issue raised by Nussbaum (2010) is that although direct financial compensation can clearly address some activities relevant to REDD+ (such as low-impact logging, intensified agriculture and protection rather than conversion), many other activities, particularly those involving illegal activities, require a wider governance approach.

The main enabling governance conditions for REDD+ include the need to (1) clarify tenure and resource rights; (2) improve legal enforcement; and (3) reform and strengthen institutions. In the Indonesian context, fundamental governance issues that need to be resolved to enable successful REDD+ implementation include the following.

- Legal pluralism and significant customary and statutory tenurial uncertainties over land, forest and carbon. The lack of clear land boundaries and lack of clearly defined titles comprise major loopholes that allow room for discretionary decisions (Dermawan et al. 2011).
Failure to resolve uncertainties is problematic for benefit sharing.

- Spatial planning processes (Rencana Tata Ruang Wilayah Provinsi/RTRWP) in the context of deforestation. Attention is needed to ensure the process is better enforced, reflects the official economic and legal status of the land and is linked to wider development strategies.

- The lack of clarity in authority between decentralised levels of government and the regulatory and licensing loopholes that result from contradictory legislation. For example, despite its official powers, the MoF does not always have de facto authority over the forest estate because many local administrations continue to issue their own concession permits. In addition, local governments have considerable de jure powers to issue licences in APL (area penggunaan lain; other land use areas) and considerable influence over conversion production forest (Hutan Produksi Konversi; HPK) licences and competing land use sectors. This issue has delayed some REDD+ projects.

- Failures and lack of transparency in resource allocation, control and revenue collection (see Barr et al. 2010, Dermawan et al. 2011).

Related to these aspects are several key design issues that are dominating the current debate on REDD+. Discussion of these issues can draw directly on experience with introducing illegal logging measures in Indonesia during the past decade. The remainder of this working paper examines these (particularly FLEGT-VPA-related measures) and the lessons that can be extrapolated to address the needs of the $\mathrm{REDD}+$ process. These include the need to:

- identify the causes of deforestation and forest degradation and how they will be addressed;

- generate accurate and transparent data to support decisions (Dermawan et al. 2011);

- establish an MRV system that has national acceptance and international credibility;

- ensure transparency and publicly accessible information;

- prioritise geographical areas and activities for REDD+ to focus on; an element of this discussion is resolution of the debate over definitions of forest and degraded land and where such areas are located; 
- avoid unintended effects such as leakage into other areas caused by pilot programmes or into pressures for the increased supply of illegal wood;

- encourage coordination and alignment between ministries, decentralised levels and spatial planning processes at all levels;

- ensure that REDD+ does not distort other official processes and that its activities are synergistic with other national objectives;

- develop an enabling environment, such as necessary regulations for the private sector (and voluntary market) investment; and

- facilitate capacity building for all of the above.

FLEGT and REDD+ processes have several similarities, but also some key differences. In terms of objective, FLEGT aims to ensure that timber production takes place in accordance with the laws of a country by offering as an incentive improved access to the EU market for guaranteed legal timber. REDD+ aims to create performancebased monetary incentives to halt deforestation and forest degradation. Both involve a commodity - timber or carbon - but whereas timber has a well-established market mechanism that moves along a visible, controllable supply chain, the carbon market is emerging and is based on carbon storage. One fundamental difference is that REDD+ (through enhancing carbon storage) encompasses a global good or service, which timber is not; this has huge implications for the property rights over the commodity and benefit-sharing arrangements, and results in different incentives for 'producers' to become involved in each process. This is linked to the lack of legal clarity regarding property rights over trees and carbon stocks. Most countries have laws regulating the use of forests, but often have no clear laws (yet) on who owns the trees if they are kept standing as depositories of carbon. Tenure is a fundamental barrier in both processes; for FLEGT, this is mostly related to tree tenure (Brown 2011), whereas for REDD+, carbon rights and land rights form an important part of the complexity.

Forests contain both timber and carbon, particularly forests on peat. Well-managed legal forest production maintains both timber flows and carbon storage. Timber is an easily measurable product whose utility value comes from visible, if often remote, forests. By contrast, carbon is difficult to measure, has no intrinsic use and has a less tangible value, which is largely created by regulation or the threat of regulation. The more technical and intangible nature of carbon measurement creates a greater need for more refined MRV systems than for legality. This feature also means that public and external oversight is more problematic as monitors require higher levels of capacity. For this and other reasons, REDD+ may be even more vulnerable to corruption than timber has been (Brown 2011).

In terms of the nature of the mechanism, FLEGT is a bilateral process, whereas REDD+ is being developed under the assumption that it will be regulated under the global architecture of a UN convention (United Nations Framework Convention on Climate Change; UNFCCC). This might suggest that REDD+ is less sensitive than FLEGT to donor pressure. However, in the short term, and in the absence of an international agreement, it is operating as a fund-based mechanism with a variety of carbon markets and levies as potential future financing options. Whatever the eventual market, a key feature is that both timber and carbon markets require credibility.

The design of FLEGT assumes that markets are the primary driver of change, and that civil society has become effective at influencing these markets through targeted campaigning. The FLEGT mechanism heavily emphasises industry as a key player; this is not the case for REDD+, in which government is likely to have a more significant role, partly because of the need to address permanence and leakage concerns (Brown 2011). For this and other reasons (such as the potential size of the financial flows and the performance basis for payments), REDD+ arguably has greater potential to bring about governance reforms (Brown 2011). The governance reforms required for REDD+ must be broad and all-encompassing in scope, whereas those for illegal logging are much more specific. REDD+ is therefore more challenging and complex than FLEGT.

Both processes require cross-sectoral mechanisms and face the challenge of marrying forestry sector programmes. This need is more acute for REDD+ as the drivers are more clearly cross-sectoral. However, both processes tend to be viewed as recentralising forces, and therefore face challenges in terms of getting support at decentralised levels. 
It should be noted that many of the common requirements and synergies between illegal logging measures such as FLEGT and REDD+ are related to production, community and other forests and timber plantations, although data and similar needs are also relevant for protection and conservation forests. FLEGT-VPA systems are more limited in scope and do not apply to all forest categories, as they are concerned with verifying that timber is legally produced and that logging is banned in some forest categories. However, data and enforcement activities in all forests will support both efforts, as studies show that, in 2007, illegal logging was also taking place in Indonesia's national parks, a practice that is likely to continue (UNEP 2007).

\subsection{Specific REDD+ policies, measures and initiatives}

A number of REDD+ policies, measures and initiatives have been developed in recent years. These range from government initiatives such as consultation processes, regulatory frameworks, strategies, institutional reforms and the establishment of REDD+ pilot sites to donor-driven financing and programmes.

Since COP 13 in Bali, the Indonesian government has taken a number of steps to formulate a legal and regulatory framework related to $\mathrm{REDD}+$, involving several key processes and events (Figure 1). In this section, we provide an overview of some of the key policies, measures and initiatives.

\subsubsection{Laying the groundwork}

In mid-2007, the Indonesia Forest Climate Alliance (IFCA) was established as a governmentdevelopment agency partnership to analyse the existing legal and policy framework regulating the forestry sector and opportunities for climate-changerelated interventions. Reviews were conducted of available data on carbon stocks and land use change, priorities for action with respect to the key drivers of deforestation and degradation and mechanisms for engaging with carbon markets and managing REDD+ payments. Eight studies were collated in a key document titled 'REDD+ methodology and strategies: Summary for policy makers', presented at COP 13 in 2007.

\subsubsection{Regulatory framework}

The MoF initiated a public consultation process in June 2008 in relation to the development of ministerial regulations and institutions concerning REDD+. In December 2008, the MoF issued Regulation (Permenhut) No. P.68/Menhut-II/2008, which describes the procedure for the application and legitimisation of REDD+ demonstration activities (REDD-DA). The regulation permitted the testing and evaluation of the REDD+ methodology, technology and institutional framework (MoF 2008). This was followed by the establishment of a Working Group on Climate Change (WGCC) (SK.455/ Menhut-II/2008) and the appointment of resource persons (SK.21/Menhut-II/2009).

In 2009, the MoF issued 2 new related regulations. The first was P.30/Menhut-II/2009, which describes the implementation procedures for REDD+ and the transformation of REDD-DA into 'real' REDD+ projects. The regulation distinguishes between nationally driven and internationally driven REDD+ initiatives. It sets out requirements for project developers and implementing bodies, and for validation and verification. The second regulation was P.36/Menhut-II/2009, which covers the procedures for licensing commercial use of carbon sequestration and/or storage in production and protection forests. It differentiates between carbon absorption and sequestration activities in various types of forest and business. It also specifies how revenues generated from these are to be shared amongst stakeholders. However, the Ministry of Finance subsequently questioned the right of the $\mathrm{MoF}$ to regulate financial issues, and it is unclear whether these regulations are likely to be successfully implemented.

In addition, as part of its licensing process, the $\mathrm{MoF}$ established the IUPJL (Izin Usaha Pemanfaatan Jasa Lingkungan; Environmental Services Use Permit), a permit to use environmental services in production forests under Regulation No. 6/2007 (Articles 1 and 61, as amended by Regulation No. $3 / 2008$, Article 33). Another relevant regulation is P.50/Menhut-II/2010 on procedures on issuing and expanding IUPHHK working areas in natural forests, IUPHHK ecosystem restoration or IUPHHK-HTI for production forests. Amongst other functions, this regulation requires all REDD+ projects to 


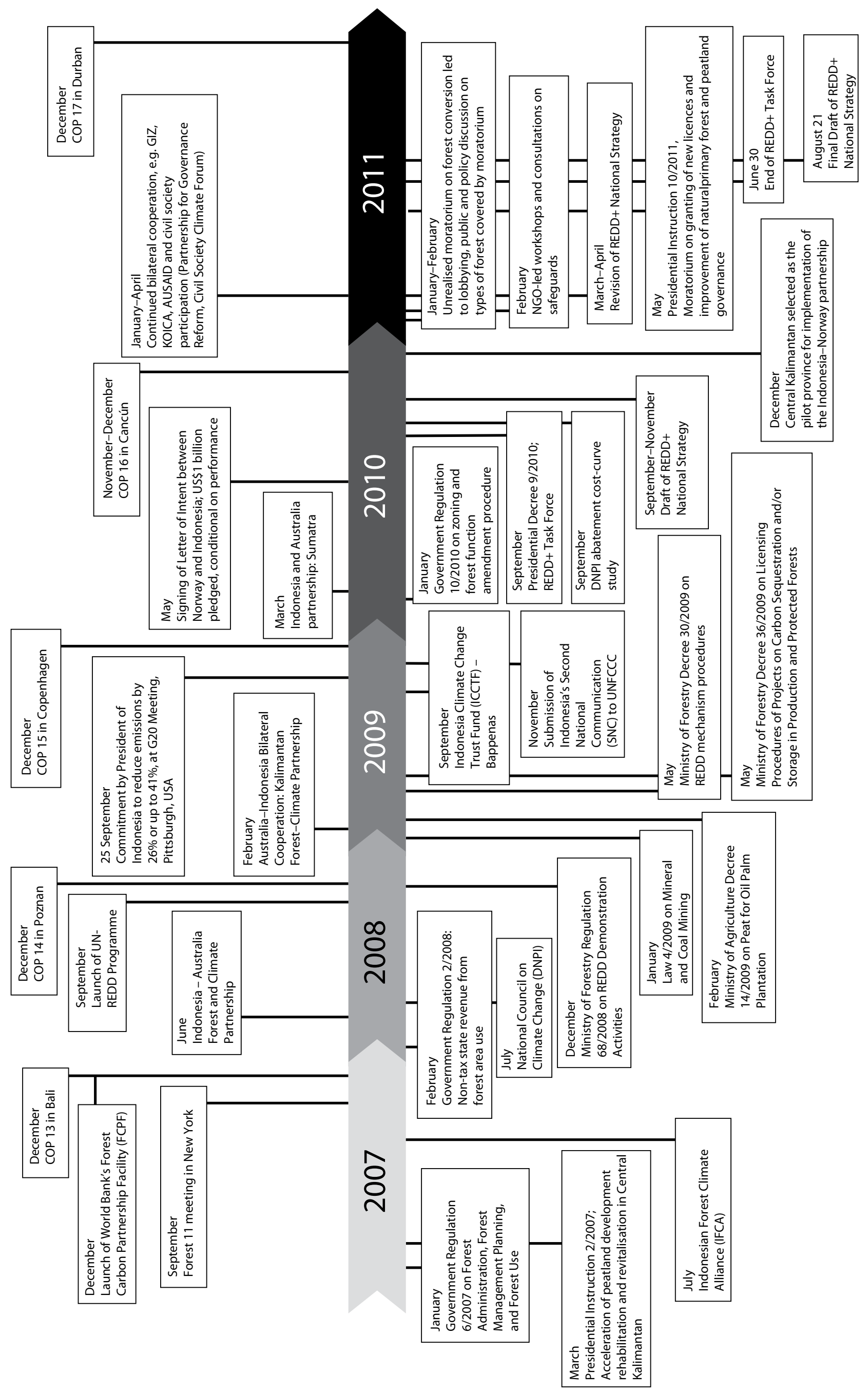


get provincial and district clearance for IUPHHK Ecosystem Restoration Concession licences and for both full and partial environmental impact assessments (EIAs).

\subsubsection{Mainstreaming REDD+}

In January 2010, the MoF, in collaboration with several funding bodies and NGOs, formulated the National Strategy of REDD+ Indonesia Readiness Phase 2009-2012 (referred to in this working paper as the MoF Readiness Plan; MoF 2010a). Under this plan, 3 implementation phases were proposed: (1) preparation: identification of information, knowledge, technology and related policies (20072008); (2) readiness: preparation of methodology and policies (2009-2012); and (3) full implementation: implementation according to COP regulations in the post-2012 UNFCCC scheme.

On 24 September 2010, the National Development Planning Agency (Bappenas) presented a draft of the National Strategy for the Reduction of Emissions from Deforestation and Forest Degradation (or the REDD+ Strategy; GoI 2010, 2011). It is intended that the strategy will form part of the National Medium-Term Development Plan (RPJMN) 2010-2014, the National Long-Term Development Plan (RPJPN) 2005-2025 and the National-Level Forestry Plan (RKTN) 2011-2030 (GoI 2010). The strategy will then be defined as the National Action Plan (RAB REDD+) and serve as the working document for ministries and regional governments to formulate, implement, monitor and evaluate programmes and activities to reduce emissions from the forestry and land use management sector (GoI 2010). In March 2011, an expert team was formed to produce a second draft of the strategy based on feedback from public consultation. ${ }^{9}$

\subsubsection{Institutional reforms}

The 2007 COP 13 negotiations, hosted by Indonesia, and the subsequent Bali Road Map gave impetus for President Susilo Bambang Yudhoyono to establish a National Climate Change Council (Dewan Nasional Perubahan Iklim; DNPI) (under Presidential Regulation No. 46/2008) to coordinate the

9 The second draft is currently under revision. An unofficial version is available at http://www.scaleup.or.id/ articles/Article-2011/070411-Draft\%202\%20Stranas\%20 REDD+_30Mar2011.pdf (in Indonesian). government's response to climate change mitigation and adaptation. The council is chaired by the President and has 18 state institutions as its members; its mandate is to coordinate the national focal point for the UNFCCC (Article 2 of the decree). The function of the DNPI is to coordinate activities related to adaptation, mitigation, technology transfer and funding.

Several other actors, with their own related strategies and mandates, have emerged as part of the more recent institutional REDD+ landscape in Indonesia. These include the MoF with its REDD+ Commission specifically mandated to manage the implementation of REDD+, Bappenas with its leadership of the REDD+ Strategy development process, the Ministry of Finance and, more recently, UKP4 (Unit Kerja Presiden bidang Pengawasan dan Pengendalian Pembangunan; the President's Work Unit for Development Monitoring and Control) and the REDD+ Task Force, which is leading commitments under the LoI. The REDD+ Task Force has been tasked under the LoI with setting up an independent MRV institution and with designing and establishing a funding instrument. The 'super' coordinating structure of the REDD+ Task Force appears to have prevailed over the DNPI's leadership on REDD+.

\subsubsection{REDD+ pilot projects}

At least $44 \mathrm{REDD}+$ project initiatives are now underway in Indonesia (CIFOR and NCSU 2010), not all of which are official government-approved REDD-DA. Madeira et al. (2010) developed a preliminary typology for 17 REDD+ projects under development in Indonesia in mid-2009, dividing them into (1) those which aim at directly reducing emissions from deforestation and degradation in geographically distinct and contiguous areas; (2) those which are identified by their proponents as REDD+; and (3) those which are operating under official agreements with some level of government.

In December 2010, the President announced the selection of Central Kalimantan as a pilot province to carry out pilot testing of the initial stage of REDD+ in Indonesia as part of the LoI with the Norwegian government. A second province-wide pilot may be chosen by late 2011 as part of this agreement. The province will be used as a site for testing strategies 


\section{Box 3. The Letter of Intent between Indonesia and Norway}

In May 2010, a Letter of Intent (Lol) was signed between Indonesia and Norway to set up a bilateral arrangement to contribute to significant reductions in greenhouse gas (GHG) emissions from deforestation, forest degradation and peatland conversion (Gol and Government of Norway 2010). Norway has pledged US\$1 billion: \$200 million for the first 2 phases up to 2014, with the rest ( $\$ 800$ million) for 'performance-based' emission reductions. To date, $\$ 30$ million has been disbursed (Brown and Peskett 2011).

Activities under the Lol are divided into 3 phases. The first phase (scheduled to run from July to December 2010) was intended to include the completion of the national strategy, the establishment of an independent MRV institution, the design and establishment of a funding instrument and the selection of a province-wide pilot area. The second phase (2011-2013) will involve operationalising the funding instrument; developing Tier 2 MRV and improving it to Tier 3; imposing a moratorium on all new concessions from peat and natural forest; strengthening the enabling conditions for REDD+ (database, law enforcement and tenure conflict resolution); and implementing the first province-wide pilot programme and establishing a second. The third phase (from 2014 onwards) is intended to involve 'contribution of verified emission reductions' and the implementation of a GHG emission reduction verification mechanism.

Three working groups were formed consisting of representatives from government agencies, funding bodies, NGOs, private companies and Adat communities. The first working group is tasked with designing an institution to manage and monitor the fund distribution. A second group is formulating presidential regulations for (1) the organisation of an institution that will receive and monitor the distribution of funds and (2) the regulation of the moratorium on logging concessions in natural and peatland forest. The third working group is developing criteria and indicators for selecting a pilot province (MoF 2010b).

and approaches including 'processes for granting and managing forest concessions, improving transparency and reducing corruption in the bureaucracy, strengthening law enforcement, and ensuring that benefits generated from forest conservation reach local communities' (Butler 2011).

\subsubsection{Donor-driven financing and programmes}

A number of international initiatives have been adopted in Indonesia, such as bilateral cooperation agreements with other countries, including Norway, Australia and Germany. Norway in particular has had a significant role in increasing the pace of change and debate over REDD+ (see Box 3). Other significant multilateral donor-related developments include the establishment of a Climate Change Trust Fund with the UN Development Programme (UNDP) appointed as an interim trustee and the signing of the national UN-REDD+ programme. In 2009, Indonesia submitted its Readiness Planning Proposal to the Forest Carbon Partnership Facility (FCPF) and was subsequently selected as a Forest Investment Program (FIP) pilot country. The FCPF grant is intended to finance a subset of the overall financial and technical inputs required for Indonesia to reach REDD+ readiness.

\subsubsection{Moratorium on issuing new licences}

The Joint Concept Note for Phase 1 of the implementation of the Norway-Indonesia REDD+ LoI (GoI and Government of Norway 2010) stipulated a 2-year moratorium on all new concessions for conversion of peat and natural forest, with the aim of limiting conversion. However, its ability to achieve this aim is unclear because the Presidential Instruction issued in May 2011 to implement the moratorium applies only to peatland and primary forest. This leaves large areas of secondary forests open for exploitation. In addition, this moratorium does not affect existing plantation concessions, regardless of their location. 


\section{MRV for domestic legitimacy and international credibility}

\author{
A key requirement for REDD+ is the establishment \\ of an MRV system that has domestic acceptance \\ and international credibility. This involves attention \\ to clear standards, independent verification, \\ transparency and the inclusion of safeguards. \\ Similar requirements exist for the credibility and \\ acceptance of legality systems.
}

International legitimacy is a crucial aspect for both REDD+ and FLEGT-VPA as it ensures the sustainable flow of finance (whether fund or market based); domestic legitimacy is important to ensure that the process is nationally owned and has public oversight. Therefore, a key requirement for both REDD+ and FLEGT-VPA is the establishment of an MRV system that has domestic acceptance and international credibility and, therefore, a certain level of sophistication. Attention to credibility and legitimacy (both these principles feature in the IPCC Good Practice Guidelines) can be enhanced by attention to clear standards, traceability of the product (be it timber or carbon), thirdparty validation and verification, ${ }^{10}$ transparency and compliance with social and environmental safeguards. General principles seem to be that MRV should be transparent and participatory, should adhere to principles of free, prior and informed consent (FPIC) and should involve independent review, evaluation and nationally led independent monitoring (Saunders and Reeve 2010: 30). The IPCC Good Practice Guidelines, for example, state that greenhouse gas (GHG) inventories documenting LULUCF carbon emissions and removals need to be 'adequate, consistent, complete, and transparent' (IPCC 2003). In the case of Indonesia, the REDD+ Strategy indicates that MRV will be carried out according to all of these international standards. Regardless of whether the REDD+ Strategy is adopted in its current form, it is likely that the principles listed in the document (Box 4) will remain

10 Verification helps demonstrate whether particular standards have been met and intended results achieved. Validation deems that a process has been carried out in accordance with particular standards but does not include claims about results.

\section{Box 4. Principles listed in the REDD+ Strategy}

Formulate national standards in line with international protocol ${ }^{a}$ and good practices to measure changes in the carbon stock of the forests

- Establish an independent national institution to carry out the measuring and verification of information $^{b}$

- Develop a mechanism for coordinating and harmonising the calculation of carbon and an MRV system across sectors and scales

- Develop a non-carbon MRV system including social and environmental safeguards

- Develop a coordinated and transparent system by using the available technology to manage the information and ensure that all relevant information, both spatial and non-spatial, is available on a regular basis and can be accessed by all stakeholders

- Develop a mechanism of reporting to the relevant institutions at national and international levels

Source: REDD+ Strategy (Gol 2010: 46)

a The strategy does not specify which 'international protocol'.

b Note that in the more recent draft version of the REDD+ Strategy (not yet finalised), the text on the issue of verification has been changed to: 'The MRV institution should have an organised and verifiable REDD+ registry by independent institution, transparent and accessible by the public.'

key requirements of an MRV system for REDD+. Therefore, in the following sections, we discuss each of these requirements and what can be learnt from the experience with illegal logging measures in relation to these issues. Indeed, attempts to address illegal logging were made in a context in which most of these requirements were lacking or inadequate; they therefore came to constitute key concerns when designing such measures. For example, the process of designing the licensing system in Indonesia stalled partly because they needed to address criteria in international standards, as required by the VPA. 
The key elements of MRV for carbon emissions are (1) the establishment of reference emission levels (RELs) and (2) monitoring and reporting on actions that reduce forest carbon emissions and/or enhance forest carbon stocks, where these actions demonstrate additionality and real emission reductions against these RELs. Above all, to ensure that emissions have indeed been reduced, they must be monitored and reported against clear standards. Many issues arising in the design of MRV for REDD+ can draw on the experiences from measures to tackle illegal logging. These include:

- problems with data, including difficulties determining the scope of the standards;

- the need for independence in validation, verification and oversight mechanisms;

- issues of leakage, displacement and unintended impacts;

- challenges related to capacity; and

- the need to avoid duplication in system design.

Similar challenges arise when establishing any kind of MRV system, whether for timber products, emission reductions or social/environmental impacts.

\subsection{Clarifying the institutional framework: Data challenges}

A number of fundamental issues connected to data have proven challenging for initiatives addressing illegal logging and REDD+ alike; such challenges are rooted in the institutional complexities and lack of clarity. These include:

- the existence of contested definitions and data estimates as well as problems related to measurement capacity and quality of data; and

- the governance architecture in terms of the institutions for managing and sharing data, coordination and the data management systems amongst and within institutions.

\subsubsection{Contested definitions and data for setting standards and RELs}

Problems related to data inconsistencies, incomparability and contestation create difficulties for setting standards/RELs. This is particularly pertinent for REDD+, under which compensation is based on outcomes, in contrast to measures such as
VPAs, where performance is assessed on adherence to process.

Problems with data in both the illegal logging and REDD+ arenas include:

- the existence of unclear, multiple and contested definitions; and

- contested data estimates and information on key issues for setting RELs and standards.

The problem of multiple and contested estimates is a notable feature of the illegal logging arena. For example, there are huge disparities in the available estimates of illegal logging rates in Indonesia. These disparities have to do with the different time spans covered in the assessments, different sources and different types of data used, as well as differences in calculations (see Box 5). Such disparities prevent discussions about the extent of illegal logging in terms of absolute numbers and make ranges and projections controversial. Lack of clarity over the extent of the problem has also hampered the design of appropriate measures to tackle illegal logging. Whilst general indicators can give an indication of the direction and trends in illegal logging, they become a problem when absolute numbers are needed - as in the case of REDD + - because verification of performance and carbon payments depends on specific figures. If illegal logging cannot be estimated more accurately, national REDD+ accounts are likely to be skewed.

Data inconsistencies, incomparability and contestation present a particular problem for setting and monitoring standards/RELs for REDD+. There are many parallels between this situation and the various estimates of the supply-demand gap, as discussed above. Monitoring of forest cover changes in the developing world has been problematic for decades (Matthews 2001, Grainger 2008). In Indonesia, problems exist in data collection, processing, statistical analysis and reporting. Accurate classification of land cover, needed for precise establishment of RELs and monitoring of carbon, remains a key challenge for REDD+. This will require accurate maps of the different types of forest, their location and where the operations are taking place, as well as spatial data on rights and permits (Dermawan et al. 2011). However, even estimates of the area of forest vary as different agencies use different maps 


\section{Box 5. Contested data: Illegal logging estimates}

Accurate estimates of illegal logging are important for defining its contribution to deforestation, which in turn is important for establishing the reference levels needed to establish deforestation rates and RELs. Inaccurate estimates of illegal logging will result in inaccurate RELs. However, a CIFOR review of these estimates of the supply and demand gap (as a measure of illegal logging) in Indonesia reveals a number of shortcomings, which make it difficult to draw accurate conclusions about its scale over time.

The gap between supply and demand is one variable that can be used to estimate illegal logging rates. The problem of data variability is shown in the large variation in results between studies estimating the supply and demand of timber, as there is not yet any commonly agreed and replicable approach to measuring and monitoring it. A comparison of 5 studies (Scotland et al. 1999, Brown et al. 2005, Manurung et al. 2007, Tacconi 2007, Human Rights Watch 2009) that estimate supply and demand dynamics in Indonesia's forestry sector reveals that differences in the scope of analysis in each of the studies have significant impacts on the conclusion. The studies by Scotland et al. (1999) and Tacconi (2007) take into account domestic and international markets to estimate the supply and demand dynamics. These studies include export and import of timber to calculate the overall supply and demand, but they use different estimation methods. Scotland et al. (1999) included roundwood and processed timber imports in the supply-demand equation, whereas Tacconi (2007) included only roundwood imports. By contrast, the studies by Brown et al. (2005), Manurung et al. (2007) and Human Rights Watch (2009) cover domestic markets only. None of the studies considered all the markets and all the wood products. Furthermore, the data sources used are not easily compared. Different organisations use different methods of data collection and processing, which result in unverifiable figures over the long term.

developed using different methods. For example, the MoF shows the total forest area in the country as 99 million ha, whereas the Ministry of Environment (MoE) states that the area is 77 million ha (Kompas 2010a). Clarity is also lacking in relation to basic definitions, criteria and indicators associated with degraded land and its location. The draft REDD+ Strategy establishes a technical carbon threshold for land suitable for low-carbon development and land for conservation for carbon (GoI 2010: 28); however, the strategy does not indicate where this land might be or how much degraded land is available. This is a crucial point in the discussions surrounding REDD+ because of the government of Indonesia's commitment to allow legal deforestation for development purposes in degraded areas only and to prohibit deforestation activities in primary forests and peatlands.

MRV of carbon emissions for REDD+ requires both activity data and emission factor data (Box 6). Setting RELs depends on the availability of data on these variables. Indonesia's current national network of Permanent Sample Plots under the MoF does not adhere to the CDM (Clean Development Mechanism) Executive Board guidelines for sampling and sample sizes to estimate carbon pools. Also lacking is alignment amongst the many different forest inventories mandated by the government of Indonesia. ${ }^{11}$ Estimating activity data requires information on current and past levels of deforestation - an area that is itself contested. Data inconsistencies and incomparability are rife, and there have been long-term, and ongoing, difficulties in estimating changes in forest cover and condition given the huge range of deforestation statistics. For example, the Second National Communication to the UNFCCC (MoE 2010a) refers to much lower deforestation levels than those reported by others (see, for example, PEACE 2007 and MoE 2010a). Van Assen (2010) discusses how Indonesia's deforestation rate during the period 1985-2000 is estimated to have been between 0.8 million and 2.4 million ha annually (Sunderlin and Resosudarmo 1996, FAO 2007). One high estimate puts the number at more than 3.8 million ha per year or higher (Kleden et al. 2009), but other analyses suggest recent deforestation is much lower (FWI 2009).

11 These include the National Forest Inventory, Inventarisasi Hutan Menyuluruh Berkala (Periodic Comprehensive Forest Inventory), Inventarisasi Tegakan Sebelum Penebangan (Stand Inventory Before Cutting) and Plot Ukur Permanen (Permanent Sample Plot). 


\section{Box 6. Data needed for MRV of carbon emissions for REDD+}

Two types of data are needed for MRV of carbon emissions for REDD+: activity data and emission factor data.

- Activity data document land use, land use change and forestry (LULUCF) in a spatially explicit manner. This is generally done using remotely sensed data to monitor land cover changes using coarse- or medium-resolution satellite imagery and, in limited cases, with high-resolution satellite imagery, aerial photography and/or groundtruthing. Activity data explain where land cover change is occurring and to what extent. More detailed activity data (land use change matrix) than those used by MoF are needed for MRV of carbon. For example, there is a particular need to develop a hierarchical land use/land cover classification scheme that fits within the IPCC Good Practice Guidelines, using a system that is relevant to Indonesia and flexible enough to be able to account for the vast differences in ecosystems across the Indonesian archipelago.

- Emission factors are estimates of the change in carbon stocks associated with land cover change. Fine-scale emission factor estimates are derived solely from local data sources, whereas coarse-scale estimates may be global in nature. These coarse estimates (termed Tier 1 by the IPCC) are often used in the absence of locally derived information, which can be expensive to obtain and analyse (Gibbs et al. 2007). More data on the relevant emission factors are needed, as are models for estimating biomass for each of the 5 IPCC carbon pools (aboveground biomass, belowground biomass, litter, dead wood, soil), which can be based on environmental factors, in order to contribute to emission factors. Such data are also highly relevant for monitoring legality, because they allow for more accurate estimates of illegal logging and the areas where it may be occurring and support adequate response measures.

Uncertainty analyses are required for both activity data and emission factors, along with clear definitions and implementation of quality assurance/quality control protocols.

\subsubsection{Data sharing and coordination amongst institutions}

The institutional architecture emerging in the REDD+ debate is increasingly complex. Clarity regarding who has authority over MRV for REDD+ remains a key victim of this complexity. The fundamental question of institutional authority, and which institutions will have overall responsibility for decision-making on MRV, remains unresolved.

The Indonesian-Norwegian LoI includes an agreement to establish an 'independent REDD+ Agency, MRV system and financing instrument'. As outlined above, fundamental to the issue of data production and decision-making over standardsetting is the question of institutional authority and which institutions will have overall responsibility for decision-making on MRV and other aspects of operationalising REDD+. As discussed above, the challenge, for both illegal logging and REDD+, lies in the multiple contested estimates of such crucial factors as the volume of illegal timber produced and the amount by which carbon emissions might be reduced. Addressing this challenges requires some consensus on how these differences can be reconciled, whose knowledge 'counts' and who has the authority to make the decision over what constitutes the 'right' data. The need for this consensus is far more acute for REDD+, under which, in theory, compensation will be based on outcomes, in contrast to measures such as FLEGT-VPA, which bases judgements on adherence to process. The involvement of new actors in both the analysis and the use of the analysis threatens to exacerbate the situation for REDD+.

The measures for tackling illegal logging have, for the most part, been coordinated by, or around, the MoF. However, the institutional REDD+ landscape in Indonesia is marked by a number of other actors and their related strategies. The nature of the issues that REDD+ has to tackle means that it requires a much wider institutional scope for its MRV than do measures to address illegal logging; hence, it makes sense to avoid allowing any single department or government entity to dominate the MRV process. The creation of the interim task force 2010-2011 (triggered by the LoI) has reduced the 'monopoly' power of the MoF (Tacconi 2010). The institutional architecture currently emerging in the REDD+ debate is increasingly complex, with institutional territorial battles a recurring feature (see Dermawan et al. 2011 for more discussion). Clarity regarding 
authority over MRV for REDD+ is a key victim of this complexity.

The President has also assigned the UKP4 to set up an MRV institutional framework in response to the LoI, which includes plans for a new agency to create a national system to monitor, report and verify emissions and emission reductions based on international standards. The main challenge here is the commitment to independent verification methods. ${ }^{12}$ One model for the new agency that UKP4 (2010) proposed is for an independent national MRV institution that would operate under international and cross-sectoral national steering committees; this approach could avoid sectoral conflicts of interest. The institution would be responsible for monitoring and reporting reductions in emissions based on the international protocol and for developing an independent verification method. Both the international and the national steering committees would monitor the institution's implementation of MRV and accept input from an advisory committee. In 2010, other institutional options were discussed (see DNPI 2010, Kahar 2010, MoE 2010b), and the debate included whether the agency should be (1) a unit within the ministry (similar to the Treasury in the Ministry of Finance); (2) an agency reporting to the minister (similar to the National Space Agency [Lembaga Penerbangan dan Antariksa Nasional; LAPAN]); (3) an agency reporting to the President (similar to UKP4 or DNPI); or (4) an agency reporting to the public (similar to the KPK). Whichever institutional design is adopted, however, it remains unclear how such a REDD+ MRV agency would be related to sectoral road maps and strategies.

The most recent version of the REDD + Strategy proposes that the MRV agency should have a registry. The 'registry' function is critical for ensuring national coordination amongst REDD+ initiatives and

12 Indicators for the 'contributions for verified emissions phase' of the LoI note a commitment to independent verification: 'Indonesia receives annual contributions for independently verified national emission reductions relative to a UNFCCC reference level, or a reference level set by Indonesia and its partners based on Indonesia's emission reductions pledges and UNFCCC methodological guidance (4/CP 15), in accordance with relevant decisions of the Conference of the Parties, if no UNFCCC reference level has been set for Indonesia' (GoI and Government of Norway 2010). avoiding double selling. It is therefore an important part of building credibility. The REDD+ Strategy mentions the need for an MRV unit, which will be responsible for collecting relevant data to be placed in a central database, to be used for national estimations and international reporting, according to the IPCC Good Practice Guidelines. However, for the time being, data management activities that could support the MRV process in REDD+ are being carried out without any coordination amongst institutions. These include the MoF/Forest Research and Development Agency (FORDA), LAPAN, the MoF/Forest Planning Agency (Baplan) and the MoE. There are also a number of relevant regulations and related initiatives, some examples of which are laid out in Box 7.

\subsubsection{Determining the scope of standards}

The breadth of the legality standards has proven a major sticking point in debates. For example, early concerns were raised that the standarddevelopment process did not pay sufficient attention to gazettement, and has shifted away from FPIC to consultation with local communities. These concerns remain in some quarters. Challenges related to the legality standard-setting process are likely to be even greater in debates on forest definitions, which will define eligibility and other standards for REDD+ and are all much wider ranging than the legality debate.

A REDD+ mechanism will require clarity regarding land and forest ownership and user rights. The REDD+ Task Force has already encountered a challenge in terms of clarifying inconsistencies between local and national laws and the ways in which these inconsistencies create confusion and conflicts in relation to spatial planning, forest definition, forest area, licensing processes and demarcation of legal rights. The FLEGT-VPA process faced a similar problem with the need to prioritise amongst more than 900 forest-related laws. Although it is unlikely that the SVLK framework could be used as a blueprint, the related multistakeholder process may well offer lessons for the REDD+ Task Force in this respect. This experience illustrates how intensive use of consultation processes led to consensus on which aspects should be included in the legality standards. The long process of developing the legality definition as part of the 


\section{Box 7. Recent data collation initiatives}

A 2011 law in Indonesia (UU No. 4/2011) established the mandate for standardisation of map products under BIG (Badan Informasi Geospasial, formerly Bakosurtanal; Geospatial Information Agency) as the clearing house for spatial information on (1) basic map data and (2) thematic map data. The law grants BIG clear authority to develop, produce and publish basic map data including (but not limited to) political and administrative boundaries, coastlines, contours, hydrology and roads. Thematic map data such as land cover (including forest) and land cover change can be submitted to BIG for inclusion in the official clearing house as long as the data follow basic standards and procedures (which are currently in development). It is not clear whether BIG will be able to standardise land use/land cover classifications across all the ministries so that one classification system will be used, or if BIG will only standardise the process of developing classifications. In the case of the latter, the existing problem that different ministries' land cover maps are not aligned could remain an issue. Theoretically, however, it seems that BIG would have the authority to choose one map source or classification as the official source (i.e. LAPAN), or it could possibly align classifications in-house, resulting in one map constructed from many input sources.

The MoF's Forest Planning Agency (Baplan) is currently creating a Forest Resource Management System (FOMAS) which includes the Forest Resource Information System (FRIS) and the Indonesia National Carbon Accounting System (INCAS). The FRIS aims to generate data to support the establishment of RELs and wider sustainable forest management (SFM). It will involve a remote sensing programme, geo-database and data-sharing component (Forest Planning Agency undated in Scheyvens 2010: 41) and it will provide input into the INCAS. FOMAS will also collate data on logging operations.

The INCAS is also currently under development by Baplan with technical assistance and funding from Australia. The aim of the system is to provide a comprehensive and credible account of Indonesia's land-based emissions profile and sinks capacity. It could eventually enable Indonesia to develop robust modelling and projection capacity for land-based carbon accounting, and therefore robust emissions and removals estimates (Forest Planning Agency 2008 in Joshi et al. 2010). The INCAS has plans to coordinate all sectors through INCAS management committees, which will consist of representatives from key agencies; furthermore, the Second National Communication nominated the INCAS as one possible scheme for sharing data amongst sectors (MoE 2010a). The original REDD+ Strategy stated that the government of Indonesia should 'support' the INCAS, although the more recent draft version (not yet finalised) of the REDD+ Strategy (March 2011) notes that the MRV institution will be required 'to work with' the INCAS.

The MoE is developing a national GHG inventory system for reporting to the UNFCCC. Theoretically, this system will take GHG source/sink estimates from all sectoral sources (forestry, agriculture, transportation, industry, mining, etc.). With estimates from all sources, it will then develop reports for the National Communications. It is currently unclear how this will be connected to other systems.

All sectors have an internal system for monitoring and evaluation (Monev), which is reviewed by the inspectorate general and the Supreme Audit Board (Badan Pemeriksa Keuangan; BPK). One option is to streamline a REDD+ MRV system into this system by adding new indicators of GHG emissions to the Monev (Mott Macdonald 2010).

FLEGT process in Indonesia also made it possible to identify the different roles and responsibilities of the governments, agencies and operators involved. During this process, it was recognised that conflicts could not be prevented unless ownership and use rights over land, forests and carbon were clarified first. FLEGT has made a first step in this regard by listing the applicable provisions that apply to the rights of indigenous and local communities in the case of Indonesia as part of the work on the legality definition.
Challenges related to the SVLK standard-setting process are likely to be even greater in debates on forest definition and other standards for REDD+, which are much wider ranging than the legality debate. The debate over the breadth of the standards (which has been ongoing since 2003) has been a major sticking point for the FLEGT-VPA-related process. On the one hand, the EU has made it clear that timber legality standards will not be imposed on producer countries because defining legality is each nation's sovereign right. On the other hand, 
the 'market' (and the multi-stakeholder process used to develop the standard) demands that a legality definition cover more than the technical aspects of CoC. The need for acceptance by the international market is evident in the experience of the LEI, which was not able to maintain the international credibility of its Indonesian standard once it became separated from the international FSC process (see Section 2.5). The agreed standards for the definition of legality are framed around a number of key principles covering (1) the legal status and area, and right to use the forest; (2) compliance with the legal requirements for harvesting; (3) compliance with the environmental and social aspects related to harvesting; and (4) supply chain management of timber from the forest through processing units to the point of export (GoI and EU 2011a: 4).

One of the main concerns was that the lack of clarity regarding authority between different levels and sectors of government would make it possible for a batch of timber to be judged both legal and illegal, depending on which interpretation of the governing authority is prioritised (Cashore and Stone 2010). Another source of unease is that the standards do not adequately consider the issues of FPIC and legal gazettement of concession boundaries where the tenurial status of the national forest estate is under dispute (Walhi 2006). The concern is that only $11 \%$ of the national forest estate has been gazetted in line with stipulated procedures ${ }^{13}$ (Brown et al. 2008: 175). The process of gazettement in Indonesia involves the demarcation and delineation of boundaries and adherence to due consultation processes, which would help increase security of title. This low percentage means that only a relatively small proportion of forestland has clearly defined boundaries. A report by the BPK suggests that less than $5 \%$ of forest in the provinces of Riau, Jambi, Central and East Kalimantan and Papua have clear legal title, with less than $1 \%$ in Central Kalimantan (Jakarta Post 2010b). Furthermore, without complete

13 At the same time, the 1999 Forest Law treats areas under the control of traditional law communities (butan adat) as one category of the national forest estate rather than as private forest. In addition, there is currently no mechanism for registering collective claims, despite recognition of traditional law systems in the Basic Agrarian Law (1960) (Contreras-Hermosilla and Fay 2005). Consequently, significant areas of the national forest estate are the subject of local disputes. mapping data, the exact extent of claims to forestland remains unclear.

At the same time, industry expressed concerns that a complex legality standard would lead to increased production costs and the loss of competitive advantage internationally to countries that may have weaker standards (particularly on tenure and indigenous rights; Wells et al. 2007: 11). Consensus was eventually reached as some stakeholders accepted that compromises had to be made. Currently, 'requirement for gazettement' is included in the sustainability (PHPL) standards of the SVLK but not as a 'key' indicator; in theory, therefore, it is possible to get legality certification without the completion of gazettement. If an operator can prove that the gazettement did not occur due to neglect by the government (for example, that it paid as required but the government did carry out its due responsibility), then it can get a legality certificate. FPIC currently appears in the legality standards only as part of the requirement for an EIA (Analisis mengenai Dampak Lingkungan; AMDAL).

As REDD+ is intended to be a financing mechanism based on performance, measuring changes in carbon emissions is fundamental. The wider scope of what will be included in a REDD+ agreement under the UNFCCC in terms of MRV has not yet been determined, and the discussion over the inclusion of safeguards, and whether the agreement will include MRV of sustainable development policies and measures, has not yet been resolved. Chapter III of Cancún Decision 1/CP.16 refers to 2 appendices that set out guidance and safeguards and that include broad principles. Amongst these are the principles that REDD+ activities be consistent with parties' national sustainable development needs and goals, that safeguards be supported, and that the knowledge and rights of indigenous peoples and members of local communities be respected (FIELD 2011). The debate has concentrated on the extent of UNFCCC involvement in specifying the nature of social and economic safeguards. Changes made to the final Cancun text have created uncertainty about what body would be established to report on safeguards, it has been suggested that these changes represent a watering down of the final text with regard to safeguards. Since the COP in Cancún, Indonesia (with the MoF taking the lead) has begun the process 
of defining its own social and economic standards for safeguards. Regardless of the final UNFCCC decision, there is a strong argument that MRV for credibility requires not only emission reductions but also attention to 'non-carbon' issues (Saunders and Reeve 2010).

Indeed, according to the REDD+ Strategy, the scope of an MRV system must not be limited to measuring changes in the area of forestland based on type and carbon stock in the forest; rather, it must also consider achieving (or monitoring) good management and sustainable development. MRV will therefore require monitoring standards not only for direct carbon emission activities but also for other co-benefits, associated financial flows and the distribution of benefits. In the meantime, the rules for MRV systems are evolving under bilateral agreements and Indonesia has begun developing its own definitions of key variables to be monitored. In addition, the National Forestry Council has used a formal consultation process to develop policy recommendations (DKN and UN-REDD, no date), which could act as specific guidelines for an FPIC process.

One of the most pressing tasks for REDD+ projects is to demonstrate clear title and clarify competing claims of communities. For example, MoF Regulation No. 30 (P.30/Menhut-II/2009) for REDD+ applications stipulates certain information that the project proponent must provide; such information includes proof of absence of conflicts and competing claims and involvement of stakeholders in forest management.

In terms of synergies, much of the information needed for the SVLK process is of direct use for REDD+. This information includes inventories, management plans and harvest data. Licensing of REDD+ projects will depend on compliance with legality requirements. Therefore, the opportunity for the REDD project approval process to refer to the SVLK is clear, at least as one step in the approval process in relation to compliance with legality standards.

There are also many other standards that REDD+ MRV could draw on (Merger et al. 2011). These include various sustainable forest management certification standards and REDD+ project and programme standards such as the Voluntary Carbon Standard (VCS) and the Climate, Community and Biodiversity Alliance (CCBA) standards. The REDD+ Social and Environmental Standards (developed by a group led by CCBA and CARE) are currently being tested in Central Kalimantan. The validation process for REDD+ projects following the CCBA project standards involves stringent requirements for documenting the process and the effectiveness of community consultation throughout the project preparation period. A key future challenge for REDD+ will be the negotiation of credibility between the use of national as opposed to international standards, particularly given the recent proliferation of international voluntary standards that address carbon accounting and/or social and environmental safeguards to varying degrees (Merger et al. 2011).

\subsection{The ' $V$ ' in MRV}

No decisions have been made regarding verification of emission reductions under REDD+. However, it is clear that there will be requirements for independence of verifiers, a single licensing authority, strong internal controls to ensure payments are actually made and additional emission reductions, amongst others. The SVLK is a timber legality assurance system based on a certificationtype approach of 'operator-based licensing'. Controversial points include the system's low levels of internal control, the fact that Indonesia has more than one licensing authority and the requirement for impartial auditors. In these respects, the SVLK experience can inform REDD+.

In this section, we examine the SVLK and the lessons that can be extrapolated for REDD+ verification. The SVLK is the timber legality verification system for the VPA. It was made law in June 2009 but had been in development since 2003 (see Box 2). The SVLK is an integrated system that can track the movement of timber from the forest to mills and then to domestic and international markets, and involves independent auditing by ISO-accredited auditors against a legality standard. About 15 forest concessions and 55 factories have so far been audited. 
In terms of adhering to international standards and achieving international credibility, a number of pre-existing problems with the control and verification of the legality of timber were present (Box 8). Many of these have been resolved through modification of the SVLK, although some remain. A gap analysis coordinated jointly by the Indonesian government and the EU was carried out to assess the compatibility of Indonesia's system with the Timber Legality Assurance System (TLAS) required by the EU. The analysis found that 2 additional elements were required for the VPA to proceed. These were (1) a licensing scheme that had more specific descriptions and guidelines to ensure monitoring of the $\mathrm{CoC}$ of timber flows from the forest to timber markets, and (2) stronger provisions on third-party independent verification (EU-Indonesia FLEGT VPA Experts 2010).

The Indonesian legality verification system is based on a certification-type approach of 'operator-based licensing' in which the MoF nominates a number of Conformity Assessment Bodies (CABs) to audit the legality of operations of timber producers, traders, processors and exporters (see Figure 2 from GoI and EU 2011c). Two types of certificate can be issued under the SVLK: PHPL (for SFM) and VLK (for timber legality). An operator that has a PHPL does not need a VLK. There are 2 types of CAB:

- assessment bodies, which audit the performance of the forest management unit (FMU) against the sustainability standards; and

- verification bodies, which audit the FMUs and forest-based industries against legality standards (GoI and EU 2011c: 16).

The CABs are accredited by the independent accreditation body, Komisi Akreditasi Nasional (KAN). KAN signed an MoU with the MoF in July 2009 to provide accreditation services. The CABs also act as the export licensing authority to issue export licences (V-Legal or FLEGT licences) for individual shipments. Auditors within the CABs are accredited to license either the SVLK or export licences or both. The audit process involves assessing compliance with the sustainability and legality standards. Key amongst those organisations are the Timber Industry Revitalization Body (Badan Revitalisasi Industri Kayu, BRIK) and the LEI, which is an accreditation/ standard-setting organisation for green commodities, mainly timber).

Part of the audit process requires public consultation with 'community, related agencies and partners on the planned performance assessment of the Licence Holder concerned' (Regulation P.02/VIBPPHH/2010:II.C.2). The audit team prepares a report to the $\mathrm{CAB}$, which it submits to the auditees and the MoF; the $\mathrm{CAB}$ then uses the report to decide on the outcome of the verification audit. The $\mathrm{CAB}$ must then report the audit results and decisions to the MoF. If the operator is found to be compliant, the company gets a legality certificate for 3 years. Any infringements detected will be reported to the $\mathrm{MoF}$ and handled in accordance with administrative or judicial procedures. Concerns raised about the design of this element of Indonesia's TLAS, or SVLK (see, for example, Telapak et al. 2009), include the following.

- The low levels of internal control in the system whereby the $\mathrm{CAB}$ that carries out the evaluation/ verification also issues the certificate and handles the objection: 'We proposed supervision bodies, management bodies and monitoring bodies ${ }^{14}$. But the government was trying to think of a cheaper system and discussed the accreditation body existing now' (MFP 2010 quoted in van Heeswijk 2010: 108). In other countries, verification functions have been separated from VPA licensing (EU-Indonesia FLEGT VPA Experts 2010). In Indonesia, however, the notion of a separate licensing body has been tainted by the experience with the controversy over BRIK (see Box 8).

- Indonesia also differs from other VPA countries in that it has more than one licensing authority. This has been justified by the size of the country, the nature of its decentralised government and the argument that KAN enables consistency (EU-Indonesia FLEGT VPA Experts 2010). The requirement for impartial but qualified verifiers may be unrealistic, as the organisations accredited to carry out SVLK verifications have few qualified staff members. Currently, there are

14 The newly revised SVLK regulation (Regulation No 38) is expected to have dealt with this problem but the this regulation is not yet in effect. 


\section{Box 8. Credibility problems with previous timber control and verification systems in Indonesia}

- The timber administration system had limited resources for oversight. Emphasis on self-regulation had increased and provinces and districts had little incentive to engage.

- Independence and transparency in the forestry sector monitoring and audits were lacking. Under the Independent Assessment Body (Lembaga Penilai Independen; LPI) system, independent assessments of forest managers' compliance levels were carried out. As the MoF could accredit auditors, evaluate reports and issue verification decisions, the LPI system was said to be vulnerable to political interference. In addition, these evaluations tended to proceed on a case-by-case basis - a system that did not necessary identify the larger-scale infringements (Brown and Stolle 2009: 12). Findings and follow-ups by the MoF to the results of the inspections by the National Monitoring and Evaluation Team (Tim Evaluasi dan Pemeriksaan) tended to be secret.

- Clarity was lacking regarding the sanction measures used against operators found by LPI audits to be in violation (Brown and Stolle 2009: 12).

- Credibility was lacking regarding export licences. Until recently, export licences were issued by the Timber Industry Revitalization Agency (Badan Revitalisasi Industri Kehutanan; BRIK). However, credibility of these licences was low because of the lack of physical inspections in the audit process, as BRIK only matched quotas with transport permits. In addition, there were potential conflicts of interest as BRIK was a membership organisation for timber exporters at the same time as having the mandate for issuing export endorsements. It was also accused of having acted to consolidate an export cartel of its own members and imposing illegal charges. This type of problem can develop when a single body has monopoly over issuing export licences (Wells et al. 2007: 24).

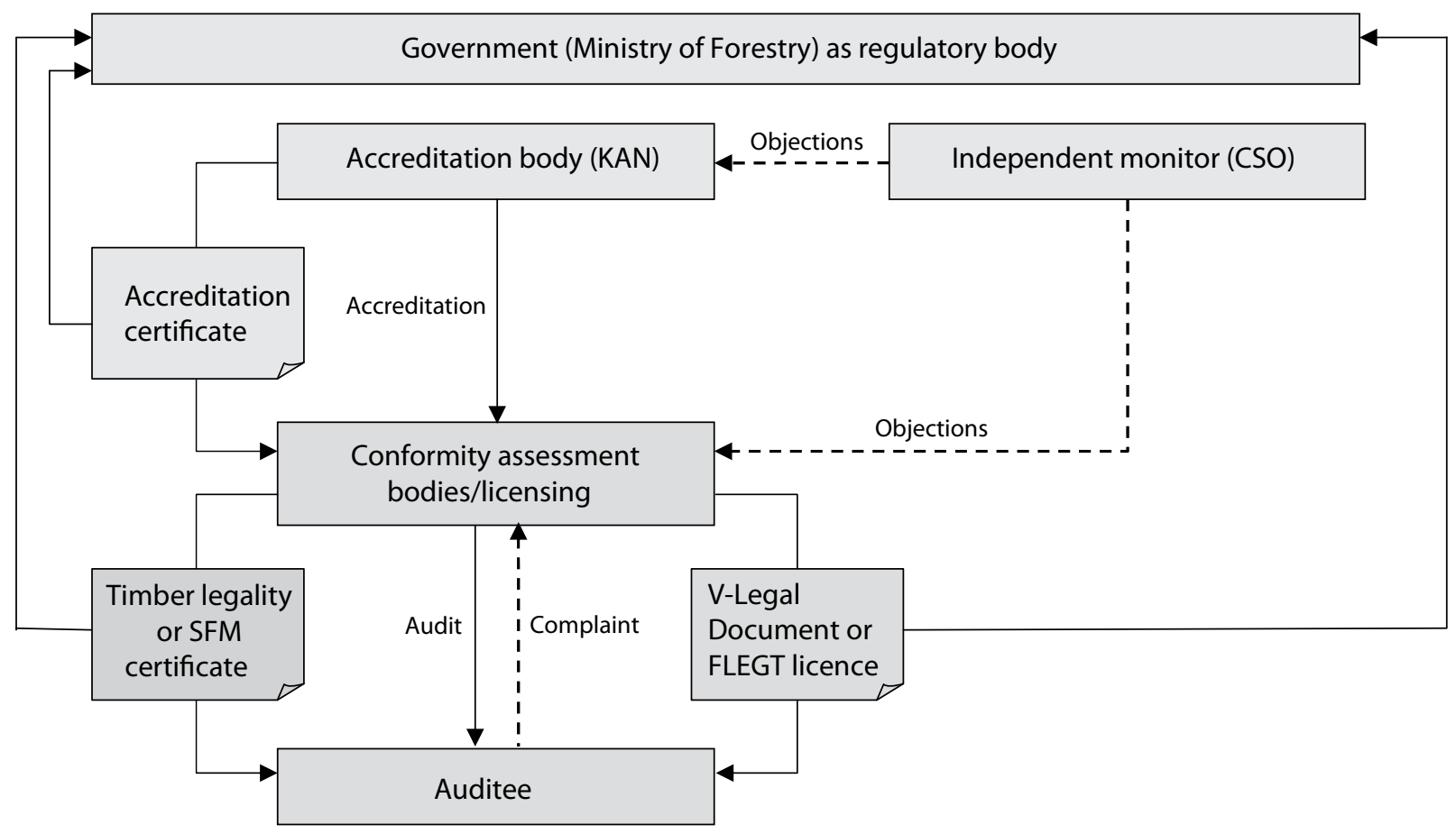

Figure 2. Institutional set-up of Indonesia's TLAS, or SVLK (from Gol and EU 2011c) 
150 trained people trained to do SVLK audits. Most of the experienced staff who are currently certified to undertake SVLK verification have a history of close ties with the industry, placing into question their impartiality.

- BRIK is currently playing a dual role: as an SVLK verifier and as the government agency that continues to issue endorsement certificates for the export of timber without the SVLK. It is expected that once the number of qualified agencies and staff for SVLK verification increases, the role of BRIK in SVLK verification will diminish and that BRIK will eventually be dissolved.

\subsubsection{Designing for independence}

The principle of separation of mandates for accreditation, standard-setting, monitoring and verification is fundamental for the independence - and thus the credibility - of both the SVLK and the REDD+ system. Clear reporting, public consultation and public disclosure provisions and mechanisms for corrective action can serve to strengthen both mechanisms.

One of the greatest challenges in the climatechange-related negotiations on REDD+ has been the debate over the verification of mitigation actions by developing countries and whether it should be carried out domestically or internationally and with or without international support (Saunders and Reeve 2010: 25). During negotiations, the G77 raised concerns that although international, external financing for MRV was acceptable, a requirement for international approval of a national MRV system would violate national sovereignty. However, irrespective of how REDD+ MRV systems and standards evolve, it is likely that independent verification will be a requirement for trading forest carbon credits in any market, whether a compliance or voluntary one. ${ }^{15}$ This is reflected in Indonesia's

15 This will definitely require some changes to the existing verification systems. As one example, the 2010 P3 regulation published by Forestry Business Unit (Bina Usaha Kehutanan; $\mathrm{BUK}$ ) of the MoF provides guidelines for carbon measuring, monitoring, reporting and verification. The regulation sets out data collection procedures for establishing an REL for forest carbon emissions in concessions, and states to whom the reports must be submitted and who is responsible for verifying the information in the reports (district-level forestry staff). However, the regulation does not establish the reasons for doing
REDD+ Strategy, which indicates that a necessary part of the REDD+ system is a facility for an independent agency to audit adherence to standards.

Many of the concerns clouding the design of the SVLK and the Indonesian VPA have revolved around the issue of how to guarantee independence. Thus, the experience of the FLEGT-VPA provides a number of lessons on how to create independence in a system for REDD+ monitoring and verification. A key principle in this respect is the separation of mandates, that is, ensuring the mandates for accreditation, standard-setting, monitoring and verification are held by different entities. Before the SVLK was introduced, concessions were required to qualify for certification by the Independent Assessment Body (Lembaga Penilai Independen; LPI), to meet the MoF-devised evaluation criteria. There was no outside validation of the process or verification of the results, and the process had a poor reputation.

Under the VPA, Indonesia has 4 forms of independent monitoring for legality verification (Box 9); 2 of these are incorporated into the SVLK and 2 are additional for the purposes of the VPA. The facility for independent observation and oversight is a crucial aspect of the SVLK's credibility (EU-Indonesia FLEGT VPA Experts 2010) and a requirement under the VPA. For the purposes of the VPA, 'independence' is defined as being independent from other elements of the SVLK, that is, those involved in the management or regulation of forest resources must be separate from those involved in the independent audit.

Although comprehensive details of how these various evaluations will take place are still under development, features that might enhance their credibility and that may be relevant to the design of REDD+ and MRV systems include:

- clear and public reporting and public disclosure provisions that apply to the CABs;

the monitoring (i.e. whether the goal is avoided deforestation, improved forest management via reduced degradation, etc.), nor does it establish a system for feeding reporting into a national system that counts towards the REL or provide for transparent validation/verification procedures. 


\section{Box 9. Forms of independent monitoring for legality verification under the VPA}

- Independent monitoring by civil society to assess permit holders' and CABs' compliance with standards.

- A 'comprehensive evaluation' by a multi-stakeholder monitoring working group to oversee the functioning of the Indonesia's SVLK.

- Periodic (annual) evaluation undertaken by an independent auditor recruited by the Joint Implementation Committee (JIC) to provide independent assurance that the SVLK is functioning as described; this will enhance credibility of the licences. As a requirement under the VPA, this function corresponds to that of the 'thirdparty monitor' in the FLEGT documentation (FLEGT 2007) and will be used to monitor and review the SVLK, identify gaps and monitor the progress of implementation of the agreement. It will cover functioning of control measures from forest to export, data management, timber traceability systems and issuance of FLEGT licences, as well as the production, licensing and trade statistics relevant to the VPA (Gol and EU 2011d).

- Independent market monitoring to assess how policy affects the position of timber on the market.

There will also be an independent technical evaluation, which will take place before FLEGT licensing starts, to examine any revisions made to the TLAS, or SVLK, after the VPA was signed (Gol and EU 2011e). This independent technical evaluation will assess whether there are adequate mechanisms for dealing with non-compliance identified during the verification process or brought forward through complaints and independent monitoring.

Note: In terms of complaints being raised about the periodic evaluation, the bilateral $\mathrm{JIC}$ is charged with negotiating controversial issues.

- facility for public consultation; ${ }^{16}$

- a mechanism for corrective decisions on verification results and action where breaches are identified;

- $\quad$ adequate and publicly available records on the breaches of policy and practice identified, corrective decisions on verification results and actions taken to address non-compliance;

- mechanisms to report to the government on verification findings of CABs; and

- redress mechanisms and methods for dealing with non-compliance and attempts to undermine the process.

One of the key dilemmas in designing a verification system is how to avoid a situation where the source and nature of financing for verification compromise its independence (Saunders and Reeves 2010: 42) As it is currently unclear whether a premium will be recoverable on the exported product (GoI and EU 2011a: 8), financing of the SVLK verification system remains an unresolved issue. For the time being, the

16 Lessons from the voluntary carbon market also emphasise the importance of this; unlike the CCBA, the earlier version of the VCS Guidelines on methodology development, for instance, did not include a 30-day public consultation process, although this has since been revised. auditees will be responsible for financing an objection (Regulation P.02/VI-BPPHH/2010: 8). This is a key weakness (also faced by FSC) as it may compromise independence. Some funding is available from the MoF; however, in the past, MoF funding of the LPI also raised questions about independence. Reliance on donor funding is one way to ensure independence from political or industry interests. However, there are arguments in favour of funding from national sources, particularly with respect to REDD+, for which sovereignty is an issue. One potential model is the ombudsman model, in which financing is allocated by Parliament (Brown and Tucker 2006: 7). If the monitoring framework is placed within the national framework, financing can easily be channelled through the national budget (although not necessarily the MoF budget). This could be problematic if monitoring has an international function, but it may help retain an important element of accountability to national institutions (Saunders and Reeve 2010: 42).

\subsubsection{Civil society 'independent monitoring'}

Civil society 'independent monitoring' under the SVLK differs from 'independent monitoring' as required by the EU. The latter is performed by periodic evaluation. Relevant lessons for REDD+ relate to ways to increase the effectiveness of civil 
society monitoring, including requirements for clarity of process, public access to information and guidelines for impartiality.

Indonesia has formally recognised a civil society 'independent monitoring' function in the SVLK that allows civil society to submit objections (Box 10) when irregularities are found in the accreditation, assessment or licensing processes ( $\mathrm{GoI}$ and $\mathrm{EU}$ 2011e: 9). 'Third-party monitoring' as required by the EU for a VPA is different from the civil society 'independent monitoring'; in the case of Indonesia, this 'independent monitoring' will be the function of the country's civil society networks, which, arguably, serve more in a domestic oversight role. This type of monitoring allows civil society to submit complaints, but it does not fulfil the criteria for 'third-party monitoring' as required by the EU. 'Third-party monitoring' takes place through 'periodic evaluation'. An alternative would have been to use a body with ISO standards contracted through transparent procedures to periodically monitor SVLK implementation (EU-Indonesia FLEGT VPA Experts 2010).

A civil society independent monitoring network, called JPIK (Jaringan Pemantau Independen Kehutanan), has been set up to carry out civil society 'independent monitoring'. Established in
September 2010, JPIK consists of at least 40 NGOs and 120 individuals from around 16 provinces in Indonesia; many provinces have their own focal point. Currently, the aim of JPIK is to monitor the implementation of the SVLK, help provide feedback for its improvement and align working procedures for independent monitoring. Statutes, codes of conduct and 'working standards' for monitoring have been developed, and the EU has provided financial support. JPIK is intended to serve as a means of providing recognition for civil society monitors and as a clearing house for reports so that feedback and suggestions can be coordinated. JPIK also remains actively involved in the ongoing process of revising the SVLK.

\section{Regulation P.02/VI-BPPHH/2010 (Annex on} Independent Monitoring) states that the process 'may include forestry observer NGOs with an Indonesian corporate body, the community living inside or around the area where licence holders or owners of rights of forests are operating, and other Indonesian citizens who are concerned about the forestry sector'. Anyone who carries out independent monitoring for the SVLK must be independent of both the $\mathrm{MoF}$ and private sector interests, and monitoring methods must be evidence based. This enhances public participation.

\section{Box 10. The complaint system for the SVLK}

The role of civil society monitoring is crucial in raising complaints against the systemic failures or weaknesses of the audit process; indeed, complaints have already been submitted. First, the CAB releases an audit report into the public domain. A civil society organisation or a member of the public can then access and review the report, and submit to $\mathrm{CAB}$ an objection concerning the legality of a certificate. To resolve objections, the CAB will establish an 'ad hoc team ${ }^{\prime a}$ to assess whether the auditor has followed correct procedures. The resolution and improved report will be submitted to the decision-maker ${ }^{b}$ as a basis for making a decision. A paper-based decision will be sent to the auditee within 10 days. If improvement is needed, the auditee is given 10 days to respond to the objection. If the CAB cannot settle the objection, civil society can request KAN to adjudicate the complaint based on its complaint resolution system. If the objection is found to be valid, KAN issues a Corrective Action Request (CAR) to the operator. If it fails to fulfil this request, its certificate will be frozen; if an auditor fails to meet accreditation standards, KAN will revoke its accreditation. Regulation P.02/ $\mathrm{VI-BPPHH/2010}$ also allows for a 'special audit' to be carried out to investigate a complaint; the cost is charged to the licence holder.

The CAR system is similar to the validation process under the VCS system for accreditation of forest carbon projects. This requires 2 independent validating officers, one of whom is appointed by VCS and the other by the project developer. These approvals are based on experience with similar work.

a As an ISO-accredited body, it would have an appropriate complaints mechanism.

b A 'decision-maker' is a staff member of the CAB, qualified and appointed as a decision-maker for 'performance assessment'. 
Concerns raised about the system include the limited scope and capacity of civil society to provide a comprehensive check on the system. In practice, individuals may encounter problems with accessing the information required and, although many JPIK members already work together, much effort is needed to systematise monitoring methods, build capacities of various groups and ensure access to information (EU-Indonesia FLEGT VPA Experts 2010). There are also concerns that civil society independent monitors will predominantly be expected to point out procedural flaws and not to provide feedback on wider issues within the forestry sector.

Experience with civil society monitors in other countries suggests that NGO watchdogs can be crucial in maintaining pressure on, and oversight over, the verification system. However, ensuring that the civil society 'watchdog' has a beneficial impact also requires that there is an adequate degree of government commitment to accountability measures and, linked to this, that attention is paid to the development of a strong domestic coalition behind the objective of the monitor (see Luttrell and Brown 2006). Without these features, the civil society monitor will be unlikely to be able to contribute constructively to system reform. A related dilemma is that the advocacy stance taken by many environmental civil society organisations can be perceived as compromising their independence and objectivity (Brown and Tucker 2006: 7).

The discussion over how to strengthen a civil society oversight mechanism for monitoring has been long and detailed in the FLEGT arena internationally (see, for example, Brown and Tucker 2006). Key lessons from this experience that are relevant for REDD+ include the following (from GoI and EU 2011e: 9, Human Rights Watch 2009).

- Guidelines for civil society monitoring must be publicly available.

- Clear requirements on the eligibility of organisations and individuals must be laid out to ensure impartiality and avoid conflicts of interest.

- Civil society must be able, in practice, to access the information needed.

- There must be provision for unannounced checks.
- Information on procedures for submitting objections and redress mechanisms must be made publicly available.

\subsection{Ensuring access to information}

The effectiveness of the SVLK (and the VPA) depends heavily on the assumption of accessibility and transparency of information and functioning systems to provide this information. These requirements represent an opportunity for reform, but their stringency may prove a weakness of the system as it will make fulfilling the requirements difficult.

Transparency is an important principle in REDD+ and a fundamental design feature to ensure the success of measures for tackling illegal logging because it enables a wider range of individuals and organisations to engage in oversight. By contrast, lack of access to information and absence of transparency of decision-making are key weaknesses that may foster the development of corrupt practices (Dermawan et al. 2011). For example, many instances of joint enforcement sweeps against illegal logging are said to have resulted in unlawful appropriation of timber by OHL personnel or associated timber brokers. Confiscated timber was often auctioned off before the courts could determine its legal status, and there were allegations of extortion by agencies (Wells et al. 2007: 6). Such practices could occur because of the lack of transparency over procedures and protocol for OHL and lack of transparency over the use of funds from the auctions.

The effectiveness of the SVLK (and the VPA) depends heavily on the assumption of accessibility and transparency of information and functioning systems to provide this information ${ }^{17}$. As a result, the SVLK has put in place a number of mechanisms to ensure access to information; the VPA has additional data access requirements (GoI and EU 2011a). These requirements represent an opportunity for reform, but their stringency may represent a weakness in the system design as it will make fulfilling the requirements difficult. Problems with accessing key data from the MoF have long been highlighted (see

17 The new SVLK Regulation No 38 is expected to address some of these concerns. 
Wells et al. 2007: 1). For example, Forest Watch Indonesia found it difficult to access the GIS database of wood-processing industries (Industri Primer Hasil Hutan Kayu; IPHHK) and the data on forest cover managed by Baplan (Brown and Stolle 2009). The problem of data sharing arises not only amongst sectors at the national level, but also at the district and province levels, with challenges in convincing governments at these levels to share maps, details on local licences and felling permits for nationally licensed units (Brown and Stolle 2009).

Some recent positive changes in access to information are evident in the sector, including the following.

- The 2010 Freedom of Information Act led to MoF Regulation No. P.7/Menhut-II/2011 on Public Information Service within the MoF, which stipulates that requests for information held by the MoF must be addressed to the Director of the Centre of Public Relations in a one-door policy whilst further guidance is being developed. Discussion related to requirements for the VPA has fed into the details of this regulation.

- An online tracking system for transport permits has been somewhat effective, and timber reports are now available online on a concession-byconcession basis.

- The online tracking system also reports on forest royalty fees (Provisi Sumber Daya Hutan; PSDH) and the reforestation fund (Dana Reboisasi; DR).

- The MoF has launched an online database with an interactive map that provides information on forest class function and current status of FMUs. However, it is encountering problems related to synchronising database collections across the MoF.

- The SVLK has built transparency into the design of the system, which may be relevant for design of REDD+ systems in several ways (Box 11).

Some concern has been raised, however, about the lack of clarity in the guidelines in Regulation P.02/VI-BPPHH/2010 in relation to procedures for gaining access to information. In addition, information listed in the new Regulation No. P.7 (on the MoF public information service) is only aggregated information, which is not sufficient for independent monitoring purposes. Therefore, for
Box 11. Examples of transparency in the SVLK

- A requirement that, along with the audit result, the Conformity Assessment Bodies (CABs) 'must publish any certificate issued, revised, suspend and revoked ... in mass media and website of the Ministry' shortly after the decision is made (Regulation P.02/VI-BPPHH/2010: IV.A.5). To date, however, no information on operators that 'do not pass SVLK-PHPL or SVLK-VLK' is available on the MoF website, nor is a consolidated certificatetracking database.

- The development of specific mechanisms for both parties to access key forestry-related information and to ensure information is available for monitoring by civil society.

- The establishment of provincial forest information centres to improve the availability and transparency of information. These are particularly important as many - predominantly small-scale licences are issued locally, and information is not automatically collated at the national level.

the purposes of the VPA, special mechanisms would need to be established to enable access to information held by different sectoral and decentralised institutions. Indeed, the text of the VPA indicates that the government of Indonesia has made a strong commitment to putting forest-related information in the public domain ${ }^{18}$ (see VPA Annex IX). Early analysis of Presidential Instruction No. 10/2011 regarding the moratorium limiting the issuance of licences for forest conversion or development of peatland suggests that the data used to produce the maps of primary forest and peatland cannot be independently verified using publicly available data (see, for example, Wells and Paoli 2011).

A crucial element if the REDD+ MRV institution is to operate effectively is a mechanism to ensure that it can access all necessary data in a timely manner. The challenge is threefold, with a need for: (1) improvements in the quality of the available data; (2) mechanisms for data sharing

18 For example: (1) Article 16 states that reporting will include cases of non-compliance and any action taken to deal with them as well as the number of cases that involved consultations; (2) the proceedings of the JIC and the results of the monitoring and evaluation of the VPA will be published; (3) an Export Licence Information Unit in the MoF will allow exchange of information between EU competent authorities and Indonesia's licensing authorities. 
and for transparency both within and amongst institutions; (3) data and information to be publicly accessible in an understandable and independently verifiable format. ${ }^{19}$

\subsection{Matching MRV system design to available capacity}

Matching system design to available capacity is a common principle for both processes. Lack of capacity is a contextual factor that needs to be considered in the design of any new mechanism. Given the rapid pace at which both processes are advancing, the capacity-building requirements across sectors and levels of government, the private sector and civil society are huge.

One of the lessons from illegal logging measures is the importance of matching system design to capacity. For example, designing a civil society monitoring system on the assumption that total information will be available may be risky in the short term and may prevent monitors from conducting their activities. Equally, designing REDD+ systems that take into account the context of weak enforcement and known failings in the legal system will help to avoid paralysis of the process in the short term. Political will aside, the capacity of government, the private sector and civil society to cope with new mechanisms, regulations and changing market requirements is an issue for FLEGT, and will be for REDD+. Lack of capacity is thus a contextual factor that needs to be considered in the design of any new mechanism.

Various recent reviews of the SVLK-VPA process have raised concerns about the lack of capacity and the need for competent institutions and staff members, who need to be appointed and trained to ensure that procedures are followed (AgroIndonesia 2010, EU-Indonesia FLEGT VPA Experts 2010). Given the rapid pace at which the process is advancing, the capacity-building requirements for meeting their needs are huge (interview with JPIK member 2011). With SVLK timber already on offer and new companies being verified every day,

19 Indeed, the MRV system outlined in the REDD+ Strategy includes the obligation to inform the public (GoI 2010). This will require clearly defined confidentiality rules. the tasks for civil society are multiplying. Some observers have pointed out that, as there is currently insufficient capacity amongst qualified verifiers, finding individuals who are clearly free of a conflict of interest, as required, will likely prove difficult. Many of the few qualified verifiers in Indonesia have close ties to the private sector. The capacity-building needs of REDD+ are particularly important because measuring carbon flux is significantly more complex and technologically demanding than tracking timber. The VCS system has encountered related problems, with the system being delayed by the shortage of accredited validating officers with sufficient expertise to fulfil the criteria required.

\subsubsection{Capacity for enforcement and due process in the legal system}

Significant weak points in terms of capacity for implementing illegal logging measures and REDD+ are enforcement, sanctioning and weakness of the legal system.

Effective implementation relies on effective law enforcement. Law enforcement is a primary tool for tackling those aspects of illegal logging that traderelated measures such as the VPA cannot address. However, weaknesses in enforcement, sanctioning and the legal system (reportedly hampered by manipulation of investigations and the lack of written judgments) constitute significant weak points in terms of capacity for implementing illegal logging measures.

One finding from the CIFOR Integrated Law Enforcement Approach project was the importance of engaging with enforcement agencies for the success of an initiative (CIFOR 2011). However, the same project showed that the information flow and coordination amongst enforcement agencies are poor, that the police are not motivated to enforce laws and that judges have no experience in dealing with new legislation. Further complicating this situation are changes to how illegal logging functions; whereas in the past it was openly illegal, perpetrators are now increasingly able to get permits (such permits, although technically legal, are issued via means in direct violation of the law). Although the number of illegal logging cases brought to court has declined (Table 2), most of those convicted are believed to be 
small-scale operators or 'foot soldiers', rather than the main masterminds of illegal logging crimes (Detik News 2005). This raises further questions about the effectiveness of prosecuting illegal logging cases in Indonesian law courts.

In high-profile crackdowns in Kalimantan and Papua in 2005, codenamed 'Operation Sustainable Forest II' (Operasi Hutan Lestari II or OHL II), 186 people were arrested, including 18 senior military and police officials. Whilst the government claims it spent more than US\$1 million on the operation, only 13 people were ultimately convicted of any crime, with the longest sentence being 2 years (Human Rights Watch 2009). Furthermore, those illegal logging operators brought to court were either released or given symbolic sentences as illegal logging was viewed as an administrative rather than a criminal offence.

Most cases of illegal logging in Indonesia are dealt with under Law No. 41/1999; therefore, the law enforcers usually focus only on administrative aspects - that is, only on the existence of permits despite much evidence showing that corruption occurs in the issuance of permits. Consequently, most of the perpetrators caught and punished are small-scale operators. The maximum fine for forestry crime under the forestry law is only Rp 10 billion (approximately \$US1.2 million); therefore, in many cases, this does not lead to recovery of state financial losses from larger-scale perpetrators (Santoso et al. 2011).

Article 50(2) of Law No. 41/1999 creates an avenue for law enforcement agencies to go beyond 'legality' in tackling forest crime, hence increasing their chances of catching the 'bigger players'. Article 50 defines destructive logging as a forest crime even if the operator holds a legal logging licence and prohibits concession holders from conducting any activity that may result in forest destruction. When law enforcement agencies suspect a concession holder of illegal activity, they can focus on proving that its activities have resulted in forest destruction. However, this legal provision is rarely used. This concentration on administrative rather than criminal aspects will also prove a serious barrier for the implementation of REDD+, in which enforcement in relation to the legal process for changing land use allocation (e.g. forest estate to plantation) is a highly pertinent issue.
Box 12 describes a case in which law enforcement agencies claimed that there was no basis to investigate certain companies as the concession was legal and had not violated any laws - even though the district head had been convicted of corruption during the permit-granting process. This case illustrates the failure of law enforcement agencies to investigate and prosecute under Article 50(2) of Law 41/1999. The failure to bring legal proceedings against illegal logging offenders is often rooted in the ambiguities in the forestry laws, which make them open to varied interpretation (Box 12). Fundamental concepts such as forest, degraded forest and related criteria and indicators are poorly defined; various forestry actors whose interests are threatened can exploit this lack of clarity to deflect criticism.

\subsubsection{Strengthening or duplicating existing systems?}

Developing one all-encompassing MRV system will help to ensure efficiency, transparency, accountability and complementarity between countries and avoid duplicating (or worse, undermining) existing systems. MRV design must avoid undermining existing national processes and strategies. An MRV system for REDD+ should prioritise the country's broader needs for a crosssectoral MRV system for carbon emission reductions as well as the need for international credibility.

Although the success of REDD+ will ultimately be measured in carbon emissions, monitoring performance in relation to governance, particularly in the earlier phases, serves needs at both domestic and international levels (Box 13). In this way, MRV for REDD+ serves 2 functions: (1) to meet international standards and ensure international credibility; and (2) to help improve national policies, frameworks and enforcement strategies to ensure greater accountability to national stakeholders (Saunders and Reeves 2010: 46).

Concern over the need to comply with minimum international standards has led to proposals both to create new national REDD+ MRV agencies and to reform to the existing ones. Developing one all-encompassing MRV system to perform both these functions could help to ensure efficiency, accountability and complementarity amongst countries. As well as adopting fund-based 


\section{Box 12. Barriers to getting convictions in high-level illegal logging cases: An example}

The widely publicised alleged illegal logging case in Riau between 2007 and 2009 offers an illustration of why most efforts to prosecute high-profile offenders for illegal logging crimes often end in failure. In 2007, the newly appointed police chief of the province of Riau received a report prepared by a local NGO, Jikalahari, which outlined in great detail alleged widespread violations by several forestry companies associated with the RAPP and Indah Kiat pulp and paper mills. The chief, wanting to build a reputation as an incorruptible law enforcer, decided to act. In January 2007, he approached a number of well-regarded forestry scientists at Indonesian universities to form a panel of experts to assist with the investigation of illegal logging in Riau. By mid-2007, this panel of experts, in collaboration with the Riau provincial police, identified 14 forestry companies which, in the panel's view, had committed gross violations of forestry laws. Amongst the key accusations were that logging beyond the permit area and forest clear-cutting were unlawful (according to the panel's interpretation, the companies' HTI plantation permits did not permit any felling of natural forest) and that logging operations were carried out even though the licensing process had not been finalised. Based on the investigation, in 2008 the Riau police identified nearly 200 suspects (amongst them 53 pulp and paper mill managers, 30 forestry agency officials, 20 licensing officials and 4 consultants), including several former district heads. One district head, Asral Rachman, was prosecuted and convicted; he was sentenced to 2.5 years in prison with a Rp 85 million (US\$9000) fine for corruption in issuing plantation permits. In mid-2008, whilst this case was under way, the driving force behind the investigation (the Riau police chief) was transferred to Semarang, Java.

In early 2009, the MoF took steps to present its version of alleged illegal logging events in Riau. The MoF denied that plantation development practices by the 14 operators were illegal. It argued that conversion of degraded production forest is allowed for timber plantation establishment, but that the definition and verification of the state of degradation are subject to interpretation. Furthermore, the clearance of natural forest did not change the status of the area; that is, the area retained its function as forested area because it was planted with Acacia and Eucalyptus seedlings. Finally, the incomplete status of the HTI permits was viewed as an administrative infringement rather than a criminal offence. In mid-2009, the new Riau police chief officially terminated the illegal logging investigation, citing lack of evidence.

Source: Jakarta Globe (2011a, 2011b)

mechanisms, several REDD+ project proponents are trying to sell voluntary carbon units (VCUs) through the voluntary carbon market, but including these in a cross-sector MRV system is more problematic. However, REDD+ initiatives could avoid duplicating (or worse, undermining) existing processes by aligning with other economic, climate (e.g. Nationally Appropriate Mitigation Actions [NAMA]) and spatial planning processes at all levels (discussed in Wibowo 2011). Regardless of the institutional design, the relationship between a REDD+ agency and the sectoral road maps and strategies remains unclear. Key challenges are to avoid allowing REDD+ to dominate broader national priorities that should be captured in the NAMA, and to ensure that its carbon emission objectives are synergistic with other national objectives.

Brown and Peskett (2011) point out the proliferation and fragmentation of climate financing initiatives in Indonesia. Engagement in bilateral negotiations on REDD+ by certain sectors of the government of Indonesia (e.g. Ministry of Forestry, Ministry of Environment) increases the risk of the REDD+ process in Indonesia becoming more disconnected from the national plan for the NAMA, which is outlined in the Second National Communication. One concern, for example, is that the LoI is undermining existing initiatives and bypassing government systems by creating new institutions (Bappenas official personal communication 28 April 2011). Furthermore, it is not clear how the REDD+related MRV institution will link with the national system for GHG inventories (named SIGN, and now under development) or with the Monev system. Another concern is that an MRV system designed solely for the LoI will have international credibility as its primary aim and thus may fail to prioritise the country's broader need for a cross-sectoral emission reduction MRV system (Brown and Peskett 2011: 27). In reality, REDD+ financing makes up only a small part of all climate-change-related financing, especially if concessional loans are included in the calculation (Brown and Peskett 2011). It could 


\section{Box 13. Complementarities and contrasts between international and national MRV needs}

International needs relate to maintaining the credibility of a REDD+ mechanism. One way to do this is through a national monitoring and reporting framework that can show progress towards reducing emissions, underpin a performance-based payment system for REDD+ and ensure meaningful accountability to international stakeholders. National needs arise mostly in terms of achieving reforms in the land use sector, implementing safeguards dealing with the complex political and economic incentives that have resulted in high levels of deforestation and degradation, and ensuring meaningful accountability to domestic stakeholders.

Source: Saunders and Reeve (2010)

be argued that, logically, the NAMA should be developed first and the REDD+ Strategy then fit into it, but there has been little attempt to link them. The problem of institutional silos and the risk that REDD+ could increase fragmentation of action are very real (Brown and Peskett 2011). Other observers have gone further, suggesting that the institutional duplication involved in the SVLK process might lead to 'double costs' and an institutional environment that 'enriches' corrupt behaviour (Maryudi in Cashore et al. 2010). Establishing synergies with the SVLK and the ongoing process of refining this legislation could contribute to attempts to avoid this. Indeed, failing to establish such synergies with the REDD+ process or duplicating similar structures and processes risks negating any gains made under the FLEGT-VPA process and undermining the FLEGTrelated structures.

\subsection{Avoiding unintended impacts}

Avoidance of leakage and displacement, and management of unintended impacts, are key areas of concern for REDD+. Measures to address these concerns are also measures to tackle illegal logging. Concerns include the risk of emissions increasing elsewhere, the shifting of markets for illegal timber to less stringent buyers, negative impacts on livelihoods and the exclusion of smallscale operators due to high transaction costs. Displacement can occur at a number of scales, from the project to national and international levels.
Leakage and displacement of carbon emissions are key areas of concern for REDD+. Concerns have also been raised about the unintended impacts of the measures for tackling illegal logging (such as log export bans) and how to prevent impacts shifting elsewhere in time and space. Displacement can occur at a number of scales, from the project level up to national and international levels. Both REDD+ (whether under the UNFCCC framework or voluntary carbon markets) and FLEGT have explicit requirements for addressing unintended impacts, be they an increase in emissions elsewhere, the shifting of international markets for illegal timber to less stringent buyers, negative impacts on livelihoods or the exclusion of small-scale operators due to high technical and financial barriers to entry.

One of the main leakage issues facing REDD+ pilot programmes in the short term is how to prevent leakage outside of the project area. Project design currently addresses this by defining leakage belts and measures to mitigate leakage. A parallel issue for measures addressing timber legality is how to avoid the pressures for legality assurance leading to an increased supply of wood from illegal or unsustainable sources (MacDicken 2010). The case in point is timber from forest conversion, which currently can be licensed under the SVLK. Since a significant proportion of timber processed annually in Indonesia is conversion timber and large-scale plantation expansion in the forestry and agriculture sectors is expected in comings years, there is a danger that timber from unsustainable sources will become a major product on the European market (Wells et al. 2007). This could reduce incentives for more costly timber verification in forest areas. As part of the solution to this, under the VPA, the Indonesian government has committed to using its SVLK to verify the legality of all exports, regardless of whether they are destined for the EU (GoI and EU 2011a).

Another form of leakage is international leakage, a concept that the UNFCCC currently ignores. It is, however, a significant problem in the form of cross-border trade of illegal logs, particularly in Southeast Asia. In terms of the VPA, there is a risk that the export market may shift away from highrisk European countries to 'less risky' countries with less stringent requirements, such as China and 
India, although this would require adjustments to timber products exported to these countries. (China and India favour unprocessed or roughly processed timber) Indeed, in the case of oil palm, for example, there is some suggestion that Sinar Mas may have redirected some of its investment in oil palm to Liberia and other countries in Africa because of the difficulty in obtaining new licences in Indonesia (Jakarta Globe 2010). Similar risks threaten the prospects for REDD+.

The big question for private sector operators is whether it is worth bothering with legality compliance or whether doing so risks putting them out of business. In theory, the cost of compliance for legal producers will increase, but the cost of corruption will fall, with reduced opportunities for illicit payments. However, the converse logic may apply: reduced opportunities for illicit payments may lead to an increase in the cost of corruption, that is, when there are many entry points for corruption, the cost is low because of competition amongst receivers.

Local livelihoods and the poor constitute an area of serious concern in terms of unintended impacts. Article 12 of the VPA states that:

Parties agree to develop better understanding of the livelihoods of potentially affected indigenous and local communities ... The Parties will monitor the impacts of this Agreement on those communities and other actors ... while taking reasonable steps to mitigate any adverse impacts.

Enforcement of forest laws can also adversely affect the poor. In the case of the enforcement sweeps (OHL), the arrests largely netted ground-level operators - predominantly poor locals with limited options for earning an income - thus negatively affecting local livelihoods (Colchester et al. 2006) and criminalising 'needs-based' logging. Local communities are often the targets of enforcement sweeps because they tend to have no legal certainty. This raises the concern that local communities, rather than the 'big drivers', are targeted, with the risk of smaller-scale actors being criminalised. One example of this is the way in which local communities became a key target of the OHL enforcement sweeps, including in MoF's unilateral cancellation of provincial community-logging licences (IPKMA) in Papua. In the case of the IPKMA, the OHLs were successful in stopping smuggling syndicates from using the permits to access and launder timber, but these permits were the only legal means for communities to generate income from timber on customary lands and the OHL removed any chance for community management of natural forest timber (MFP 2006). A new anti-illegal logging law being debated in the parliament as of September 2011, because of its greater focus on the application of anti-corruption and financial crime measures, could presumably reduce the current bias towards penalising ground level operators rather than those who plan and orchestrate the illegal activity.

A related problem facing both REDD+ (as seen in voluntary carbon projects) and the legality verification process is that of high technical and financial barriers to entry and the need to avoid excluding small-scale operators from market access. One method being explored in the case of REDD+ projects is the bundling of projects to achieve economies of scale (Bradley 2010, Poffenberger 2010). 


\section{Multi-stakeholder process and ownership}

\subsection{Addressing sovereignty concerns}

One of the key challenges for REDD+ is how to meet international demands whilst creating national ownership over the process. A key element blocking progress of the REDD+ debate in Indonesia is the widely held perception that the mechanism will undermine sovereignty and the interests of the national economy. Demand has been important in dealing with low national ownership in the VPA process, which suggests the importance of adopting an approach that tackles both supply and demand.

One of the key challenges for REDD+ is how to meet international demands whilst creating national ownership over the process (Abrahamsen 2010). Why is this important? Cashore and Stone (2010) suggest that governments may be resistant if they are 'forced' to take part in efforts which they otherwise might not have, but that they are likely to be supportive if the process is focused on helping them to achieve their domestic targets. Indeed, a key element blocking progress of the REDD+ debate in Indonesia is the widely held perception that the mechanism will undermine sovereignty and the interests of the national economy. The VPA process met with similar resistance (as the quote below shows). One of the main issues challenging sovereignty is the requirement for 'third-party monitoring', which adheres to the EU's own requirements for independence. Experience of how this resistance was overcome is illuminating, particularly with regard to the attention to local ownership of the process, realistic time frames and the need for demandside measures.

Some NGOs don't agree with the VPA and some of them also have their international networks through which they can ship their not entirely true information... These NGOs feel that the $\mathrm{EU}$ is imposing a VPA on Indonesia, rather than thinking that this is a way for Indonesia to improve international relations, clarify laws and improve governance. (Telapak 2010 quoted in van Heeswijk 2010: 108)
In the case of REDD+, the LoI financing, for example, is associated with an emphasis on performance in terms of process and institutional reforms. However, concerns have been raised that performance-based systems will not necessarily work in this context (Human Rights Watch 2009: 69). Experience teaches that conditionalities rarely work, especially in a country such as Indonesia where international donors have relatively little influence: Indonesia graduated from the IMF (International Monetary Fund) programme in 2006 and overseas development assistance accounts for less than 5\% of the total national budget (A4DES 2010: 67-74). For example, the 1998 IMF rescue package for Indonesia was made conditional on forest reforms but these conditions were never met (Human Rights Watch 2009). Luttrell (2007) suggests that verification systems designed to address national priorities and complement the structure of national institutions engender a higher level of ownership than those based on donor conditionalities or access to international markets.

The Indonesian Parliament has not yet offered clear support to the moratorium or to the LoI, in particular its financial clauses (Rema 2010). The 2 key interlinked criticisms are related to the impact on the economy, and business in particular, and the associated threat to national sovereignty. As a result, many members of Parliament have moved against the moratorium (Mustaidah 2010, Kompas 2011, Kusumaputra 2011, Mauladi 2011). For several reasons, the reforms associated with REDD+ continue to be largely externally driven processes and agendas, which are not perceived as necessarily being in the best national interest. These reasons include:

- the linking of the proposed reforms and REDD+-related activities to bilateral discussions over financing, particularly those associated with the Norwegian LoI;

- the linking of these debates with Indonesia's positioning on the international stage, particularly at COP meetings and the 
Subsidiary Body for Scientific and Technological Advice (SBSTA);

- the performance-based nature of the LoI discussions, which may create a perception of the LoI as conditionality;

- deadlines for REDD+-related processes such as the introduction of the moratorium and the writing of the REDD+ Strategy were set by the LoI and monitored by Norway;

- the focus on the need for independent, and possibly international, verification;

- the perception that countries involved in bilateral discussions are motivated by benefits to their own economies, as an attempt to lead the way to a global agreement and/or to secure 'cheap offsets';

- the challenges to 'business as usual', which represent a possible threat to industries such as the palm oil industry and which are driven by geopolitical economic competition; and

- the risk that REDD+ may not compensate the full costs (formal and particularly informal) incurred by those affected.

In many ways, the task is easier in the case of the bilateral VPAs where the nature of the market (including regulations in other countries) provides an excuse to address governance issues rather than the previous tendency of UN processes to impose 'one size fits all' requirements. However, COP 16 in Cancún moved beyond earlier preoccupations with seeking a comprehensive climate change agreement by encouraging the value of reaching consensus over clusters of issues. One technique, used under the VPA process, and which could possibly be used in REDD+, was the formation of joint committees between bilateral partners, as such committees create a forum in which sensitive governance issues can be addressed more easily.

The VPA process stalled from the end of 2007 until 2009 because of a perception in both the government and the private sector that the EU was not taking it seriously. On 20 October 2010, the EU Timber Regulation was signed, which opened the way for further progress on the VPA:

Now the process is taking up speed again because of the Due Diligence regulation. The government is basically following this, because they want to keep market access to the European Union.... The main reason for Indonesia to be involved in the VPA process is to continue market access (WWF Indonesia 2010 quoted in van Heeswijk 2010: 102).

The lesson for REDD+ from this vital factor of 'demand' is that building ownership requires regulations that guarantee a market. Demand was an important part of the solution for the VPA. In the absence of a compliance market, the aspect of demand is more problematic for REDD+. However, hope lies in the potential bilateral agreements with Australia, Japan and possibly South Korea, and hence access to these domestic markets in the region. There is also a small but growing demand in the local corporate social responsibility (CSR) market (see, for example, Garuda Indonesia 2010). Alternatively, in the absence of a strong demand mechanism, it may be necessary to concentrate on building and strengthening a national and public constituency for REDD+-related reforms.

\subsection{Pitching incentives at the right level: Incentivising local government}

REDD+, as with many illegal logging measures, is a centrally designed process that requires implementation and monitoring at the local level. The role of local government is often unclear. This raises the challenge of how to set appropriate incentives to build ownership, accountability and capacity at the local level, particularly in local government. A key aspect needing resolution is how to accommodate jurisdictional differences within a national system, particularly in areas under special autonomy.

A key challenge for both REDD+ and FLEGT-VPA is how to address problematic incentive structures in a decentralised system, a system that in many cases actually exacerbates problems of illegal logging. Both initiatives (as well as many other illegal logging measures) are centrally designed processes that require implementation and monitoring at the local level. FLEGT and REDD+ have been accused of masking attempts at recentralisation and top-down decision-making; reports suggest some suspicion towards REDD+ on the part of local government and therefore challenges in terms of 
getting support at decentralised levels. The SVLK has encountered a similar problem, as illustrated in the following quotes.

From what I am feeling, and the things district officials are saying this, the SVLK is a Jakarta-toy. These officials say 'let them do what they want and we do what we want'. I think there will be strong resistance from the provinces and districts. This could be very ineffective and therefore, I am not very optimistic about the situation (WWF Indonesia 2010 quoted in van Heeswijk 2010: 104).

One of the motives of Indonesia to negotiate a VPA is to regain power. The VPA provides a mechanism to regain control over lower governments and shift control back to the central government (DG Environment 2010 quoted in van Heeswijk 2010: 78).

This raises the crucial challenge of setting appropriate incentives to build ownership, accountability and capacity at the local level, particularly in local government.

Decentralisation is said to have facilitated the expansion of illegal logging. Illegal practices increased during the early years of decentralisation following the fall of Suharto (Obidzinski and Barr 2003, Barr et al. 2006, Colfer et al. 2008), encouraged by the euphoria of self-governance, administrative confusion and a breakdown of established forestry controls. In many parts of Indonesia, logging rights were issued indiscriminately, regional by-laws allowed for direct log exports and timber smuggling was rampant (Obidzinski and Barr 2003, Tokede et al. 2005). Since 2002, however, the MoF has adopted measures to rescind much of the authority over forest administration that had originally been transferred to the districts (Barr et al. 2006: 2) and the ministry 'reasserted its own authority by issuing numerous forest conversion licenses for plantation development and by renewing the contracts' of large-scale timber concessions (Barr et al. 2006: 14). However, the central ministry does not always have the de facto authority to enforce such powers, as many local administrations 'continue to issue their own permits anyway' (Human Rights Watch 2009: 12). In addition, 'district governments have retained considerable discretionary power in other sectors' so the central government has the power to issue concessions but the district has the authority to issue location permits and plantation licences. This means that 'control over land for investment purposes continues to be mediated by the local state, ensuring investors have to negotiate control of the land in the local domain first before proceeding to process the concession licence in Jakarta' (McCarthy 2010: 104).

The result is that various pieces of conflicting legislation regulate the concession licensing process, many of which are contradictory in terms of the discretion left to local government. For example, local government is responsible for licensing smaller mills (capacity of less than $6000 \mathrm{~m}^{3}$ ). Related to this, there are significant tenurial uncertainties over land, forest and carbon that need to be resolved to clarify REDD+ benefit sharing. The audit of the forestry sector conducted by the KPK in 2010 highlighted the abuse of forest licences stemming from these vague regulations (Jakarta Post 2010a, Kompas 2010c). Other analyses of the impact of decentralisation on forests in Indonesia indicate a strong link between illegal logging and local political power networks (Casson and Obidzinski 2002, Obidzinski and Barr 2003). For example, timber has long played - and continues to play - an important role in financing local political processes (Burgess et al. 2011, Purnomo 2011), although recently, timber as a source of political finance has been superseded by mining and commodity plantations, especially for oil palm and pulp and paper.

A lesson emerging from FLEGT-VPA processes in other countries is that it is necessary to pitch incentives at the right level (Saunders et al. 2008). Weak coordination and supervision between levels of government mean that provinces do not routinely audit the activities of districts, and districts do not have the capacity to oversee field officers, many of whom do not have the resources or incentives to carry out their responsibilities (Brown et al. 2008: 181). One example is the way in which joint enforcement sweeps such as the OHL have been accused of undermining existing MRV systems at the local government level because of the limited involvement of local government and treatment of local government licensing as a criminal rather than an administrative matter (when the allocation 
of licensing between central and local government remains in dispute). The OHL system included no clear standards or procedures for evaluating decisionmaking and imposed criminal sanctions (Wells et al. 2007: 6).

The SVLK lacks clarity in terms of the role of locallevel forestry officials in monitoring, specifically in relation to how provinces and districts communicate non-compliance to CABs and the licensing authorities (EU-Indonesia FLEGT VPA Experts 2010: 12). Again, this raises the question of how the SVLK, in its current design, can help address monitoring and oversight deficiencies at the local level. Although there are advantages to removing from this level of government any authority over the verification of operator compliance, it may also be problematic: 'as long as the responsibilities of local government are not matched by authority, they will have little incentive for monitoring and control' (Brown et al. 2008: 185).

Similarly, the current REDD+ Strategy shows a clear preference for a national top-down approach to MRV: the task of the MRV institution at national level is to monitor MRV indicators nationwide, whereas the role of the MRV institution at subnational level includes clarification or ground checking of the results of measurement at national level (GoI 2010: 47). A number of institutions are working on setting RELs but these are mostly at subnational level; there are no clear mechanisms for sharing, collecting or integrating data nor any clear responsibility for disaggregating data from subnational to national levels or deciding the approach and methods (Boer 2010: 26). Furthermore, there has been very little debate on what is needed to regulate the subnational MRV system or on the related roles and responsibilities of government agencies at different administrative levels.

An important element in incentive structures for local government is a transparent MRV system for accruing and sharing revenue. Such a system is necessary both for land rents received from ERCs (Ecosystem Restoration Certificates) and for the forest carbon net revenue. Some positive changes have occurred in this respect, such as increased transparency in forestry sector levies (PSDH and $\mathrm{DR})$ through their inclusion on the online tracking website. This might serve to strengthen incentives for monitoring and control by the local governments that are entitled to a proportion of these levies, as well as providing useful information for public oversight. Previously, it was difficult to predict how much local government was entitled to; this lack of predictability encouraged the imposition of local taxes on operators, thus increasing the costs of legal compliance (Wells et al. 2007: 29).

Questions about jurisdictional accounting have recently emerged in REDD+: what form should the nested approach take, at what level will activities be credited and what level is liable? These issues are related to questions such as whether governments should be credited for reduced deforestation within their jurisdiction if such reduction is not the result of a geographically specific project activity. A related issue is how to accommodate jurisdictional differences in areas such as Papua and Aceh, which are subject to the 2006 Law on Special Autonomy. Many REDD+ hotspots (in terms of forest cover) are situated in regions in provinces with special autonomy. REDD+ therefore raises questions about how the law may allow for different levels of retention and distribution of funds. Under legality verification, questions may arise as to whether, under the Special Autonomy Law, the authority for verification of operational compliance can be transferred out of the region. The UNFCCC makes no allowance for special autonomy because of its requirement for wall-to-wall monitoring.

Another issue is the effect on project-level crediting if a jurisdiction as a whole fails to reduce deforestation or increases deforestation emissions. Under marketbased illegal logging measures such as the VPA, operators that fail to comply will lose access to the market. In the case of REDD+, projects or jurisdictions may be liable for permanence and subject to some form of sanction including the loss of payments.

\subsection{Getting buy-in from the private sector}

Support from the private sector was a crucial element in reaching an agreement on the SVLK. This is a key challenge for REDD+ also: whereas some elements of the private sector are prime 
movers for innovation, others constitute massive barriers to REDD+. For the SVLK, the private sector was less interested in being involved in consultation processes than in being shown the benefits of complying and a step-wise approach. These lessons are likely to be relevant to REDD+.

The FLEGT-VPA is specifically aimed at incentivising the private sector, and securing the support of business was a crucial element in finalising an agreement. The VPA process in Indonesia initially suffered from a lack of support from this sector; being involved in the MSP was not enough to convince them. Of more relevance to the private sector was concrete evidence of the benefits of complying. ${ }^{20}$ Demonstrating the benefits of complying with the legality standard in terms of market access and price proved essential in gaining support from the business sector.

Related to the trade aspect of FLEGT, we had a strong fight between business, society, NGOs and communities.... The business wanted no other trade restrictions and the legality standard was perceived as another constraining factor at that time. The dispute took quite a long time, until we succeeded in involving the business representatives in a multi-stakeholder technical team to finalize the legality standard and its coverage (National Forestry Council 2010 quoted in van Heeswijk 2010: 114).

For REDD+, this challenge is even more acute: whereas some elements of the private sector are prime movers for innovation, those elements involved in alternative land uses such as oil palm, pulp and paper and mining currently constitute a massive barrier to REDD+. Both the private sector and Parliament have been vocal in their opposition to REDD+ and the moratorium in particular, voicing fears that jobs and industry will be affected and that it will have negative impacts on groups with vested interests in land use sectors such as oil palm, pulp and paper, mining and timber.

For REDD+, further key questions include how to develop an attractive environment and additional regulations to encourage new private sector

20 Addressing this particular issue is the objective of the VPA's planned market monitoring facility. investment. The FLEGT-VPA is based on established markets, whereas REDD+ requires attracting a whole new set of operators to the forestry sector as well as changing the activities of existing operators. The emerging nature of the market means that many operators are reluctant to share information about their activities. The processes also differ in terms of the nature of the risk for the private sector. For REDD+, under a compliance market or a bilateral agreement, the onus for performance will fall on the government. Under the VPA system in Indonesia, it falls on the individual operator.

One of the challenges for REDD+ is how to incentivise the first movers in the private sector, for example, to ensure that existing projects which have been operating under voluntary market standards are fully integrated into a national REDD+ system. In the design of the VPA, particular attention was paid to phasing in operators certified under other certification systems by guaranteeing that they would not be subject to further verification until their current certificates expired (GoI and EU 2011c: 23). Thus, one of the ways in which both the weak will of the private sector and the capacity deficit have been tackled is by embracing the concept of the step-wise approach. To this end, emphasis has been placed (including by dominant civil society players such as Telapak) on not pushing reform or raising expectations too quickly. For example, many stakeholders in the early discussions on standards pushed for 'fully sustainable' to be a precondition for legality. However, there is a danger that the private sector will disengage from the process (and this includes REDD+) if the costs of doing business are too high, if potential tax burdens throughout the investment cycle are not clarified and if regulatory burdens are too onerous and rule changes too frequent. In adopting a step-wise approach, the SVLK required that operators, at a minimum, 'ensure legality for timber production but are encouraged to move towards fully sustainable forms of timber production' (GoI and EU 2011a). Some observers have noted that this is in contrast to REDD+, where the process is being pushed relatively quickly. It is argued that, rather, a gradual process is necessary for REDD+, in order to build the capacity of producers, oversight agencies and certification organisations (Hafild 2010). However, step-wise approaches can create a trade-off with credibility, leading to 
accusations of being 'too accommodating' and open to misuse by unscrupulous operators.

\subsection{The design and role of consultation processes}

\subsubsection{The multi-stakeholder approach in the legality debate}

Some of the success of the VPA-driven legality system is attributed to the close attention to the multi-stakeholder approach, which, in the case of Indonesia, has been crucial in helping to reach a common understanding of the nature of the problem, the issues to be resolved and the choices to be made. Multi-stakeholder processes are generally important for enhancing legitimacy, effectiveness and public scrutiny - all barriers to illegal operations. However, opening up a process to multi-stakeholder involvement inevitably leads to broadening of the remit, slowing down of the process and dilution of agendas. Stakeholder consultation can delay crucial developments and raise expectations. In addition, such processes must not undermine more accountable forms of democratic representation. A clear definition of the purpose of roles and precision regarding expected results and outputs, including how the results of consultations will be used, are critical for ensuring accountability and avoiding fatigue.

The lengthy multi-stakeholder process (MSP) in relation to the legality standards and the SVLK has been a key feature of the mechanism's development (Box 14). The long process taken in developing the legality definition made it possible to identify the different roles and responsibilities of the governments, agencies and operators involved. In this section, we discuss how the design of REDD+ in Indonesia can learn from this experience. MSPs have been crucial in the development of legality assurance systems by:

- bringing additional expertise into the design of the mechanism;

- encouraging the sharing of field-level information by civil society;

- providing an ongoing oversight mechanism;

- monitoring performance;

- identifying the different roles and responsibilities of the relevant governments, agencies and operators, thus bringing clarity to decisionmaking processes; and

- facilitating consensus on key aspects.

MSPs are seen as important for enhancing legitimacy (see, for example, FERN 2010). An additional assumption is that MSPs will result in more credible and useful information and more accountable systems. For example, as development of the SVLK involved an intensive consultation period, it is assumed that the relevant stakeholders acknowledge and accept it. MSPs are valued for their function in helping to respond to any external criticism of the process and to enhance its credibility both domestically and internationally. In the case of FLEGT-VPA, market demand is closely related to international public perception, which itself can be heavily influenced by international advocacy and civil society, as described in the following.

\section{Box 14. Use of multi stakeholder processes in the development of legality standards}

Indonesia debated and revised its timber legality standard between 2003 and 2008 as part of an extensive multistakeholder process involving many consultative workshops. Initially, The Nature Conservancy (TNC) led the consultation process for developing legality standards; Telapak/EIA was another important player. In 2008, it was agreed that LEI should take over the facilitation of the process, because, as an organisation with broad national membership and technical credibility, it was better placed than TNC to take this role. The multiple initiatives were aligned. The process analysed all 'forest related liege, and regulations covering permits and social safeguards and forest management and timber production regulations, transport and trade as well as forest related fees and relevant export provisions' (Gol and EU 2011b). An ad hoc team and steering committee (established by Ministerial Decree (SK) 70/Menhut - II/2006) was set up with representatives of the MoF, private sector, indigenous groups and academics. The standards incorporated the MoF's Timber Administration System (PUHH). Field-testing of the standards was carried out in 2006, as was 'socialisation' in Kalimantan (Telapak 2007), and the standards were revised multiple times. 
What should be included in the [legality] definition depends on what the market wants. That is what will decide, if the market demands the broad definition that includes all kinds of social safeguards, the standard will have to take that into consideration. If the market demands a very narrow focus, there will be no need to have a broad definition. But it seems at least that the market and the NGOs are pushing for a quite broad standard that includes quite a lot of social safeguards and aspects which may not necessarily be included in a more narrow legality standard (FLEGT Support Project 2010 quoted in van Heeswijk 2010: 123).

The same applies for REDD+, especially when it comes to issues such as defining 'forests' and safeguards. Regardless of how the global agreement on REDD+ evolves, carbon credits generated under the mechanism at the national and/or project level will still be traded internationally and public perception will still influence their credibility and acceptance. The importance of public scrutiny is therefore a key design issue to be considered for REDD+:

The fact that you have involved multi-stakeholders from the beginning is essential. In many countries where we negotiate, law enforcement is a problem and the best thing to promote compliance with the legislation is to work with your stakeholders when you design a new system, rather than imposing it afterwards. It is not just the result of the legality definition, but the process to get this system in place (EC Jakarta 2010 quoted in van Heeswijk 2010: 14).

However, the manner in which an MSP is facilitated is crucial: attempts to keep information about the process private and establish layers of power over information will lead to distrust, particularly amongst civil society and the public. In recognition of the importance of this aspect, the VPA emphasises the role of consultation processes. For example, Article 11.1 of the VPA says: 'Indonesia will hold regular consultations with stakeholders on the implementation of this agreement and will in that regard promote appropriate consultation strategies, modalities and programmes.' The VPA negotiating team includes members of civil society, and it is expected that civil society representatives will be part of the Joint Implementation Committee (JIC).
The VPA process is giving legitimacy to the definition of legality. Without a decent process, the legality definition cannot be accepted by the European Commission (DG Environment 2010 quoted in van Heeswijk 2010: 78).

The FLEGT MSP was strong in its inclusion of civil society and business, but cross-sectoral integration across ministries, beyond the MoF, was relatively weak. As the forestry sector tended to dominate the process, the need for wider sectoral involvement quickly became apparent, for example to revise legislation outside the forestry sector such as the Ministry of Trade laws on export controls to enable compatibility of the SVLK with the VPA.

Problems encountered during the FLEGT MSP also offer useful lessons. Opening up a process to multi-stakeholder involvement inevitably leads to broadening of the remit. Civil society took the opportunity to push for reform of the forestry sector by requesting revisions of regulations, improvements in transparency and consultative decision-making, and the development of a broad timber legality standard (see Telapak 2007: 2). The MSP progressed slowly, as many of the stakeholders were dissatisfied with the process or felt that their issues were not being accommodated. For example, major differences of opinion developed amongst those involved in deciding which laws and regulations the standard should cover; such disagreements threatened to undermine the standard's legitimacy and practicality (Wells et al. 2007: 10).

There was disagreement on social issues, tenure issues and environmental issues. The NGOs wanted that all these standards should be placed in the legality standard. But if you would do so, no one could pass the standard (LEI 2010 quoted in van Heeswijk 2010: 124).

Given these trade-offs, Indonesian civil society groups were divided over whether to engage; some say they were weakened by doing so, and others have been criticised for doing so. However, many believe that it is better to get an imperfect regulation on the table (that can be refined later) than none at all; indeed, the SVLK is currently undergoing an annual revision process, taking inputs from the independent monitoring process and the CABs as well as the government. 
In terms of lessons for the REDD+ process, this experience raises questions about how to engineer an effective MSP. The answer depends on a range of factors, including the following (from Luttrell 2007).

- What is the objective of the process? It is believed that MSPs can lead to better outcomes thanks to the range of inputs they enable, the increased commitment they generate and the way they can endow a process with legitimacy and credibility.

- Is the MSP intended as an opportunity for dialogue or a decision-making forum? In terms of the legality standards, the MoF had the final decision-making power on implementation, and lack of interest by the ministry led to the process being stalled from 2007 to 2009 .

- Who has the executive and legal mandate to close, and help implement, the final decision? This aspect requires clarity on the limits of the MSP's decision-making power vis-à-vis government agencies and other democratic accountability mechanisms. Above all, all stakeholders must be aware of the limit to their powers.

Although MSPs are often viewed as a step in furthering democracy, in that they allow a wider range of voices to be heard, some concern has been expressed (see, for example, Ribot $e t$ al. 2006) that MSPs might undermine rather than strengthen democracy or existing state-society accountability mechanisms. This could occur through the contradiction of political or administrative laws, the undermining of more accountable local representation or the hijacking of the process by interest groups. This concern emerged during the early days of the process of defining the legality standard in relation to the controversy over whether an MSP has the right to decide which laws are included in the standard. To resolve the crisis, an institution with more legitimacy (LEI) was engaged to facilitate the process and formalise the protocols. A clear definition of different actors' roles and a precise description of the expected results and outputs, including how the results of the consultations will be used, are critical to achieve accountability and avoid fatigue. In the case of the VPA, the EC (EU 2007a, EU 2007b, FERN 2008) states that the design and implementation of the VPA must include stakeholder involvement or a consultation process. In the case of the Indonesian VPA, minimum standards for participatory stakeholder consultation were defined (Box 15).

MSPs are a means of capturing a broader range of voices and involving relevant people in certain choices; however, such choices must lead to a decision by somebody with the necessary authority. In some cases, it might even be advisable not to open up a process to a wider group unless the process will be well organised by a multidisciplinary team and with transparent documentation. MSPs take time and designing an MSP requires a realistic approach to the amount of time needed for dialogue. Stakeholder

\section{Box 15. Agreed principles for the VPA}

- Stakeholders should be involved in every step of the process for a VPA.

- The VPA should also recognise FPIC principles.

- The negotiation process between the government of Indonesia and the EU must be transparent with clear information and adequate communication between all stakeholders.

- The VPA must be binding for both parties and implemented with clear activities and targets.

- The VPA should include activities to review the participatory aspects of legislation in a partner country, to identify the shortcomings and injustices of the system, and to consider the basic principles of responsible forest management.

- The mandate of negotiation should ensure that the procedure within the partner country is transparent and includes civil society participation.

- The importance of ensuring that there is a role for civil society in verification and monitoring must be recognised. 
consultation can easily delay crucial developments and raise expectations, although the trade-offs of omitting such processes are lower credibility, ownership and oversight.

\subsubsection{Consultation processes for REDD+}

Consultation processes for REDD+ have, understandably, involved a wider range of sectors than the VPA consultations. Nevertheless, crucial sectors remain unengaged. Some perceive the civil society arena surrounding REDD+ as less cohesive. Therefore, adopting a common position and clear ownership over the direction to be taken has been problematic.

A number of cross-sectoral institutional mechanisms have developed around REDD+, all with the objective of coordinating and involving a range of stakeholders. The Indonesia Forest Climate Alliance (IFCA) multi-stakeholder forum, established in July 2007 in preparation for COP 13, involved an analysis of Indonesia's methodological and policy readiness and analysed how REDD+ could be implemented as a carbon emission reduction mechanism (IFCA 2008). The IFCA process was coordinated by the World Bank and supported by the governments of Australia, Germany and the UK. National and international experts gathered to prepare papers examining the necessary supply chain in producing carbon credits in REDD+ projects.

Subsequent consultation processes took place in relation to the R-PP (Readiness Preparation Proposal) to the FCPF in 2009 and the UN-REDD programme. However, both these processes and IFCA were criticised for failing to adhere to due process for civil society consultation and transparency (Daviet et al. 2009, DTE 2009b, CSF 2010, FERN 2010, Norad 2010) and there were accusations that international commitments had been made without adequate information or consultation.

In 2009, Kemitraan (the multi-stakeholder Partnership for Governance Reform) started to raise awareness at the provincial level of the importance of consultation and of widening stakeholder involvement (Dermawan et al. 2011: 3). The REDD+ Strategy, led by national rather than international institutions in the case of the FCPF, has been developed through a range of consultation processes, with drafts available on the Internet with the specific aim of building national consensus (Kompas 2010b, redd-monitor.org 2010b). More recently, UKP4 has launched a web-based portal that enables civil society to post photographic evidence of land that is classified as forested but that does not have standing forests, and other irregularities.

The process included regional consultations in Java, Lombok, Aceh, Central Sulawesi, Kalimantan and Papua, as well as national and international consultations. Civil society has since been involved through representation on each REDD+ Task Force working group and the drafting team. In addition, 3 working groups of the REDD+ Task Force involved coordination amongst ministries and the participation of representatives from the private sector, research centres, funding bodies, NGOs and the Adat community. However, the Ministry of Agriculture and the Ministry of Energy and Mineral Resources, which are not represented on the REDD+ Task Force, have been less involved, creating a risk of conflicting mandates with these crucial landbased sectors.

The key issues raised during the consultation processes (see, for example, Norad 2010: 38, Cronin and Santoso 2011:2) include concern over the narrow definition of key terms such as the consultation process; concern over how to avoid a narrow focus on carbon accounting that leads to neglect of poverty reduction; the lack of adequate consultation with stakeholders, particularly indigenous people; the context of flawed governance; and the need to guarantee social and environmental safeguards.

In the case of REDD+, as in the case of the legality standards, it is likely that the process of setting national standards will be 'vulnerable' to NGO campaigns, which to some extent will help determine the demands of the market. This is because REDD+ is currently evolving in the form of bilateral (such as the LoI) or multilateral (such as the REDD+ Partnership, FCPF and UN-REDD) agreements with their associated safeguards. In addition, NGOs have played a significant role in shaping REDD+ internationally (and in some cases nationally) and are involved in implementation. However, some 
perceive the civil society arena surrounding REDD+ to be more problematic and less cohesive than that surrounding illegal logging, for the following reasons.

- The nature of the debate: The technical details of REDD+ design create the risk of excluding some elements of civil society.

- The scope of the debate and the nature of the NGOs involved: In Indonesia, the Civil Society Forum for Climate Justice (CSF), which has been dominant in many REDD+ discussions, deals with climate-related issues generally and does not specialise in forestry. However, in October 2010, 11 Indonesian NGOs established a common platform on REDD+ (see Greenpeace 2010), thus creating a more specific platform for such engagement. ${ }^{21}$

- Differences amongst organisations involved: NGOs involved in the FLEGT-VPA process claim that their success was to have developed a common position through an intense dialogue process; this common position enabled a stronger voice. This kind of process has been less attainable in relation to REDD+ because organisations' attitudes to the mechanism differ greatly. NGOs in the forestry sector are traditionally divided between development and environmental agendas (see, for example, redd-monitor.org 2010a); other divisions exist between the positions of the groups involved in advocacy based on their REDD+ pilots and the more radical environmental groups that reject the concept of carbon offsets (e.g. Walhi). Finding a common position and ownership over the issues has been difficult: 'some see it [REDD+] as an opportunity, some see it as a threat and some see it as a commodity' (interview with a representative of a forest NGO 2011).

- The controversial nature of the issue: Issues relating to the forestry sector tend to be

21 The platform is composed of the following organisations: Walhi (Indonesian Forum for Environment), HuMa (Perkumpulan Untuk Pembaharuan Hukum Berbasis Masyarakat dan Ekologis), BIC (Bank Information Center), Sawit Watch, KpSHK (Konsorsium pendukung Sistim Hutan Kerakyatan), Forest Watch Indonesia, CSF (Civil Society Forum for Climate Justice), ICEL (Indonesia Center for Environmental Law), AMAN (Aliansi Masyarakat Adat Nusantara; Indigenous Peoples Alliance of the Archipelago), JKPP (Jaringan Kerja Pemetaan Partisipatif; Participatory Mapping Network), SP (Solidaritas Perempuan; Women's Solidarity for Human Rights) and Greenpeace. polarising and heated, and many forest-related NGOs have neither the experience nor the will to engage with policymakers constructively.

- The issue of sovereignty: The important issue of sovereignty has further complicated the NGO response, and may be a factor in some NGOs' reluctance to engage on higher issues of the future of the economy. Recent Greenpeace reports created some controversy in relation to the sovereignty issue (see, for example, Jurnal Nasional 2010).

The development of the SVLK was greatly enhanced by a process that considered lessons from voluntary timber certification initiatives. However, although the Bali Road Map emphasises that REDD+ pilots in Indonesia should be used to demonstrate how national REDD+ programmes could be implemented at the local level (Madeira et al. 2010), no systematic attempt has been made to draw on these demonstration activities, or other early REDD+ pilot projects, to inform policy. This is a lost opportunity for learning and for avoiding duplication of efforts, because current voluntary carbon market initiatives have made significant progress in terms of developing standards and rigorous third-party validation and verification processes. ${ }^{22}$

The experience from the FLEGT process demonstrates that MSPs can serve to capture a broader range of voices and involve affected communities and individuals in making informed choices. Ultimately, however, such choices must lead to a decision by the relevant authority. MSPs take time (FERN 2008), and designing one for REDD+ will require a realistic approach to the amount of time needed for dialogue. The current 'fast-track' discourse underpinning climate change actions may compromise the importance and value

22 New REDD+ methodologies and projects must be validated using accredited validators. In essence, validation is about ensuring that the planned emission reductions are based on a rigorous methodology (accounting for all relevant carbon pools) and that the project will harness co-benefits. A new methodology is subject to a dual validation under VCS guidelines. This process usually involves a commitment to revising baselines after 10 years. The subsequent verification serves to ascertain the actual reductions in emissions achieved during a predetermined period proposed by the REDD+ project proponent, for example, every 2 or 5 years after the start of the project. 
of a thorough MSP; the SVLK was adopted after more than 7 years of consultation and negotiation. Stakeholder consultation can easily delay crucial developments and raise expectations, although the trade-offs of omitting such processes are lower credibility, ownership and oversight. A key challenge will be to strike a balance between the time and costs of a REDD+ MSP and the need to be able to demonstrate tangible results. 


\section{Addressing underlying governance issues}

\subsection{The missing role of government: $A$ necessary part of independence?}

Under the SVLK, the government has little involvement in the functioning of the verification system. In REDD+, however, it is likely that the government will be more active in this respect. This raises the questions of the best allocation of functions and how checks and balances can be embedded to ensure independence. Independence is not necessarily related to the actors involved but rather to the structural arrangements and the presence of checks and balances.

An important question is the role of government in the design of the SVLK. One of the concerns of the EU-Indonesia FLEGT VPA Experts (2010) was the way the SVLK interacts with ongoing regulatory inspections of various government agencies and how the results of these inspections can affect the legality certificates if, for example, non-compliance is detected. The SVLK, as it has been designed, can be termed 'privatised regulation', whereby the MoF is not involved in accreditation or the auditing process and has no authority to sign off on the legal compliance of an operator. This means that the government has little involvement in the functioning of the verification system other than its role in developing the standards and, in some cases, financing audits. ${ }^{23}$

This has the advantage of increasing the system's credibility in the eyes of some (the ministry is the regulator so its absence from verification enhances independence); in many senses, this is what civil society called for (see Walhi 2006). Cashore and Stone (2010: 17) suggest that this limited involvement of government is one way of bypassing 'potential corruption or uncertainties about implementation'. However, other observers feel this has gone too far and have called for a secretariat

23 For the purposes of the VPA, the MoF will have additional roles; these include a Licence Information Unit within the MoF to deal with queries regarding the validity of licences/the legality of timber, and additional monitoring by the JIC, which is a GoI/ EU composite body. within the MoF to play an oversight role or for some other part of government to be officially involved.

For example, questions have been raised about the degree to which KAN can deal with an administrative problem when it is the role of the regulatory authority to deal with a misdemeanour. Regulation P.02/VI-BPPHH/2010 includes an annex on submitting objections but does not include details on how KAN is to deal with these objections. It appears that the only action that KAN can take is to revoke the accreditation of an auditing company that it deems has failed to follow due process in responding to the complaint (interview with JPIK member 2011).

The current design for REDD+ in Indonesia, however, gives the government a significant role because the mechanism will involve national accounting. The role of the government could potentially range from a minimal role in terms of involvement in administration (as in the case of the SVLK) to a role where it uses more fully its capacity and existing systems. The challenge is to maintain the SVLK's level of 'independence' whilst increasing the involvement (and thus chances for reform) of state institutions and processes. A possible consequent discussion could consider whether this 'outsourcing model' constitutes an example of capacity substitution, thus directing efforts and resources away from strengthening existing structures, or whether it represents an efficient approach, given the inevitable capacity constraints within state institutions. This is a pertinent discussion in the context of decisions surrounding the nature of the REDD+ agency in Indonesia. In terms of credibility, however, the questions concern the best allocation and devolution of functions and how checks and balances can be embedded to ensure independence.

Brown et al. (2008), in exploring the concept of independence in the context of legality verification, suggest that independence is not solely a characteristic of the organisation or the individual competences of each actor involved (true 
independence is rare); rather, it is related more to the system and the steps taken to ensure independence. Using individual auditors that are independent of all interest groups

may be inadequate in contexts where political decision-making is highly politicized or commercial pressures present an overwhelming constraint. No matter how well designed the verification system is, if the polity is 'neo-patrimonial' in its functioning (that is, rewards are allocated largely through political patronage...) then it is unlikely that verification agents will be able to act independently (Brown and Tucker 2006: 3).

These authors suggest that 'more stable democratic accountability could well come from democratic arrangements to deliver independence through a forum of public scrutiny' and the development of other checks and balances that work within the existing system of governance and public accountability (Brown and Tucker 2006: 5). Examples of the use of this 'architectural' arrangement for ensuring independence include Ecuador's (former) outsourced monitoring system, where the monitoring function was shared amongst a number of agencies: NGOs, government and industry; Costa Rica, where a mixture of state, state-private and independent agents are used in the control and verification of the forestry sector; peninsular Malaysia, where a series of checks and balances between various public sector and external audits is used; and Honduras, where an external independent forest monitor acts under the supervision of the Human Rights Commission (Brown et al. 2008).

The lesson for REDD+, therefore, is that it is necessary to recognise that different audiences may require different MRV mechanisms and that the objectives of each system must be clear.

\subsection{Tackling drivers head-on or side- stepping reform?}

For REDD+ to be effective, underlying governance issues (such as tenurial uncertainty, regulatory loopholes and lack of attention to due process) must be addressed. The SVLK, based on verification via third-party audit, may be useful as a temporary confidence-building exercise but will not necessarily result in more fundamental reforms of the forest administration and control system.

A key question for both REDD+ and measures to address illegal logging is whether they can address underlying failings in the system as a whole or whether they are in fact side-stepping more fundamental reforms which may be needed to address deforestation and degradation. Looking at impact is particularly important in the case of REDD+, as it will eventually be measured in terms of outcome. Under measures such as FLEGT-VPA, market incentives are linked to performance based on adherence to process rather than on impact on illegal logging. That is, benefits are provided as a reward for following procedures rather than for having a measurable impact on illegal logging. Rewarding direct outcomes in terms of impact on illegal logging would require rewarding performance based on indicators such as improved management and reduced illegal logging rates, most of which are beyond the scope of the SVLK. However, in practice, currently no system rewards carbon emission reduction performance at the scale of REDD+; rather, the emphasis has been on process. There has always been a danger that, with the emphasis on adherence to internationally agreed standards, such initiatives become overly concerned with process (e.g. this is a particular problem with ISO process standards) and less concerned with outcome.

The FLEGT-VPA process in Indonesia has contributed to the ongoing process of governance reform in the forestry sector. It has achieved this through attention to MSPs, civil society capacity building, development of transparency mechanisms and increasing levels of oversight in the sector. There is evidence of increased capacity for engagement, and constructive relationships have been built amongst civil society, local/national government and the private sector as a result of the MSPs; these processes have been beneficial in terms of creating ownership. In addition, the fact that the SVLK should be able to trace the origin of every tree represents a huge step for transparency and has the potential to reduce corruption at many levels. However, it is too soon to assess the effect of these positive features on actual illegal logging trends or, indeed, to determine whether it is correct to assume that attention to these features will result in impacts. The 2-year 
target before the EU Timber Regulation becomes operational in 2013 sets a demanding schedule for Indonesia to fulfil the requirements.

Much analysis suggests that for REDD+ to work, underlying governance failings must be addressed. Therefore, before examining illegal logging measures for related lessons for REDD+, it is important to assess whether illegal logging measures can address these governance failings. The key question is whether these processes help to leverage wider sector reform - what Gale (1988, as discussed in Cashore and Stone 2010) has termed the 'ratcheting up' of governance standards - or whether they merely help to maintain the status quo and the 'ratcheting down' of forest governance standards. The recent reduction of PT Rimba Jaya's carbon concession in Central Kalimantan in favour of oil palm indicates that such broader reforms may be slower in coming than is generally expected (Fogarty 2011).

This involves assessing whether the design of the FLEGT-VPA in Indonesia was set within the framework of a vision and a clear trajectory for relevant governance reform in the forestry sector and how related measures support such reform. The FLEGT-VPA measures appear to be based on the assumption that the private sector and civil society are the primary drivers of change; as such, the private sector is managed by 'getting the incentives rights' and civil society via close attention to transparency, accessibility of data and mechanisms for public oversight. One overall concern about the narrow focus of the FLEGT-VPA on private sector performance is its assumption that industry is the main driver of illegality (Brown 2011). However, as our discussion shows, private sector operators form just one kind of player in a more complex game of forest governance, which also involves state players. Many observers agree that legality verification on its own cannot address the plethora of governance challenges facing the forestry sector and it should not be expected to do so: 'A powerful export industry is not necessarily an adequate foundation on which to build more broad-based governance reform', particularly as it could be argued that governance reforms depend as much on domestic industry performance as on the export market (Brown 2011: 1).
The significant challenges that remain cannot necessarily be resolved through the SVLK. These include corruption, unclear land use plans and demarcation, unclear rights to the forest and more powerful (financially and politically) drivers of deforestation and degradation such as demand for palm oil and mineral resources. The SVLK cannot cover many of the aspects of forestry sector administration relevant to illegal logging (e.g. licensing and resource allocation, control and revenue collection). For example, one key area of concern is the high level of logging occurring as a result of conversion of forestland to other purposes. The timber harvesting permit (Ijin Pemanfaatan Kayu; IPK), which is required for clearing forested areas, allows companies to clear-cut areas for conversion to other land uses, but many companies use the permits only to obtain the timber, and do not ultimately use the land (Sandker et al. 2007).

The limitations of the SVLK standards in relation to the fundamental issues of gazettement and FPIC, as discussed above, are another case in point. In theory, the SVLK for FLEGT is required to address the allocation of resources, tenure and user rights (Proforest 2011). Through the public complaints mechanism it will be possible to bring the gazettement issue to the attention of authorities in importer countries. The land tenure issues can also be discussed by the Joint Implementation Committee, which oversees the implementation of VPA. The market-based forces in the form of VPA can potentially contribute to pushing for the muchneeded land tenure reforms in Indonesia. However, the actual steps toward effective resolution of the gazettement problem remains Indonesia's sovereign decision. This gazettement question can potentially weaken the legality standard. NGOs have expressed fears that an overriding emphasis on verifying the credibility of documentation does not encourage land tenure and natural resource reforms (Walhi 2006). The risk that the status quo will be maintained casts doubts on the validity of claims that FLEGT can help address issues of land tenure (Merckx 2011) in the context of Indonesia.

Experience from Cambodia suggests that the design of any forest oversight mechanism needs to be based on an understanding of the political complexities of 
the sector (Luttrell and Brown 2006: 28). Failure to fully understand the intricacies can ultimately lead to validation of the status quo. Therefore, a key question is whether a narrow audit function is appropriate given the complexity of the Indonesian context. The Cambodia experience suggests that instituting an independent third-party auditor with a narrow remit is not appropriate in a context of severe governance problems in the sector, partly because the situation can place the auditor in a compromising position (Luttrell and Brown 2006), and partly because some level of government buy-in is required for reforms to take place. Although it is relatively easy to set up an audit system to address a specific problem, a larger challenge - particularly for REDD+ - is how to improve the wider governance system. Dermawan et al. (2011) suggest that addressing issues in process design, such as transparency, is not sufficient to improve forestry sector governance; rather, more fundamental reforms such as clarity and consistency of land use, transparency of concession allocation, accountability in forest finance, and integration of realistic land right policies must be enabled. The limitations of the SVLK standard in this regard should be taken into account.

Looking at wider impacts involves going beyond an audit system with operator compliance. Under the VPA, this function will be performed by a systemwide audit and 'third-party monitoring' (in the form of 'periodic evaluation'); this function is perhaps the most crucial element in achieving international credibility. However, details of this periodic evaluation, including the role and responsibility of the JIC upon receiving the audit report, have not yet been specified. Ideally, such a system-wide evaluation should judge the clarity of the role of each actor, the methods used by the independent monitors and the government approval mechanism, as well as compliance. Protocols for this evaluation need to be clearly set out, including precision on certain key issues such as whether or not the evaluators should be accompanied during their 'field assessments'.

It can be argued that the SVLK, with its requirements for a $\mathrm{CoC}$ subject to third-party audit, has made a significant contribution toward addressing fundamental failings in the control o timber trade in Indonesia (see Wells et al. 2007 for a related discussion). On its own, however, it is not sufficient to affect fundamental reforms or to promote good forest governance (Cashore and Stone 2010: 18). There are some possible avenues for the FLEGT-VPA process to support system-wide reform. For example, it is likely that pressure from the civil society groups involved in JPIK will ensure the wider debate on impact continues.

The focus on process that characterises the FLEGT-VPA could be viewed as problematic in other respects also. The civil society independent monitoring system, as formalised in the SVLK, and the complaint system into which it feeds, currently monitors only the auditing process, and not the overall forest administration and control system. Civil society independent monitors will be under pressure to note procedural flaws in order to make complaints. Many groups involved in the civil society monitoring will also be interested in monitoring the role of the supervisory government agencies but it not clear whether this will be possible under this function.

Another danger is that the VPA will limit itself to niche operators supplying the EU market (which makes up about $15 \%$ of Indonesia's timber products export market), which could reduce its impact. The government's impressive commitment to license all export operators under the same system partially addresses this risk, although, in the short term, this appears to be more an unrealistic aspiration than a binding commitment. 


\section{Cross-cutting issues for FLEGT and REDD+ in tackling illegal logging in Indonesia}

There have been 2 broad approaches to addressing illegal logging in Indonesia: law enforcement and trade-based measures such as FLEGT-VPA. Experiences with both approaches provide lessons for REDD+ in Indonesia in terms of process and impact. Process lessons are drawn from how the mechanism was designed. Outcome lessons consider the effects such measures have had, or may have, in reducing deforestation and forest degradation, and in addressing their underlying governancerelated causes. Attention to process is important for enhancing credibility and for engendering national ownership, both key features of a robust system. Several pertinent aspects of the design of the SVLK mirror the concerns that are currently being raised in discussions on the design of REDD+ institutions and systems. The SVLK was initially developed in a context where the existing forest control system was perceived as lacking the independence and transparency needed for international credibility and where, at the same time, domestic concern for independence and transparency was lacking. Therefore, the need to enhance national ownership by addressing sovereignty concerns was paramount. Much of the design of the SVLK focused on the issue of how to address these deficits.

Impacts can be divided into impacts on illegal logging itself and impacts on the governance issues that underpin the main drivers of illegal logging. Law enforcement efforts have had some immediate impacts on illegal logging, with reported decreases in smuggling and significant closure of sawmills in some areas (Suara Karya Online 2006). However, the sustainability and significance of this impact are questionable, particularly as they tend to net primarily small-scale operators and the courts have not yet proven capable of dealing with many of the larger-scale perpetrators.

Experience with trade-based approaches such as FLEGT-VPA and certification provides significant lessons for REDD+ in terms of process, but it is too early to assess the longer-term impact. It appears that trade-based approaches are likely to bring positive reforms in the operations of the private sector (previously a driver of illegal logging) but less likely to bring about more fundamental reforms to governance. Given the heavy focus on the role of governance reforms in the success of REDD+ implementation, this discussion is relevant for understanding which approaches can best enable success.

We identify a number of cross-cutting areas where pertinent lessons for REDD+ can be drawn from attempts to tackle illegal logging. These are:

1. broad contextual governance challenges;

2. law enforcement;

3. specific technical MRV-related challenges;

4. securing compliance with social and environmental safeguards;

5. access to information; and

6. institutional reforms and capacity.

7. engendering ownership

\subsection{Broad governance challenges}

The FLEGT-VPA process in Indonesia has increased the amount of attention paid to multi-stakeholder involvement, civil society capacity building and development of transparency mechanisms. The fact that the SVLK should be able to trace the origin of every tree has the potential to reduce corruption at many levels. Despite this significant contribution, the SVLK may not necessarily result in more fundamental reforms of the forest sector, reducing tenure uncertainty, closing regulatory loopholes, bringing attention to due process, and reducing the high levels of logging occurring as a result of conversion of forestland to other purposes.

It appears that these fundamental governance issues must be addressed if REDD+ is to be effective. REDD+ may present an opportunity to consolidate governance reforms in the context of Indonesia's extractive regime. In this sense, REDD+ has the potential to lead to broader governance reform than SVLK and VPA. 
A key challenge for both REDD+ and initiatives to control illegal logging is whether they can address underlying governance failings in the system as a whole or whether they in fact leave untouched more fundamental reforms that may be needed. A particular concern is that the current emphasis on verifying the credibility of documentation in FLEGT-VPA might encourage the status quo and thus fail to push for wider reforms. Central to this concern is the nature of the standards applied. In the process of developing legality standards, concerns were raised that they neglected gazettement requirements and shifted away from the standard of FPIC towards mere 'consultation' with local communities. These concerns remain in some quarters. For example, it is theoretically possible to get legality certification without final gazettement ever taking place. If an operator can prove that the gazettement did not occur due to neglect by the government (for example, that it paid as required but the government did not carry out its due responsibility), then the operator can get a legality certificate. Therefore, a key question is whether a narrow audit function is appropriate given the complexity of the Indonesian context, partly because the situation can place the auditor in a compromising position and partly because some level of government buy-in is required for reforms to take place. This same concern may affect REDD+, which will be similarly dependent on the credibility of validation and verification documents, and the independence of validation and verification processes. The limitations of the SVLK approach in this regard should be taken into account when designing the REDD+ process.

The current design of verification systems raises the question of whether MRV should primarily serve the purpose of international credibility or should aim to complement national reform agendas such as the improvement of the forest control system. The current design of the SVLK, which sits parallel to the existing mandatory system by introducing a third-party audit, is effective as a temporary confidence-building exercise, but it may not lead to more fundamental reforms. Hence, one lesson for REDD+ is that different objectives may require different MRV mechanisms and there is a need for clear identification of the key objective or audience. Developing one all-encompassing MRV system to serve subnational, national and international purposes will help to ensure efficiency, accountability and complementarity between countries and avoid duplicating - or worse, undermining existing national processes. The FLEGT-VPA experience suggests the benefit of adopting a phased approach with the initial objective of building up international credibility.

\subsection{Law enforcement}

Implementation relies on effective law enforcement. Law enforcement is a primary tool for eradicating those aspects of illegal logging that trade-related measures such as the VPA cannot address. Political commitment to law enforcement is currently high and some initiatives are underway: the OHL joint enforcement sweeps, proposed legislation on illegal logging, the use of the anti-judicial-mafia task force to investigate illegal logging and the new anti-corruption and anti-money laundering laws. However, enforcement measures taken against illegal logging have met with mixed success. For example, the OHL enforcement sweeps were criticised as merely responding to political pressure to deliver prosecutions rather than reflecting serious efforts to address the root causes of illegal logging. Recurring problems include the tendency to 'net the small fish' rather than the big players, a lack of transparency over the methods and standards used, a lack of accountability over the disbursement of revenue from the auctioning of illegal timber seized and the undermining of local government authorities.

The role of the courts has also been challenged, as critics point to systemic weaknesses in the judicial system, protracted delays in securing prosecutions and a tendency for law enforcers to approach forest crime as an administrative offence. Whilst some statistics suggest that court performance is improving, doubts persist as to whether there is genuine improvement in law enforcement, with the suggestion that fewer cases are being brought to the courts. Exacerbating this issue are changes in the nature of illegal logging: perpetrators are increasingly able to legitimise their actions by obtaining legal permits albeit through illegal means. As long as illegal logging is viewed as an administrative rather than a criminal offence, law enforcers will focus on 
the existence of documentation rather than on the process by which such documentation was obtained. Article 50(2) of the Forestry Law (No. 41/1999), which defines destructive logging as a forest crime, does in theory allow law enforcement agencies to look beyond legality in combating forest crime and hence increase the chances of catching bigger players. However, this legal provision is rarely used, and a root cause of the failure to prosecute illegal logging offences lies in the ambiguities in forestry laws.

New enforcement tools such as the anti-corruption and anti-money laundering laws may offer more effective ways to catch larger players that have not been directly linked to timber extraction activities on the ground. The emphasis has therefore shifted from 'follow the logs' to 'follow the money'. The hope is that this new legislation will make it easier to catch the strategists and financiers behind illegal logging. Related to this, the KPK has been able to start to recover financial losses incurred by the state. The anti-money laundering law is significant because it brings illegal logging under the purview of the banking sector and anti-corruption authorities. CIFOR recently developed Customer Due Diligence and Enhanced Due Diligence Guidelines for the Bank of Indonesia to assist in these efforts.

Nevertheless, the lack of information flow and cooperation between the Ministry of Forestry and the various law enforcement agencies continues to hamper the successful enforcement of laws to combat illegal logging. To date, the number of prosecutions has been limited, mainly because of the secrecy of banking operations and the police's reluctance to use the new legislation.

\subsection{Challenges in monitoring, reporting and verification}

Problems with data credibility exist in both the illegal logging and the REDD+ arenas. These problems include the existence of unclear and multiple definitions, contested data and standards, and limitations in measurement capacity and data quality. These weaknesses have resulted in multiple conflicting estimates of critical factors such as the volume of illegal timber produced and the amount by which carbon emissions might be reduced.
Data inconsistencies and incomparability present problems for setting standards, setting reference levels and monitoring. The challenges encountered during the process of setting the SVLK standard (e.g. determining which laws should be included in an assessment of legality) are likely to be even greater when establishing forest definitions and other standards for REDD+ because the debate spans many more issues than the legality debate.

Resolving contestations over definitions and data estimates requires an agreement on whose knowledge counts and who has the legal and legitimate authority to decide which data are correct. One of the main concerns in the legality standard-setting process was the lack of clarity over authority distributed amongst levels and sectors of government. That ambiguity made it possible for the same batch of timber to be judged both legal and illegal depending on which interpretation or governing authority was prioritised. Similarly, the decision-making architecture emerging in the REDD+ debate in Indonesia is increasingly complex. Clear authority over MRV for REDD+ remains an element of this complexity. The LoI that Indonesia and Norway signed in May 2010 includes a condition to establish an independent REDD+ agency, MRV system and financing instrument. The fundamental questions of institutional authority and which institutions will have overall responsibility for decision-making on MRV, as well as on other aspects of operationalising REDD+, remain unresolved.

No decisions have been made on how emission reductions due to REDD+ will be verified in a compliance market. Nevertheless, it is clear that establishing an MRV system with both national and subnational acceptance and international credibility will be a key requirement for REDD+. Despite the concerns of the Group of 77 developing countries within UNFCCC negotiations that a requirement for international approval of a national MRV system would violate national sovereignty, it is likely that independent verification will be a requirement for trading forest carbon credits on any market - whether compliance or voluntary. To create and maintain credibility, Indonesia will have to ensure clear standards, independent verification and transparency. 
Many of the concerns clouding the design of the SVLK and the Indonesian VPA revolved around this issue of how to guarantee independence. Thus, the experience of the FLEGT-VPA provides a number of lessons on how to create independence in a system for REDD+ monitoring and verification. The SVLK relies on 'operator-based' licensing, similar to the approach used by the voluntary certification process. Points of debate include the low levels of internal control in the system, the fact that Indonesia has more than one export licensing authority and the problems of finding impartial auditors. The principle of separation of mandates for accreditation, standard-setting, monitoring and verification is fundamental for the independence and credibility of the SVLK, and will be for REDD+ systems as well. Clear reporting, public consultation and disclosure provisions and mechanisms for corrective action can act to strengthen both mechanisms. Additional lessons for REDD+ include those on increasing the effectiveness of civil society monitoring, with a view to requirements for clarity of process, public access to information and guidelines for impartiality.

\subsection{Securing compliance with social and environmental safeguards}

The wider scope of MRV in a REDD+ agreement under the UNFCCC has not yet been determined. In particular, there has been no resolution over what types of social and economic safeguards should be included and whether the mechanism should include MRV of sustainable development policies and measures. In the meantime, the rules for MRV systems are evolving under bilateral agreements. Regardless of the final UNFCCC decision, it can be argued that MRV for credibility will also require attention to 'non-carbon' issues. Since COP 16 in Cancún, Mexico, in 2010, the government of Indonesia, with the MoF taking the lead, has begun to define its own standards for safeguards.

A related issue is the avoidance of unintended impacts - a key area of concern for both REDD+ and measures to control illegal logging. Unintended impacts include leakage (the displacement of carbon emissions), the movement of legal or illegal deforestation to other locations, the shifting of international markets to less stringent buyers, negative impacts on the livelihoods of the poor and the exclusion of small-scale operators due to the high technical and financial barriers of entry.

\subsection{Access to information}

Transparency is an important principle in REDD+ and a fundamental design feature to ensure the success of measures for tackling illegal logging. Conversely, lack of access to information and absence of transparency of decision-making are key weaknesses that may foster the development of corrupt practices. For example, the lack of transparency over procedures and protocols and lack of clarity over the use of funds from timber auctions held after the OHL law enforcement sweeps led to accusations of unlawful appropriation of confiscated timber and misappropriation of funds by OHL personnel. The design of the SVLK and the VPA depend heavily on the assumption of accessibility and transparency of information and on functioning systems to provide this information. A key feature of the SVLK is the formal recognition of the civil society 'independent monitoring' function in the Indonesian TLAS, or SVLK, that allows civil society to submit objections when irregularities are found in the accreditation, assessment or licensing processes. In practice, however, civil society monitors will encounter difficulties in accessing the information they require. Therefore, although the data availability requirements agreed to in the VPA represent an important opportunity for reform, their stringency may prove a weakness of the system, as it will make fulfilling the requirements difficult.

Some recent positive changes in access to information are evident in the forestry sector, including the 2011 regulation on public information services $(\mathrm{MoF}$ Regulation No. P.7/Menhut-II/2011) and the online tracking system for transport permits, forest royalty fees and reforestation fees. However, the information listed in the regulation on public information is only aggregated information and is insufficient for independent monitoring purposes. For example, early analysis of the 2011 Presidential Instruction regarding the moratorium on new licences suggests that the data used to produce the maps of primary forest and peatland cannot be independently verified with publicly available data. 
A crucial factor for the effective operation of the REDD+ MRV institution is a mechanism to ensure that it can get access to all necessary data on time. The challenge for the MRV mechanism in REDD+ is 3-fold, with the need for (1) improvements in data quality; (2) a mechanism for data sharing and transparency both within and amongst institutions; and (3) publicly accessible information in a form that is independently verifiable and understandable for the layperson.

\subsection{Institutional reforms and capacity}

Lack of capacity is a contextual factor that needs to be taken into account in the design of any new initiative. The design of REDD+ should be cognisant of weaknesses, rather than assuming that well-functioning systems are in place. The narrow timeframes set for introducing measures to combat illegal logging as well as REDD+ present huge capacity-building challenges, both across sectors and across levels of government, the private sector and civil society. For example, significant weak points in the implementation of illegal logging measures are enforcement and sanctioning mechanisms.

Under the SVLK, the government has limited involvement in the functioning of the system. The $\mathrm{MoF}$ is not involved in accreditation or auditing and it has no authority to sign off on an operator's legal compliance. The government sets up the systems and standards, and then withdraws by outsourcing the MRV to credible third parties. This can have the advantage of increasing the system's perceived credibility. However, the question does arise of whether the outsourcing model of the SVLK constitutes an example of capacity substitution, directing efforts and resources away from strengthening existing structures, or whether the model actually represents an example of capacity reinforcement for state institutions.

It is likely that the government will play a larger role in the MRV of REDD+ than it currently does in the SVLK. This is deemed necessary to ensure greater attention to aspects such as permanence and leakage, and will also help build accountability and ownership within the forest administration system. The challenge is to maintain the level of independence achieved by the SVLK whilst also increasing the involvement (and thus chances for reform) of state institutions and processes. This leads to questions about the appropriate allocation and devolution of functions and how to guarantee checks and balances to ensure independence. Other analysis has shown that independence is not necessarily related to the actors involved but rather to the architecture and the presence of checks and balances.

REDD+, similarly to many illegal logging measures, is a centrally designed process that requires implementation and monitoring at the local level. However, for REDD+, the critical MRV challenge will be establishing nested jurisdictional accounting systems to avoid the risk of 'hot air' crediting, and to clarify who has responsibility for liabilities (namely, shortfalls in delivering credits). This raises the question of how to set appropriate incentives and thus help to build ownership, accountability and capacity in local government. Achieving this will require solutions for key questions in terms of how to accommodate jurisdictional differences between districts and provinces within a national system.

The FLEGT-VPA process in Indonesia also provides valuable lessons on using consultation processes, on involving civil society and the private sector in the design, and on civil society monitoring. Multistakeholder processes have emerged as important conditions for the success of both REDD+ and VPA-driven legality systems and as an important part of building buy-in into these processes. Involving multiple stakeholders enhances legitimacy, effectiveness and public scrutiny. However, opening up a process to multiple stakeholders inevitably leads to broadening of the remit and can slow down the process and raise expectations. In addition, it is important to ensure that such processes do not undermine more accountable forms of representation by taking the place of democratic decision-making forums. This concern arose in the early stages of the process to define legality standards: do the stakeholders being consulted hold the right to decide which laws are counted in the legality standard? That question was addressed by engaging an institution with more legitimacy to facilitate the process and formalise the protocols. Clearly defining roles and precisely communicating expected 
results and outputs, including how the results of the consultations will be used, are crucial for ensuring accountability and avoiding fatigue.

REDD+ and illegal logging measures differ significantly in their institutional architectures. Whereas illegal logging measures tend to be focused on the forestry sector, the REDD+ process spans multiple sectors and institutions. Therefore, consultation processes on REDD+ have involved a wider range of sectors than the FLEGT-VPA consultations. Nevertheless, crucial sectors - notably agriculture and mining - remain unengaged. Civil society groups engaged in REDD+ are less cohesive, which has made adopting a common position problematic. To some extent, this reflects divisions between development and environmental advocacy NGOs and may also be a factor in the relatively recent emergence of REDD+ as a policy issue.

One element of effective coordination is to ensure there is learning across scales. However, learning from demonstration activities or other early REDD+ pilot projects in Indonesia has not taken place in a systematic manner. This is a lost opportunity for learning and for avoiding duplication of efforts; for example, the development of the SVLK was greatly enhanced by a process that considered lessons from voluntary timber certification initiatives.

\subsection{Engendering ownership}

The early assumption that REDD+ would develop under an international agreement has not yet been realised. In the absence of this agreement and of significant private sector investment, much of the start-up finance is currently being provided through bilateral or multilateral relationships. In a context of increasing proliferation and fragmentation of climate finance, donors must align with each other and with national processes to avoid undermining or duplicating such initiatives.

Securing the support of business was a crucial element in reaching agreement on the VPA. For REDD+, this challenge is even more acute: whereas some elements of the private sector are the prime movers for innovation, those elements involved in alternative land uses such as oil palm, pulp and paper and mining currently constitute a massive barrier to
REDD+. For the VPA, demonstrating that there are clear benefits to compliance, as well as adopting of a step-wise approach to standard-setting, advanced its credibility in the private sector. These lessons are relevant to REDD+ in terms of how to engage the private sector.

One of the challenges for REDD+ is how to meet international demands whilst maintaining national ownership over the process. Given the fundamental importance of building and maintaining credibility, one option is to concentrate on meeting the minimum standards needed for international acceptance. However, a key element blocking the progress of the REDD+ debate in Indonesia is the widely held perception that the mechanism will undermine sovereignty and the interests of the national economy. Similar forms of resistance arose early in the VPA design debate, and the process stalled partly because of the need to meet international standards. Examining how this was overcome is illuminating, as it indicates the importance of paying attention to local ownership of the process, as well as the importance of demand-side measures - currently missing for REDD+. Demand has been an important part of the solution for the VPA: the signing of the EU Timber Regulation in 2010 significantly facilitated the VPA's progress, engendering crucial support amongst those who might have otherwise blocked it. Above all, the VPA experience demonstrates the value of an approach that works from both the supply and the demand ends. In the absence of a strong demand mechanism, as is the case with REDD+, perhaps more attention should be given to building and strengthening a national and public constituency as a possible lever to push for REDD+-related reforms.

Comparing REDD+ with illegal logging measures such as the FLEGT-VPA is instructive, but has its limitations. These 2 policy initiatives have had different time spans. Attention to illegal logging has been pursuing solutions for a more than a decade, whereas REDD+ has been developing over only 3-4 years. With its relatively longer time span, the FLEGT-VPA has been able to give greater attention to consultative processes, address conflicts and build ownership of the process. This has, in turn, enabled the development of a VPA design and process that are specific to Indonesia, thus resolving some of 
the concerns related to sovereignty and lack of ownership - an inevitable aspect of internationally driven processes. A clear lesson from the SVLK is that it is inadvisable to look for short cuts in the process. REDD+ is subject to much greater pressure, dominated by the discourse on 'fast-tracking' and the urgency of IPCC reports to avoid the risk of passing a climate change tipping point. Urgency in the discourse threatens to prevent REDD+ from being able to give close attention to key process issues. In this respect, it may be wise to reconsider the degree to which REDD+ processes that are implemented over a short time period can have fundamental governance impacts. 


\section{Key lessons learned}

This section outlines some of the key lessons for the ongoing design of REDD+ as identified in this working paper.

\section{Adopt an approach that harmonises common} REDD+ and SVLK MRV requirements. One such common requirement is the generation of accurate, complete and up-to-date data. Another is MRV capacity building, such as supporting data-sharing protocols within and across agencies, establishing linkages between databases used for the SVLK and REDD+ (e.g. inventories, management plans, harvest data) and compiling and sharing data on land use and land cover change, tenure, forest stock, type and location.

\section{Develop mechanisms for exchange of data and} transparency both within and between institutions and ensure information is publicly accessible, understandable and independently verifiable. This information should include:

- monitoring, land use and concession activity data to enable independent verification of the operations to which a given forest area has been subject and the implications for carbon stock balance;

- accrual and distribution of net revenues from REDD+;

- documentation demonstrating compliance with FPIC processes and socio-economic and environmental standards;

- verification and validation reports, audit reports, claims, records on any breaches of policy and practice identified, corrective decisions on verification results and actions taken; and

- guidelines and protocols for monitoring by civil society.

Enhance independence in the design of REDD+ MRV by ensuring the separation of mandates for accreditation, standard-setting, monitoring and verification. Acknowledge that independence is not necessarily related to the nature of the actors (i.e. ISO-accredited auditors or civil society); rather, it can be achieved by ensuring that checks and balances are embedded in the system architecture and that functions are allocated with clear and legal mandates.

Develop the role of civil society monitors and public oversight mechanisms to strengthen the credibility of REDD+ processes. Effective civil society monitoring needs clarity of process, public access to information and clear guidelines on how to guarantee impartiality. Whether the same civil society groups that are undergoing training to monitor timber audits could also monitor REDD+ processes should be explored, but it is possible that additional skill sets will be required.

\section{Ensure clarity of procedure for independent REDD+ validation and verification systems} including:

- public reporting, public consultation and public disclosure provisions;

- mechanisms for corrective decisions on verification results and action where breaches are identified;

- mechanisms for addressing non-compliance;

- mechanisms to report to the government on verification findings; and

- redress mechanisms and methods for dealing with non-compliance and attempts to undermine the process.

\section{Match the design of REDD+ systems and} institutions to a realistic and rigorous ex ante assessment of capacity to help avoid the process being stalled. Wherever possible, promote REDD+ systems and processes that strengthen existing systems rather than undermining, distorting or duplicating them.

\section{Clarify the roles and mandates of local and central} government, as well as ways to accommodate jurisdictional differences within a national REDD+ system, whether through decentralisation of functions or devolution of authority. The role of local government is currently unclear in the operation both 
of enforcement measures such as the OHL and of the SVLK and REDD+; the result is a lack of ownership at that level. Clarifying rights and responsibilities for MRV at national and local levels will help to direct incentives towards the right parties.

\section{Acknowledge that different objectives and audiences (e.g. international credibility, domestic reform) have different MRV needs. Given the} fundamental importance of building and maintaining credibility, one option is to focus primarily on the minimum standards needed for international acceptance. However, this approach may fail to foster national ownership and thus undermine longer-term sustainability of the process.

\section{Ensure that MSPs play a central role in REDD+ design and implementation. The SVLK process has shown that MSPs take time. Encourage them to be nationally owned rather than donor-driven. Clearly defined roles and precise communication on expected results and outputs, including how the results of the consultations will be used, are crucial for ensuring accountability and managing participants' expectations.}

Given the government of Indonesia's commitment to both fund- and market-based REDD+, it is necessary to ensure buy-in from the private sector by guaranteeing and demonstrating the benefits of engaging in REDD+. This requires attending to the demand side. It also requires mitigating risk for private sector operators, for example through stepwise approaches to standard-setting and compliance, the targeted use of public funds to leverage finance from the private sector and the exploration of publicprivate partnerships.

\section{Pay particular attention to aspects of law} enforcement such as:

- defining a clearer role for enforcement agencies/ penalties/sanctions and increased interaction between these agencies and the MoF;

- broadening the understanding of illegal logging by emphasising use of Article 50(2) of Law No. 41/1999 when dealing with forest crime to encourage law enforcement to look beyond administrative aspects and investigate violations related to the permit itself, corruption and negative impacts of legal concession activities; and

- extending law enforcement's approach to illegal logging to use related instruments such as the anti-corruption and anti-money laundering laws, to reach the financial backers and corrupt officials who turn a blind eye to illegal activities in the forest. 
Abrahamsen, J. 2010 Linkages between REDD and illegal logging. Paper to Chatham House, $16^{\text {th }}$ Illegal Logging Meeting, London, UK, 24-25 June 2010. http://www.illegal-logging.info/ uploads/ Abrahamsen250610.pdf [31 May 2011].

Aid for Development Effectiveness Secretariat (A4DES) 2010 The Jakarta commitment overview [Presentation]. A4DES, Jakarta, Indonesia. http:// www.scribd.com/doc/35384004/A4DE-TheJakarta-Commitment [9 September 2010].

AgroIndonesia 2007a Jatah hutan untuk rakyat. AgroIndonesia 3(131): 1.

AgroIndonesia 2007b HTR, ajak rakyat sebagai pemain hutan. AgroIndonesia, Special edition, Info HTR, p. a.

AgroIndonesia 2007c Magnet baru bernama HTR. AgroIndonesia, Special edition, Info HTR, p. d.

AgroIndonesia 2010 Ekspor Kehutanan Kini Mengacu SVLK. http://agroindonesia.co.id/2010/10/11/ ekspor-kehutanan-kini-mengacu-svlk/

[15 May 2011].

Analisa 2011 FKMA minta stop illegal logging. 17 March. http://koleksi-berita.blogspot.com/ 2011/03/fkma-minta-stop-illegal-logging.html

http://www.etfrn.org/etfrn/newsletter/news52/ Chapters/2.2-Andrianto-Obidzinski-Komarudin. pdf [31 May 2011].

Angelsen, A. with Brockhaus, M., Kanninen, M., Sills, E., Sunderlin, W.D. and Wertz-Kanounnikoff, S. (eds.) 2009 Realising REDD+: national strategy and policy options. CIFOR, Bogor, Indonesia.

Antara 2010 Greenomics criticizes govt data on illegal logging decline. 16 July. http://www.antaranews. com/en/news/1279270171/greenomics-criticizesgovt-data-on-illegal-logging-decline [9 September 2011].

Bank of Indonesia 2010 Table V.8. Value of export by group of commodities: Indonesian financial statistics. November 2010. p. 129 http://www. bi.go.id/web/en/Statistik/Statistik+Ekonom i+dan+Keuangan+Indonesia/Versi+HTML/ Sektor+Eksternal/Sektor+Eksternal.htm [31 May 2011].

Barr, C. 2001 Banking on sustainability: structural adjustment and forestry reform in post-Suharto
Indonesia. WWF Macroeconomics Programme Office, Washington, DC, and CIFOR, Bogor, Indonesia.

Barr, C., Dermawan, A., Purnomo, H. and Komarudin, H. 2010 Financial governance and Indonesia's reforestation fund during the Soeharto and postSoeharto periods, 1989-2009: a political economic analysis of lessons for REDD+. CIFOR Occasional Paper No. 52. CIFOR, Bogor, Indonesia.

Barr, C., Resosudarmo I.A.P., Dermawan, A. and McCarthy, J. 2006 Decentralization of forest administration in Indonesia: implications for forest sustainability, economic development and community livelihoods. CIFOR, Bogor, Indonesia.

Boer, R. 2010 Indonesia MRV report. Internal report to CIFOR. CIFOR, Bogor, Indonesia.

Brack, D., Marijnissen, C. and Ozinga, S. 2002 Controlling imports of illegal timber: options for Europe. Forests and European Union Resources Network (FERN), Brussels, Belgium, and The Royal Institute of International Affairs (RIIA), London.

Bradley, A. 2010 Communities and carbon establishing a community forestry-REDD project in Cambodia. Pact, Washington, DC.

Brown, D. 2011 A comparative analysis of REDD+ and FLEGT design and implementation. Presentation summary for seminar 'From global intentions to local improvements', The Hague, Netherlands, 19 April 2011. http://www.tropenbos.nl/images/ Tropenbos/news/ expert_meeting_knowledge_ network_19042011/09_summary\%20brown.pdf [31 May 2011].

Brown, D. and Tucker, J. 2006 On independence in verification work. VERIFOR Briefing Paper 2, Overseas Development Institute, London. http:// www.verifor.org/resources/briefing-papers/2independence.pdf [31 May 2011].

Brown, D., Schreckenberg, K., Bird, N., Cerutti, P., Gatto, F.D., Diaw, C., Fomete, T., Luttrell, C., Navarro, G., Oberndorf, R. et al. 2008. Legal timber verification and governance in the forest sector. Overseas Development Institute, London.

Brown, D.W. 1999 Addicted to rent: corporate and spatial distribution of forest resources in 
Indonesia; implication for forest sustainability and government policy. Report No. PFM/ EC/99/06. Indonesia-UK Tropical Forest Management Programme, Jakarta, Indonesia. www.perhimpunan-karsa.org/download/Addicted. doc [9 September 2011].

Brown, D.W. and Stolle, F. 2009 Bridging the information gap: combating illegal logging in Indonesia. World Resources Institute, Washington, DC.

Brown, J. and Peskett, L. 2011 Climate finance in Indonesia: lessons for the future of public finance for climate change mitigation. Working Paper 11. Overseas Development Institute, London.

Brown, T.H., Simangunsong, B.C.H., Sukadri, D., Brown, D.W., Sumarta, S., Dermawan, A. and Rufi'ie. 2005. Restructuring and revitalization of Indonesia's wood-based industry: synthesis of three major studies. Ministry of Forestry, CIFOR and Department for International DevelopmentMultistakeholder Forestry Programme (DFIDMFP), Jakarta, Indonesia.

Burgess, R., Hansen, M., Olken, B., Potapov, P. and Sieber, S. 2011 The political economy of deforestation in the tropics. http://econ-www.mit. edu/files/6632 [31 May 2011].

Butler, R. 2008 Papua signs REDD carbon deal to generate income from rainforest protection. mongabay.com. 14 May. http://news.mongabay. com/2008/0514-papua.html [31 May 2011].

Butler, R. 2011 Borneo province selected for Indonesia's first pilot under REDD program. http://replantingtherainforests.org/site/index.php/ Rainforest-Solutions/borneo-province-selected-forindonesias-first-pilot-under-redd-program.html [8 June 2011].

Cashore, B. and Stone, M. 2010 Can legality verification rescue global forest governance? Assessing the interacting effects of economic mechanisms on forest policy and governance with lessons learnt from Southeast Asia. Research Seminar. http://www.illegal-logging.info/uploads/ IUFRO CashoreStone.pdf [31 May 2011].

Cashore, B. and Galloway, G. (convening lead authors), Cubbage, F., Humphreys, D., Katila, P., Levin, K., Maryudi, A., McDermott, C., McGinley, K., Kengen, S., et al. 2010 Ability of institutions to address new challenges. In: Mery, G., Katila, P., Galloway, G., Alfaro, R.I., Kanninen, M., Lobovikov, M. and Varjo, J. (eds.) Forests and society: responding to global drivers of change,
441-486. IUFRO World Series 25. International Union of Forest Research Organizations, Tampere, Finland.

Casson, A. and Obidzinski, K. 2002 From New Order to regional autonomy: shifting dynamics of illegal logging in Kalimantan, Indonesia. World Development 30(12): 2133-2151.

Center for International Forestry Research (CIFOR) 2011 International cooperation to help reduce illegal logging through integrated law enforcement approach. Final Report. Unpublished.

Center for International Forestry Research (CIFOR) and North Carolina State University (NCSU). 2010 proyek percontohan [Sample projects]. CIFOR, Bogor, Indonesia. http://www.reddindonesia.org/index.php?option=com_content\&vie $\mathrm{w}=$ article\&id=205\&Itemid=57 [15 May 2011] .

Center for International Trade in Forest Products (CINTRAFOR) 2002 Discrepancies in forest products trade statistics. Fact sheet 55. University of Washington, WA, USA.

Climate Society Forum (CSF) 2010 Pernyataan sikap terhadap konsultasi publik REDDI-Readiness RPP-FCPF Kementrian Kehutanan RI. http:// www.csoforum.net/media-release/19-pernyataansikap/246-pernyataan-sikap-atas-kp-r-pp-fcpfindonesia.html [18 May 2011].

Colchester, M., Jiwan, N., Andiko, Sirait, M., Firdaus, A.Y., Surambo, A. and Pane, H. 2006 Promised land: palm oil and land acquisition in Indonesia implications for local communities and indigenous peoples. Forest Peoples Programme, Perkumpulan Sawit Watch, Bogor, Indonesia.

Colfer, C., Ganga, R.D. and Capistrano, D. (eds.) 2008 Lessons from forest decentralization: Money, justice and the quest for good governance in Asia-Pacific. Earthscan, London.

Contreras-Hermosilla, A. and Fay, A. 2005 Strengthening forest management in Indonesia through land tenure reform: Issues and framework action. Forest Trends, Washington, DC.

Cronin, T. and Santoso, L. 2010 REDD+ politics in the media: a case study from Indonesia. CIFOR Working Paper 49. CIFOR, Bogor, Indonesia.

Daviet, F., Davis, C., Goers, L. and Nakhooda, S. 2009 Ready or not? A review of the World Bank Forest Carbon Partnership R-Plans and the UN REDD Joint Program Documents. WRI Working Paper. World Resources Institute, Washington DC. 
Dermawan, A., Petkova, E., Sinaga, E., Muhajir, M. and Indriatmoko, Y. 2011 Risks of corruption in REDD+ in Indonesia: abbreviated report. Draft. CIFOR, Bogor, Indonesia.

Detik News 2005 Operasi Hutan Lestari, 25 tersangka illegal logging diringkus. 18 March.

Dewan Nasional Perubahan Iklim (DNPI) 2009 Fact sheet - Indonesia greenhouse gas emission cost curve. http://forestclimatecenter.org/ files/2009-08-27\%20Fact $\% 20$ Sheet $\% 20$ -\%20Indonesia\%20Greenhouse\%20Gas\%20 Emission\%20Cost\%20Curve\%20by\%20 Indonesia\%20National\%20Council\%20on $\% 20$ Climate\%20Change.pdf [31 May 2011].

Dewan Nasional Perubahan Iklim (DNPI) 2010 Rekomendasi langkah tindak: pengembangan measurable, reportable and verifiable (MRV). Jakarta.

Down to Earth (DTE) 2009a Lebih banyak hutan akan dikorbankan untuk pulp (More forest to be sacrificed for pulp). 80-81 (June). http://www. downtoearth-indonesia.org/id/story/lebih-banyakhutan-akan-dikorbankan-untuk-pulp [9 September 2011].

Down to Earth (DTE) 2009b REDD+ concerns deepen. 82 (Sept). http://dte.gn.apc.org/82acl.htm [9 September 2011].

Elson, D. 2011 Cost-benefit analysis of a shift to a low carbon economy in the land use sector in Indonesia. Low Carbon Development Unit of the UK Embassy, Jakarta, Indonesia. http:// ukinindonesia.fco.gov.uk/resources/en/pdf/2011/ presentation-d-braithwaite-energy

[9 September 2011].

Environmental Investigation Agency (EIA) and Telapak 2002 Illegal logging and the international trade in illegally sourced timber: how CITES can help and why it should. EIA and Telapak, London and Jakarta, Indonesia. http://www.eia-international. org/files/reports38-1.pdf [31 May 2011].

Environmental Investigation Agency (EIA) and Telapak 2005 The last frontier: illegal logging in Papua and China's massive timber theft. EIA and Telapak, London and Jakarta, Indonesia.

Environmental Investigation Agency (EIA) and Telapak. 2010 Rogue traders: the murky business of Merbau timber smuggling in Indonesia. Telapak, Bogor, Indonesia.

European Commission (EC) 2003 Forest Law Enforcement, Governance, and Trade
(FLEGT): proposal for an EU action plan. EC, Brussels, Belgium.

European Union (EU) 2007a FLEGT briefing notes: Voluntary Partnership Agreements. Briefing Note No. 06. EU, Brussels, Belgium.

European Union (EU) 2007b Guidelines for independent monitoring. Briefing Note No. 7. http://www.euflegt.efi.int/files/attachments/euflegt/ efi_briefing_note_07_eng_221010_b.pdf [31 May 2011].

EU-Indonesia FLEGT VPA Experts 2010 Technical report, VPA experts meeting. Jakarta, Indonesia, 15 January 2010. http://www.dephut.go.id/files/ Technical_Report_Expert_Meeting_150110.pdf [31 May 2011].

Food and Agriculture Organization of the UN (FAO) 2007 State of the world's forests. FAO, Rome. http://www.fao.org/docrep/009/a0773e/a0773e00. htm [31 May 2011].

Fogarty, D. 2011. Special report: How Indonesia crippled its own climate change. Reuters, 16 August. http://www.reuters.com/ article/2011/08/16/us-indonesia-carbonidUSTRE77F0IK20110816 [20 September 2011.

Forest Stewardship Council (FSC) 2010 Lembaga Ekolabel Indonesia. www.fsc.org/1134.html. [ 7 June 2011].

Forest Watch Indonesia (FWI) 2003 Dampak kebijakan larangan ekspor kayu bulat: pada periode 19851997 terhadap sektor kehutanan Indonesia. Intip hutan, April 2003. http://fwi.or.id/publikasi/intip_ hutan/Larangan.pdf [31 May 2011].

Forest Watch Indonesia (FWI) 2009 Potret kondisi hutan Indonesia dan kinerja pelaku di sektor kehutanan, In Portret Keadaan Hutan Indonesia Periode 2000-2009 Bogor, Indonesia.

Forest Watch Indonesia (FWI) and Global Forest Watch (GFW) 2002 The state of the forest: Indonesia. FWI, Bogor, Indonesia, and GFW, Washington, DC.

Forests and European Union Resources Network (FERN) 2008 Consultation requirements under FLEGT. Loggingoff Briefing Note 1 (March). http://www.fern.org/sites/fern.org/files/2008.06_ Consultation\%20Requirements\%20under\%20 FLEGT_EN.pdf [9 September 2011].

Forests and European Union Resources Network (FERN) 2010 Lessons learned from FLEGT for REDD: why ignoring key lessons from initiatives to control illegal logging will lead REDD to 
a dead-end. FERN, Gloucestershire, UK/ Brussels, Belgium.

Foundation for International Environmental Law and Development (FIELD) 2011 REDD-plus briefing paper. The fourteenth session of the Ad Hoc Working Group on Long-term Cooperative Action under the Convention (AWG-LCA14) (first part) and the sixteenth session of the Ad Hoc Working Group on Further Commitments for Annex I Parties under the Kyoto Protocol (AWG-KP16) (first part). Bangkok, Thailand, 5-8 April 2011. http://www.field.org.uk/files/ fieldreddbriefingpaper032011_en_0.pdf [9 September 2011].

Gale, F. 1998 The tropical timber trade regime. Macmillan Press, Basingstoke, UK. http:// www.bokklubben.no/SamboWeb/produkt. do?produktId=809733 [31 May 2011].

Garuda Indonesia, PT (Persero) 2010 Garuda Indonesia to join IATA offset program [Press release]. http:// www.garuda-indonesia.com/news/2010/02/02/ garuda-indonesia-to-join-iata-offset-program [31 May 2011].

Gellert, P.K. 2003 Renegotiating a timber commodity chain: the politics of the Indonesia-Japan plywood link. Sociological Forum 18: 53-84.

Gellert, P.K. 2010 Extractive regimes: toward a better understanding of Indonesian development. Rural Sociology 75: 28-57.

Gibbs, H.K., Brown, S., Niles, J.O. and Foley J.A. 2007 Monitoring and estimating tropical forest carbon stocks: making REDD a reality. Environmental Research Letters 2: $045023 \mathrm{http} / /$ unfccc.int/files/methods_science/redd/application/ pdf/env_res_letters_forest_carbon.pdf [31 May 2011].

Government of Indonesia (GoI) 2010 National REDD+ strategy (Revised 23 September 2010). National Development Planning Agency, Jakarta, Indonesia. http://www.un.or.id/sites/default/files/ COMPLETEStranas1RevisedEng\%20final\%20 version.pdf [31 May 2011].

Government of Indonesia (GoI) 2011 Strategi Nasional REDD+ (Final Draft, 17 August 2011). National Development Planning Agency, Jakarta, Indonesia. http://ukp.go.id/informasi-publik/doc_details/12draft-final-strategi-nasional-redd

[13 September 2011].

Government of Indonesia (GoI) and EU 2011a FLEGT Voluntary Partnership Agreement between the Republic of Indonesia and the European Union.
Briefing Note. May 2011.http://www.efi.int/files/ attachments/euflegt/briefing_note_indonesia_ en_.pdf [31 May 2011].

Government of Indonesia (GoI) and EU 2011b Draft Voluntary Partnership Agreement between the Republic of Indonesia and the European Union on Forest Law Enforcement, Governance and Trade in Timber Products into the European Union, Final as agreed by $3^{\text {rd }}$ Senior Officials Meeting. 15 April 2011.

Government of Indonesia (GoI) and EU 2011c VPA Annex V. 2011. Indonesian Timber Legality Assurance System. Annex V to the Draft Voluntary Partnership Agreement between the Republic of Indonesia and the European Union on Forest Law Enforcement, Governance and Trade in Timber Products into the European Union, Final as agreed by $3^{\text {rd }}$ Senior Officials Meeting. 15 April 2011.

Government of Indonesia (GoI) and EU 2011d VPA Annex VII. 2011. Terms of Reference for Independent Market Monitoring. Annex VII to the Draft Voluntary Partnership Agreement between the Republic of Indonesia and the European Union on Forest Law Enforcement, Governance and Trade in Timber Products into the European Union, Final as agreed by $3^{\text {rd }}$ Senior Officials Meeting. 15 April 2011.

Government of Indonesia (GoI) and Government of Norway 2010 Letter of Intent between the Government of the Kingdom of Norway and the Government of the Republic of Indonesia on 'Cooperation on Reducing Greenhouse Gas Emissions from Deforestation and Forest Degradation'. http://www.norway.or.id/ PageFiles/404362/Letter_of_Intent_Norway_ Indonesia_26_May_2010.pdf [31 May 2011].

Grainger, A. 2008 Difficulties in tracking the long-term global trend in tropical forest area. PNAS 105: 818-823.

Greenpeace 2005 Partners in crime: the UK timber trade, Chinese sweatshops and Malaysian robber barons in Papua New Guinea's rainforests. http:// www.greenpeace.org.uk/MultimediaFiles/Live/ FullReport/7251.pdf [31 May 2011].

Greenpeace 2010 Indonesia civil society organizations' common platform on saving Indonesia's forest to protect the global climate. http://www.greenpeace. org/seasia/id/PageFiles/110812/cso-commonplatform.pdf [31 May 2011].

Guizol, P. and Aruan, A. 2004 Impact of incentives on the development of forest plantation resources 
in Indonesia, with emphasis on industrial timber plantations in the outer islands. In: Enters, T., Durst, P. (eds.) What does it take? The role of incentives in forest plantation development in Asia and the Pacific. Food and Agriculture Organization of the UN, Bangkok, Thailand.

Hafild, E. 2010 'PGI-REDD+' governance assessment: a preliminary framework. Paper presented at the Second Expert Workshop on Monitoring Governance for REDD+. Organised by UN-REDD and Chatham House. FAO Headquarters, Rome, 18-19 November 2010. http://www.illegal-logging.info/uploads/ PGIREDDbyEmmyHafild18Nov2010.pdf [31 May 2011].

Hartoyo, D. 2011 Panduan audit investigatif korupsi di bidang kehutanan. CIFOR, Bogor, Indonesia. http://www.cifor.cgiar.org/publications/pdf_files/ Books/BHartoyo 1101.pdf [31 May 2011].

Human Rights Watch 2009 'Wild money': the human rights consequences of illegal logging and corruption in Indonesia's forestry sector. Human Rights Watch, New York.

Indonesia Forest Climate Alliance (IFCA) 2008 Consolidation report: reducing emissions from deforestation and forest degradation in Indonesia. IFCA, Ministry of Forestry, Jakarta, Indonesia.

Indonesian Civil Society 2005 EU action plan on Forest Law Enforcement, Governance and Trade (FLEGT): Agreed principles from Indonesian civil society for a Voluntary Partnership Agreement.

Indonesian Forum for Environment (Walhi) 2006 Usaha sistematis 'penurunan kriteria' legalitas kayu meminggirkan aspek sosial: catatan kritis proses penyusunan kriteria dan standar 'wood legality'. Paper Note, 29 September 2006. http://rullysyumanda.blogspot.com/2007/06/usaha-sistematispenurunan-kriteria.html or http://groups.yahoo. com/group/rimbawan-interaktif/message/15579 [31 May 2011].

Intergovernmental Panel on Climate Change (IPCC) 2003 Intergovernmental Panel on Climate Change (IPCC) Good practice guidance for land use, landuse change and forestry. http://www.ipcc-nggip. iges.or.jp/public/gpglulucf/gpglulucf_files/0_ Task1_Cover/Cover_TOC.pdf [31 May 2011].

Intergovernmental Panel on Climate Change (IPCC) 2006 IPCC report on good practice guidance for land use, land-use change and forestry - chapter 2: basis for consistent representation of land areas. http://www.ipcc-nggip.iges.or.jp/public/gpglulucf/
gpglulucf_files/Chp2/Chp2_Land_Areas.pdf [31 May 2011].

Irawati, R. Melati, H. and Purnomo, H. 2009 Analysis of value chain governance: scenarios to develop small-scale furniture producers. Jurnal Manajemen Hutan Tropika 15: 96-101. http://jtip.journal.ipb. ac.id/index.php/jmht/article/view/3246

[9 September 2001].

Jakarta Globe 2010 With no new permits in Indonesia, Sinar Mas to enter Liberia. 3 September. http:// www.thejakartaglobe.com/naturalresources/withno-new-permits-in-indonesia-sinar-mas-to-enterliberia/394464 [31 May 2011].

Jakarta Globe 2011a Special report: how $\$ 115 b$ illegal logging probe was felled. 19 May. http:// www.thejakartaglobe.com/nvironment/specialreport-how-a-115b-illegal-logging-probe-wasfelled/441679 [31 May 2011].

Jakarta Globe 2011b A timeline of the Riau investigation. 19 May. http://www.thejakartaglobe. $\mathrm{com} /$ nvironment/a-timeline-of-the-riauinvestigation/441823 [31 May 2011].

Jakarta Post 2007 Aceh to implement logging moratorium. 13 March. http://www.illegal-logging. info/item_single.php?it_id=1974\&it=news [31 May 2011].

Jakarta Post 2008 Greenpeace hails Papua log export ban. 28 March. http://www.thejakartapost.com/ news/2008/03/28/greenpeace-hails-papua-logexport-ban.html [31 May 2011].

Jakarta Post 2009 Illegal logging continues in Aceh despite moratorium. 27 October. http://www. thejakartapost.com/news/2009/10/27/illegallogging-continues-aceh-despite-moratorium.html [31 May 2011].

Jakarta Post 2010a KPK warns ministry about problematic loopholes. 4 December. http://www. thejakartapost.com/news/2010/12/04/kpk-warnsministry-about-problematic-loopholes.html [31 May 2011].

Jakarta Post 2010b REDD forests have 'unclear' borders. 12 October. http://www.thejakartapost. $\mathrm{com} /$ news/2010/10/12/redd-forests-have$\%$ E2\%80\%98unclear\%E2\%80\%99-borders.html [9 September 2011].

Jasin, M. 2010 The use of anti corruption law in the forestry sector in Indonesia. Paper presented to the 14th International Anti-Corruption Conference (IACC) 2010. Bangkok, Thailand, 10-13

November 2010. www.14iacc.org [9 September 2011]. 
Joshi, L., Janudianto, van Noordwijk, M. and Pradhan, P. 2010 Investment in carbon stocks in the eastern buffer zone of Lamandau River Wildlife Reserve, Central Kalimantan province, Indonesia: a REDD+ feasibility study. World Agroforestry Centre (ICRAF), Bogor, Indonesia.

Jurgens, E. 2006 Learning lessons to promote certification and combat illegal logging in Indonesia: September 2003 to June 2006. CIFOR, Bogor, Indonesia.

Jurnal Nasional 2010 Greenpeace diminta tak campuri kebijakan Indonesia. 26 October.

Kahar, J. 2010 Kelompok kerja informasi geospasial perubahan iklim. Pertemuan teknis pembangunan infrastruktur data geospasial untuk penurunan emisi gas rumah kaca. Dewan Geomatika Indonesia, Bandung, Indonesia.

Klassen, A.W. 2010 Domestic demand: the black hole in Indonesia's forest policy. In: Witt, M. and van Dam, J. (eds.) Chainsaw milling: supplier to local markets, 15-22. Tropenbos International, Wageningen, Netherlands.

Kleden, E., Indradi, Y. and Chidley, L. 2009 Forests for the future: indigenous forest management in a changing world. Aliansi Masyarakat Adat Nusantara and Down to Earth, Jakarta. http://dte. gn.apc.org/GNSCON.htm [31 May 2011].

Kompas 2006 Kayu alam distop total mulai 2014 laju degradasi hutan 2,87 juta hektar per tahun. 28 April.

Kompas 2010a Perlindungan Hutan Terancam. 24 November. http://cetak.kompas.com/read/ 2010/11/24/03401267/perlindungan.hutan. terancam [9 September 2011].

Kompas 2010b Penyumbang emisi gas rumah kaca terbesar. 1 October. http://sains.kompas.com/read/ 2010/10/01/06311126/Penyumbang.Emisi.Gas. Rumah.Kaca.Terbesar [31 May 2011].

Kompas 2010c Ada kelemahan sistemik. 4 December. http://nasional.kompas.com/read/2010/12/04/ 0250502/Ada.Kelemahan.Sistemik [31 May 2011].

Kompas 2011 Investasi bisa di hutan rusak. 2 March. http://cetak.kompas.com/read/2011/03/02/ 02505849/investasi.bisa.di.hutan.rusak [31 May 2011].

Kusumaputra, R.A. 2011 DPR kritik LSM dukung moratorium hutan. [15 May 2011].

Lawson, S. and MacFaul, L. 2010 Illegal logging and related trade indicators of the global response. Chatham House, London. http://www. chathamhouse.org.uk/files/16980_0710crc_ illegallogging.pdf [31 May 2011].

Luttrell, C. 2007 Ownership in relation to the design of verification systems. VERIFOR Briefing Paper 5. Overseas Development Institute, London. http:// www.verifor.org/RESOURCES/briefing-papers/8multistakeholder.pdf [8 June 2011].

Luttrell, C. and Brown, D. 2006 The experience of independent forest monitoring in Cambodia. VERIFOR Country Case Study 4. Overseas Development Institute, London. http://www. verifor.org/RESOURCES/case-studies/cambodia. pdf [31 May 2011].

MacDicken, K. 2010 Wood or climate change forestry [opinion]. Jakarta Post, 29 October. http://www. thejakartapost.com/news/2010/10/29/wood-orclimate-change-forestry.html [15 May 2011].

Madeira, E.M., Sills, E., Brockhaus, M., Verchot, L. and Kanninen, M. 2010 What is a REDD+ pilot? A preliminary typology based on early actions in Indonesia. CIFOR Info Brief No. 20. CIFOR, Bogor, Indonesia.

Manurung, E.G.T., Simangunsong, B.C.H., Sukadri, D., Widyantoro, B., Justianto, A., Ramadhan, S., Sumardjani, L., Rochadi, D., Permadi, P., Priyono, B.M. and Supriyanto, B. 2007 Road map revitalisasi industri kehutanan Indonesia (Road map for revitalising Indonesia’s forestry industry). Ministry of Forestry, Jakarta, Indonesia.

Matthews, E. 2001 Understanding the FRA 2000. World Resources Institute, Forest Briefing No. 1. World Resources Institute, Washington, DC. sites.google.com/site/cursosliey/Matthews2001. pdfMauladi, V.Y. 2011 Moratorium konversi hutan; LoI RI-Norwegia harus dibatalkan. http:// www.suarakarya-online.com/news.html?id=272037 [15 May 2011].

McCarthy, J.F. 2010 The limits of legality: state, governance and resource control in Indonesia. In: Aspinall, E. and van Klinken, G. (eds.) The state and illegality in Indonesia, 89-106. KITLV Press, Leiden, Netherlands.

Merckx, V. 2011 FLEGT and REDD linkages. Paper to the 17th Illegal Logging Stakeholder Update. Chatham House, London, 28 January 2011. http://www.illegal-logging.info/uploads/ Merckx280111.pdf [31 May 2011].

Merger, E., Dutschke, M. and Verchot, L. 2011 Options for REDD+ voluntary certification to ensure net GHG benefits, poverty alleviation, sustainable management of forests and biodiversity 
conservation. Forests 2: 550-577. http://www. mdpi.com/1999-4907/2/2/550/pdf

[31 May 2011].

Ministry of Environment (MoE) 2010a Indonesia Second National Communication under the United Nations Framework on Climate Change Convention. MoE, Jakarta, Indonesia. http:// unfccc.int/files/national_reports/non-annex_i_ natcom/submitted_natcom/application/pdf/ indonesia_snc.pdf [31 May 2011].

Ministry of Environment (MoE) 2010b Pembentukan sistem inventarisasi gas rumah kaca nasional (SIGN) dan MRV nasional [Presentation]. MoE, Jakarta, Indonesia.

Ministry of Forestry (MoF) 2006 Rencana pembangunan jangka panjang kehutanan tahun 2006-2025. MoF, Jakarta, Indonesia.

Ministry of Forestry (MoF) 2004 Keputusan Menteri Kehutanan Nomor: SK. 101/Menhut-II/2004 tentang percepatan pembangunan hutan tanaman industry untuk pemenuhan bahan baku industri dan kertas. http://www.dephut.go.id/ INFORMASI/skep/skmenhut/101_04.htm.

Ministry of Forestry (MoF) 2007 Departemen Kehutanan alokasikan lahan hutan 5.4 juta hektar untuk usaha Hutan Tanaman Rakyat dengan dukungan Dana Reboisasi. Press release No. S.51/ II/PIK-1/2007, 22 February 2007.

Ministry of Forestry (MoF) 2008 Consolidation report: reducing emissions from deforestation and forest degradation in Indonesia. MoF, Jakarta, Indonesia. http://ebookbrowse.com/ifca-consolidation-reportredd-indonesia-pdf-d25948618 [31 May 2011].

Ministry of Forestry (MoF) 2009 Forestry statistics of Indonesia 2008. MoF, Jakarta, Indonesia http:// www.dephut.go.id/index.php?q=id/node/6122 [31 May 2011].

Ministry of Forestry (MoF) 2010a Strategi nasional REDD fase readiness 2009-2012 (versi Bahasa Indonesia dan Bahasa Inggris) 6 January. http:// www.forda-mof.org/uploads/2010/buku $\% 20$ redd\%20versi\%20Indonesia.pdf [31 May 2011].

Ministry of Forestry (MoF) 2010b Rapat persiapan tindak lanjut pelaksanaan LoI RI-Norwegia Phase Pertama (Minutes of meeting on the follow-up preparation of LoI between Indonesia and Norway, first phase). 11 June 2010. http:// www.dephut.go.id/files/LoI_Norwegia_ DirjenBPK_11062010_0.pdf [31 May 2011].

Ministry of Forestry (MoF) 2011 Pemerintah dan DPR RI Bahas RUU Pencegahan dan Pemberantasan
Pembalakan Liar (P3L). Press release number S.64/ PHM-1/2011, 7 February. http://www.dephut. go.id/index.php?q=id/node/7012

[22 March 2011].

Mott MacDonald 2010 Scoping study: developing countries monitoring and reporting on greenhouse gas emissions, policies and measures. http:// ec.europa.eu/clima/studies/g-gas/docs/country_ report_indonesia_2010_en.pdf [31 May 2011].

Multi-stakeholder Forestry Programme (MFP) 2006 Community-based forest management in Indonesia. What is it and how can its potential be harnessed for economic growth and poverty reduction? Draft Briefing Paper, MFP, DFID, Indonesia.

Mustaidah, A. 2010 DPR ajukan syarat moratorium hutan. 7 October. http://bataviase.co.id/ node/409175 [15 May 2011].

National Forestry Council (DKN) and UN-REDD Indonesia. No date. Policy recommendation: free, prior and informed consent (FPIC) instrument for indigenous communities and/or local communities who will be affected by REDD+ activities. http://un.or.id/sites/default/files/Policy\%20 Recommendation\%20FPIC_English_Final.pdf

Norwegian Agency for Development Cooperation (Norad) 2011 Real-time evaluation of Norway's international climate and forest initiative contributions to national REDD+ processes 2007-2010, country report: Indonesia. Norad, Oslo, Norway.

Nussbaum, R. 2010 How can FLEGT be used to achieve REDD objectives? Proforest, Oxford, UK. Presentation at the Chatham House and Rights and Resources Initiative, Third Dialogue on Forests, Governance and Climate Change. Chatham House, London, 22 January 2010. http://www.illegal-logging.info/uploads/ Nussbaum220110.pdf [31 May 2011].

Obidzinski, K. and Barr, C. 2003 The impact of decentralization policies on the forestry sector in the district of Berau, East Kalimantan. Case Study No. 9 on Decentralization and Forests in Indonesia. CIFOR, Bogor, Indonesia.

Obidzinski, K. and Chaudhury, M. 2009 Transition to timber plantation based forestry in Indonesia: towards a feasible new policy. International Forestry Review 11: 79-87.

Obidzinski, K. and Dermawan, A. 2010 Smallholder timber plantation development in Indonesia: 
what is preventing progress? International Forestry Review 12: 339-348.

Obidzinski, K., Andrianto, A. and Wijaya C. 2006a Timber smuggling in Indonesia: critical or overstated problem? Forest governance lessons from Kalimantan. CIFOR, Bogor, Indonesia. http:// www.cifor.cgiar.org/publications/pdf_files/Books/ BObidzinski0601.pdf [31 May 2011].

Obidzinski, K., Andrianto, A., Wijaya, C., Hernawan, D. and Belle, C.W. 2006b The cross border timber trade in Kalimantan: will stopping timber smugglers help solve the illegal logging problem in Indonesia? Governance Brief No. 17. CIFOR, Bogor, Indonesia.

Poffenberger, M., De Gryze, S. and Durschinger, L. 2010. Designing collaborative REDD projects: a case study from Oddar Meanchey Province, Cambodia. Community Forestry International, Antioch, CA, USA.

Proforest 2011 FLEGT-REDD+ linkages: working together effectively. Briefing Note 3. http://www. euflegt.efi.int/files/attachments/euflegt/flegt_redd_ bn_3_web.pdf [31 May 2011].

PT Pelangi Energi Abadi Citra Enviro (PEACE) 2007 Indonesia and climate change: current status and policies. PEACE, Jakarta, Indonesia.

Purnomo, A. 2011 Pemilihan kepala daerah dan deforestasi [opinion]. Koran Tempo, 8 March. http://www.mirror.unpad. ac.id/koran/korantempo/2011-03-08/ korantempo_2011-03-08_011.pdf [13 May 2011].

Purnomo, H. Achdiawan, R., Parlinah, N., Irawati, R.H. and Melati 2009 Value chain analysis of furniture: action research to improve power balance and enhance livelihoods of small-scale producers. Paper to the XIII World Forestry Congress. Buenos Aires, Argentina, 18-23 October 2009.

redd-monitor.org 2010a 'We want to change this threat to an opportunity': interview with Abdon Nababan and Mina Setra. 4 July. http://www.redd-monitor. org/2010/07/04/\%e2\%80\%9cwe-want-to-changethis-threat-to-an-opportunity\%e2\%80\%9dinterview/ [31 May 2011].

redd-monitor.org 2010b Comments invited on Indonesia's draft National REDD+ Strategy. 19 October. http://www.redd-monitor. org/2010/10/19/comments-invited-on-indonesiasdraft-national-redd-strategy/ [31 May 2011].

Rema, J.J. 2010 Komisi IV ragukan komitmen Norwegia. http://bataviase.co.id/node/366599 [15 May 2011].
Ribot, J.C., Agrawal, A. and Larson, A.M. 2006 Recentralizing while decentralizing: how national governments reappropriate forest resources. World Development 34: 1864-1886.

Sandker, M., Suwarno, A. and Campbell, B.M. 2007 Will forests remain in the face of oil palm expansion? Simulating change in Malinau, Indonesia. Ecology and Society 12(2): 37. [online] http://www.ecologyandsociety.org/vol12/iss2/ art37/ [31 May 2011].

Santoso, T., Chandra, R., Sinaga, A.C., Muhajir, M. and Mardiah, S. 2011 Panduan investigasi dan penuntutan dengan pendekatan hukum terpadu. CIFOR, Bogor, Indonesia. http://www.cifor.cgiar. org/publications/pdf_files/Books/BSinaga1 101.pdf [31 May 2011].

Saunders, J. and Reeve, R. 2010 Monitoring governance for implementation of REDD+. Background Paper 1 at Monitoring Governance Safeguards in REDD+ Expert Workshop. Chatham House, London, 24-25 May 2010.

Saunders, J., Eberling, J. and Nussbaum, R. 2008 Reduced emissions from deforestation and forest degradation: lessons from a forest governance perspective. Proforest, Oxford, UK. http://www. proforest.net/publication-objects/REDD\%20 and\%20Governance.pdf [9 September 2011].

Scheyvens, H. (ed.) 2010 Developing national REDDplus systems: progress challenges and ways forward: Indonesia and Viet Nam country studies. Institute for Global Environmental Strategies (IGES), Kanagawa, Japan. http://enviroscope.iges.or.jp/ modules/envirolib/view.php?docid=3051 [31 May 2011].

Schloenhardt, A. 2008 The illegal trade in timber and timber products in the Asia-Pacific region. Research and Public Policy Series No. 89. Australian Institute of Criminology, Canberra, Australia. http://www.aic.gov.au/documents/ B/D/4/\%7BBD4B2E50-33B4-47F1-815E901C0ACC7A43\%7Drpp89.pdf [31 May 2011].

Scotland, N., Fraser, A. and Jewell, N. 1999 Roundwood supply and demand in the forest sector in Indonesia. Indonesia-UK Tropical Forest Management Programme, Jakarta, Indonesia

Seneca Creek Associates and Wood Resources International 2004 Illegal logging and global wood markets: the competitive impacts on the US wood products industry (American Forest and Paper Association). http://www.illegal-logging.info/ uploads/afandpa.pdf [31 May 2011]. 
Setiono, B. and Hussein, Y. 2005 Fighting forest crime and promoting prudent banking for sustainable forest management. CIFOR, Bogor, Indonesia.

Sinar Harapan 2006 Dephut segera kembangkan HTI 3,6 juta hektar. 28 November.

Stark, T. and Cheung, S.P. 2006 Sharing the blame: global consumption and China's role in ancient forest destruction. Greenpeace International and Greenpeace China, Amsterdam, Netherlands.

Suara Karya Online 2006 Illegal logging: mabes polri tangkap 10 pengusaha kayu di kotim. http://www. suarakarya-online.com/news.html?id=134420 [8 June 2011].

Sugiharto 2007a DR kembali ke pangkuan Dephut. AgroIndonesia 3(135): 4.

Sugiharto 2007b Agenda baru memberantas kemiskinan. AgroIndonesia 3(131): 4.

Sugiharto 2007c 360,000 KK disiapkan bangun HTR. AgroIndonesia 3(135): 5.

Sugiharto 2007d Kesiapan rakyat dan pola yang tepat. AgroIndonesia 3(131): 5.

Sugiharto 2007e Izin HPH PT Itisixta diminta dicabut. Konawe Utara ingin HTR. AgroIndonesia 4 (175): 9.

Sugiharto $2007 \mathrm{f}$ Mimpi dengan dua juta hektar. AgroIndonesia, 30 January-5 February.

Sunderlin, W.D. and Resosudarmo, I.A.P. 1996 Rates and causes of deforestation in Indonesia: towards resolution of the ambiguities. CIFOR Occasional Paper 9. CIFOR, Bogor, Indonesia. http://www. cifor.cgiar.org/publications/pdf_files/OccPapers/ OP-09n.pdf [31 May 2011].

Tacconi, L. 2007 Verification and certification of forest products and illegal logging in Indonesia. In: Tacconi, L. (ed.) Illegal logging: law enforcement, livelihoods and the timber trade. Earthscan, London.

Tacconi, L. 2010 Linking policies to implement REDD+: decentralization, payments for environmental services and illegality. Paper to the International Conference-Forum on Emerging Economic Mechanisms: Implications for Forestrelated: Policies and Sector Governance. Rome, Italy, 5-7 October 2010. http://www.illegallogging.info/uploads/IUFROTacconi.pdf [31 May 2011].

Tacconi, L., Obidzinski, K. and Agung, F. 2004 Learning lessons to promote certification and control illegal logging in Indonesia. Report for the World Wide Fund for Nature and The
Nature Conservancy Alliance to promote forest certification and combat illegal logging in Indonesia. CIFOR, Bogor, Indonesia.

Telapak 2007 Development of the Indonesian Timber Legality Standard. http://www.illegal-logging.info/ uploads/indonesia_legality_standard.pdf [31 May 2011].

Telapak, Forest Watch Indonesia, Indonesian Working Group on Forest Finance (IWGFF), Yayasan Mitra Insani Riau, AMAN Kalimantan Barat, Perkumpulan Triton, Sorong, Pt. PPMA Jayapura, Walhi Kalimantan Timur, SKP Merauke, Yayasan Titian Pontianak, et al. 2009 Indonesia Civil Society's concern about Forestry Minister's Regulation No. 38/2009 concerning Standard and Guidelines on Performance Evaluation of Sustainable Forest Management and Timber Legality Verification for Licence Holders or Private Forests. Letter from Telapak et al. to the Director General of Forestry Production Development, Ministry of Forestry, dated 31 August 2009. http:// www.eia-international.org/files/news549-1.pdf [31 May 2011].

Tokede, M.J., Wiliam, D., Widodo, Gandhi, G., Imburi, C., Patriahadi, Marwa, J. and Yufuai, M.C. 2005 The impacts of special autonomy in Papua's forestry sector: empowering customary communities (Masyarakat Adat) in decentralized forestry development in Manokwari District. CIFOR, Bogor, Indonesia.

Unit Kerja Presiden bidang Pengawasan dan Pengendalian Pembangunan (UKP4) 2010 Indonesian-Norway Climate Change Partnership [PowerPoint presentation]. Jakarta, Indonesia.

United Nations Environment Programme (UNEP) 2007 The last stand of the orangutan. UNEP, GRID-Arendal, Norway. http://www.unep.org/ grasp/docs/2007Jan-LastStand-of-Orangutanreport.pdf [31 May 2011].

United Nations Framework Convention on Climate Change (UNFCCC) 2007 Decision 1/CP13; Bali Action Plan. Report of the Conference of the Parties on its Thirteenth Session, held in Bali, 3-15 December 2007. http://unfccc.int/resource/ docs/2007/cop13/eng/06a01.pdf\#page $=3$ [9 September 2011].

United Nations Office on Drugs and Crime (UNODC) 2010 The globalization of crime: a transnational organized crime threat assessment. UNODC, Vienna, Austria. http://www.unodc. 
org/documents/data-and-analysis/tocta/TOCTA_ Report_2010_low_res.pdf [31 May 2011].

United States Department of Agriculture Foreign Agricultural Service (USDA FAS) 2004 Indonesia: solid wood products annual 2004. Global Agricultural Information Network (GAIN) Report \#ID4020. USDA FAS, Jakarta, Indonesia. http:// www.fas.usda.gov/gainfiles/200407/ 146106727. pdf [31 May 2011].

van Assen, B. 2010 Certified jungles? ETFRN News 51 (Sept): 90-98.

van Heeswijk, L. 2010 Combating illegal logging: the EU-FLEGT Action Plan. A discourse analysis of the development of a legality-definition between and within the European Union and Indonesia. Master's thesis. Department of Environmental Sciences, Forest and Nature Conservation Policy Group, Wageningen University and Research Centre, Netherlands.

Verchot, L., Petkova, E., Obidzinski, K., Stibniati A., Yulyani E., Dermawan, A., Murdiyarso, D. and Salwa, A. 2010 Reducing forestry emissions in Indonesia. CIFOR, Bogor, Indonesia.

Wells, A., Nababan, A. and Poerba, B. 2007 Review of the UK-Indonesia memorandum of understanding on illegal logging. Overseas Development Institute, London, and Forest Watch Indonesia, Bogor, Indonesia. http://www.mfp.or.id/dev/2008/11/ impact-of-the-mou-illegal-logging/ [31 May 2011].

Wells, P. and Paoli, G. 2011 An analysis of Presidential Instruction No. 10, 2011. Moratorium on

\section{Laws and regulations}

\section{Indonesia}

Instruksi Presiden No. 4 tahun 2005 tentang Pemberantasan penebangan kayu secara ilegal di kawasan hutan dan peredarannya di seluruh wilayah Republik Indonesia (Presidential Instruction No. 4/2005 on Eradication of illegal logging in the forest area of the Republic of Indonesia), dated 18 March 2005. http://www. dephut.go.id/files/InPres4thn2005.pdfhttp://www. dephut.go.id/files/ InPres4thn2005.pdf.
Granting of New Licenses and Improvement of Natural Primary Forest and Peatland Governance. Daemeter Consulting, Bogor, Indonesia. http:// www.daemeter.org/wp-content/files/Daemeter Moratorium_Analysis_20110527_Final.pdf [9 September 2011].

Wibowo, H.D. 2011 Is CoC certification an effective tool to promote SFM or just a disguised form of NTBs? [Presentation] Sustainable Development Indonesia (SDI), Bogor, Indonesia. http://sdi.or.id/ publication/working/natural/dwcoc10mar2011.pdf [31 May 2011].

World Bank 2006 Sustaining economic growth, rural livelihoods, and economic benefits: strategic options for forest assistance in Indonesia. World Bank, Jakarta, Indonesia.

World Bank 2008 Climate change in Indonesia: low carbon development options study. Phase 1 Status Report. Paper presented at the National Consultation on 'A Regional Review of the Economic of Climate Change in South East Asia (PRECCS). Jakarta, Indonesia, 23-24 May.

WWF 2005 Failing the forests: Europe's illegal timber trade. WWF, Surrey, UK.

WWF 2008 Illegal wood for the European market: an analysis of the EU import and export of illegal wood and related products. WWF, Brussels, Belgium.

WWF/World Bank Alliance. 2005. WWF, World Bank would trim global deforestation 10 percent by 2010. 26 May. http://www.ens-newswire.com/ens/ may2005/2005-05-26-04.html [9 September 2011].

Instruksi Presiden No. 10 tahun 2011 tentang Penundaan pemberian izin baru dan penyempurnaan tata kelola hutan alam primer dan lahan gambut (Presidential Instruction No. 10/2011 on Postponement of issuance of new licenses and improving governance of primary natural forest and peatland), dated 20 May 2011. 
Peraturan Pemerintah No. 6 tahun 2007 tentang Tata Hutan dan Penyusunan Rencana Pengelolaan Hutan, serta Pemanfaatan Hutan (Government Regulation No. 6/2007 on Forest planning and forest management plans, and the utilization of forest and forest area), dated 8 January 2007.

Peraturan Pemerintah No. 3 tahun 2008 tentang Perubahan atas Peraturan Pemerintah No. 6 tahun 2007 tentang Tata Hutan dan Penyusunan Rencana Pengelolaan Hutan, serta Pemanfaatan Hutan. (Government Regulation No. 3/2008 on the Amendment to the Government Regulation No. 6/2007 on Forest planning and forest management plans, and the utilization of forest and forest area), dated 4 February 2008.

Peraturan Presiden No. 46 tahun 2008 tentang Dewan Nasional Perubahan Iklim (Presidential Regulation No. 46/2008 on National Climate Change Council), dated 4 July 2008. http://portal.djmbp. esdm.go.id/sijh/Perpres-46-2008.pdf.

Keputusan Menteri Kehutanan Nomor: SK.21/ Menhut-II/2009 tentang Penunjukkan Narasumber pada Kelompok Kerja Perubahan Iklim Lingkup Departemen Kehutanan (Ministerial Decree Number SK.21/MenhutII/2009), dated 27 January 2009.

Keputusan Menteri Kehutanan Nomor: SK.455/ Menhut-II/2008 tentang pembentukan Kelompok Kerja Perubahan Iklim di Lingkungan Departemen Kehutanan (Ministerial Decree Number SK.455/ Menhut-II/2008), as replaced by SK.13/MenhutII/2009 tentang Pembentukan Kelompok Kerja Perubahan Iklim Lingkup Departemen Kehutanan, dated 12 January 2009, as replaced by SK No. 64/ Menhut-II/2010 tentang Pembentukan Kelompok Kerja Perubahan Iklim Kementerian Kehutanan, dated 26 January 2010.

Keputusan Menteri Kehutanan Nomor: SK.70/ Menhut-II/2006 tentang pembentukan Panitia Pengarah Nasional Harmonisasi Standar Legalitas Kayu dan Pengembangan Kelembagaannya (Ministerial Decree Number SK.70/MenhutII/2006).

Peraturan Menteri Kehutanan (Permenhut) No. P.68/Menhut-II/2008 tentang Penyelenggaraan Demonstration Activities Pengurangan Emisi Karbon dari Deforestasi dan Degradasi Hutan (Ministry of Forestry Regulation No. P.68/ Menhut-II/2008 on the implementation of demonstration activities on reduction of emissions from deforestation and degradation), dated 11 December 2008.
Peraturan Menteri Kehutanan (Permenhut) No. P.30/ Menhut-II/2009 tentang Tata Cara Pengurangan Emisi dari Deforestasi dan Degradasi Hutan (Ministry of Forestry Regulation No. P.30/ Menhut-II/2009 on the Implementation Procedures of Reducing Emissions from Deforestation and Forest Degradation), dated 1 May 2009.

Peraturan Menteri Kehutanan (Permenhut) No. P.36/ Menhut-II/2009 tentang Tata Cara Perizinan Usaha Pemanfaatan Penyerapan dan/atau Penyimpanan Karbon pada Hutan Produksi dan Hutan Lindung (Ministry of Forestry Regulation No. P.36/Menhut-II/2009 on Procedures for Licensing of Commercials Utilisation of Carbon Sequestration and/or Storage in Production and Protected Forests), dated 22 May 2009.

Peraturan Menteri Kehutanan (Permenhut) No. P.38/ Menhut-II/2009 tentang Standar dan Pedoman Penilaian Kinerja Pengelolaan Hutan Produksi Lestari dan Verifikasi Legalitas Kayu pada Pemegang Izin atau pada Hutan Hak (Ministry of Forestry Regulation No. P.38/Menhut-II/2009 on Standards and Guidelines on Assessment of Performance of Sustainable Production Forest Management and Verification of Timber Legality for Licence Holders or in Private Forests), dated 12 June 2009.

Peraturan Menteri Kehutanan (Permenhut) No. P.50/ Menhut-II/2010 tentang Tata Cara Pemberian dan Perluasan Areal Kerja Izin Usaha Pemanfaatan Hasil Hutan Kayu (IUPHHK) dalam Hutan Alam, IUPHHK Restorasi Ekosistem, atau IUPHHK Hutan Tanaman Industri dalam Hutan Produksi (Ministry of Forestry Regulation No. P.50/ Menhut-II/2010 on Procedures on Issuing and Expanding IUPHHK Working Areas in Natural Forests, IUPHHK Ecosystem Restoration or IUPHHK-HTI for Production Forests), dated 31 December 2010.

Peraturan Menteri Kehutanan (Permenhut) No. P.7/ Menhut-II/2011 tentang Pelayanan Informasi Publik di Lingkungan Kementerian Kehutanan (Ministry of Forestry Regulation No. P.7/MenhutII/2011 on Public Information Service within the Ministry of Forestry), dated 2 February 2011.

Presidential Instruction, 2011. Instruction by the President of The Republic of Indonesia Number 10/2011. Suspension of Granting New Licenses and Improvement of Natural Primary Forest and Peatland Governance. [8 June 2011]. http://www.daemeter.org/wp-content/ 
files/INPRES-10_2011_EN.pdf (english), http://sipuu.setkab.go.id/PUUdoc/17176/ INPRES0102011.pdf (Indonesia).

Regulation P.02/VI-BPPHH/2010. (Director Peraturan Direktur Jenderal Bina Produksi Kehutanan, Nomor: P.02/VI-BPPHH/2010, Tentang Pedoman Pelaksanaan Penilaian Kinerja Pengelolaan Hutan Produksi Lestari dan Verifikasi Legalitas Kayu General of Forestry Production Development's Regulation Number: P.02/VI-BPPHH/2010 concerning Guidelines on Assessment of Sustainable Production Forest Management Performance and Verification of Timber Legality), dated 10 February 2010.

Regulation P.6/VI-Set/2009. Peraturan Direktur Jenderal Bina Produksi Kehutanan Nomor: P.6/VISet/2009 tentang Standard dan Pedoman Penilaian Kinerja Pengelolaan Hutan Produksi Lestari dan Verifikasi Legalitas Kayu (Director General of Forestry Production Development's Regulation Number: P.6/VI-Set/2009 concerning Standards and Guidelines on Assessment of Performance in Sustainable Production Forest Management and Timber Legality Verification), dated 15 June 2009.

Undang-Undang Republik Indonesia Nomor 41 Tahun 1999 tentang Kehutanan. Law Number 41 of 1999 on Forestry, dated 21 April 2011.

Undang-Undang Republik Indonesia Nomor 4 Tahun 2011 tentang Informasi Geospasial. Law Number 4 of 2011 on Geospatial Information, dated 21 April 2011.

\section{European Union}

Regulation No 995/2010 of the European Parliament and of the Council of 20 October 2010 laying down the obligations of operators who place timber and timber products on the market. http:// eur-lex.europa.eu/LexUriServ/LexUriServ.do?uri= OJ:L:2010:295:0023:01:EN:HTML. 


\title{
Annex
}

\section{Consultation meeting participants}

\author{
Consultation meeting \\ Lessons for REDD+ from the measures to control illegal logging in Indonesia \\ 19 May 2011, CIFOR \\ Bogor, Indonesia
}

\begin{tabular}{|c|c|}
\hline Institution & Name/position \\
\hline $\begin{array}{l}\text { Centre for Climate Risk and Opportunity } \\
\text { Management }\end{array}$ & $\begin{array}{l}\text { Doddy Juli Irawan } \\
\text { Research Assistant }\end{array}$ \\
\hline FFI Indonesia & $\begin{array}{l}\text { Darmawan Liswanto } \\
\text { Coordinator for FFI Indonesia }\end{array}$ \\
\hline FORDA - Puspijak & $\begin{array}{l}\text { Subarudi } \\
\text { Senior Researcher }\end{array}$ \\
\hline Ministry of Forestry & $\begin{array}{l}\text { Muladi } \\
\text { Staff - BUHA }\end{array}$ \\
\hline Multistakeholder Forestry Programme UK & $\begin{array}{l}\text { Andy Roby } \\
\text { Co-Director and FLEGT VPA Facilitator }\end{array}$ \\
\hline Norwegian Embassy & $\begin{array}{l}\text { Hege Karsti Ragnhildstveit } \\
\text { Counsellor }\end{array}$ \\
\hline Telapak & $\begin{array}{l}\text { Albert Hasudungan } \\
\text { Researcher/Staff of Forest Division }\end{array}$ \\
\hline Transparency International & $\begin{array}{l}\text { Hans Porada } \\
\text { Research Coordinator Asia Pacific Forest Governance Integrity } \\
\text { Centre }\end{array}$ \\
\hline UN Office on Drugs and Crime & $\begin{array}{l}\text { Ajit Joy } \\
\text { Country Manager }\end{array}$ \\
\hline UN Office on Drugs and Crime & $\begin{array}{l}\text { Novriady } \\
\text { Consultant }\end{array}$ \\
\hline
\end{tabular}




Indonesia has committed to reducing its emissions from land use, land use change and forestry by $26 \%$ by 2020 . One way the country plans to meet this target is by reducing its emissions from deforestation and forest degradation through the REDD+ mechanism. By implementing REDD+, Indonesia will become eligible to receive financial payments based on forest carbon credits. A substantial amount of Indonesia's carbon emissions are caused by deforestation and forest degradation from land conversion activities, forest fires and illegal logging. Illegal logging has significant impact as a driver of deforestation. Therefore, initiatives to curb illegal logging will have to form a central part of any emission reduction strategy. REDD+ has the potential to help reduce illegal logging activities by creating financial incentives to encourage compliance with the law, changes in behaviour and wider governance reforms.

Since 2001, several initiatives in Indonesia have attempted to address the problem of illegal logging. These include international initiatives such as the Forest Law Enforcement, Governance and Trade (FLEGT) process; bilateral agreements between Indonesia and major importers of timber; and market instruments such as timber certification. National initiatives include joint security sweeps to combat illegal logging, anti-money laundering approaches to tackle illegal finance in the sector and the expansion of timber plantations to increase the supply of timber.

This working paper explores ways in which the ongoing design of REDD+ mechanisms and institutions can benefit from these experiences. 